Prepared in cooperation with the Triangle Area Water Supply Monitoring Project Steering Committee

\title{
Triangle Area Water Supply Monitoring Project, October 1988 through September 2001, North Carolina-Description of the Water-Quality Network, Sampling and Analysis Methods, and Quality-Assurance Practices
}

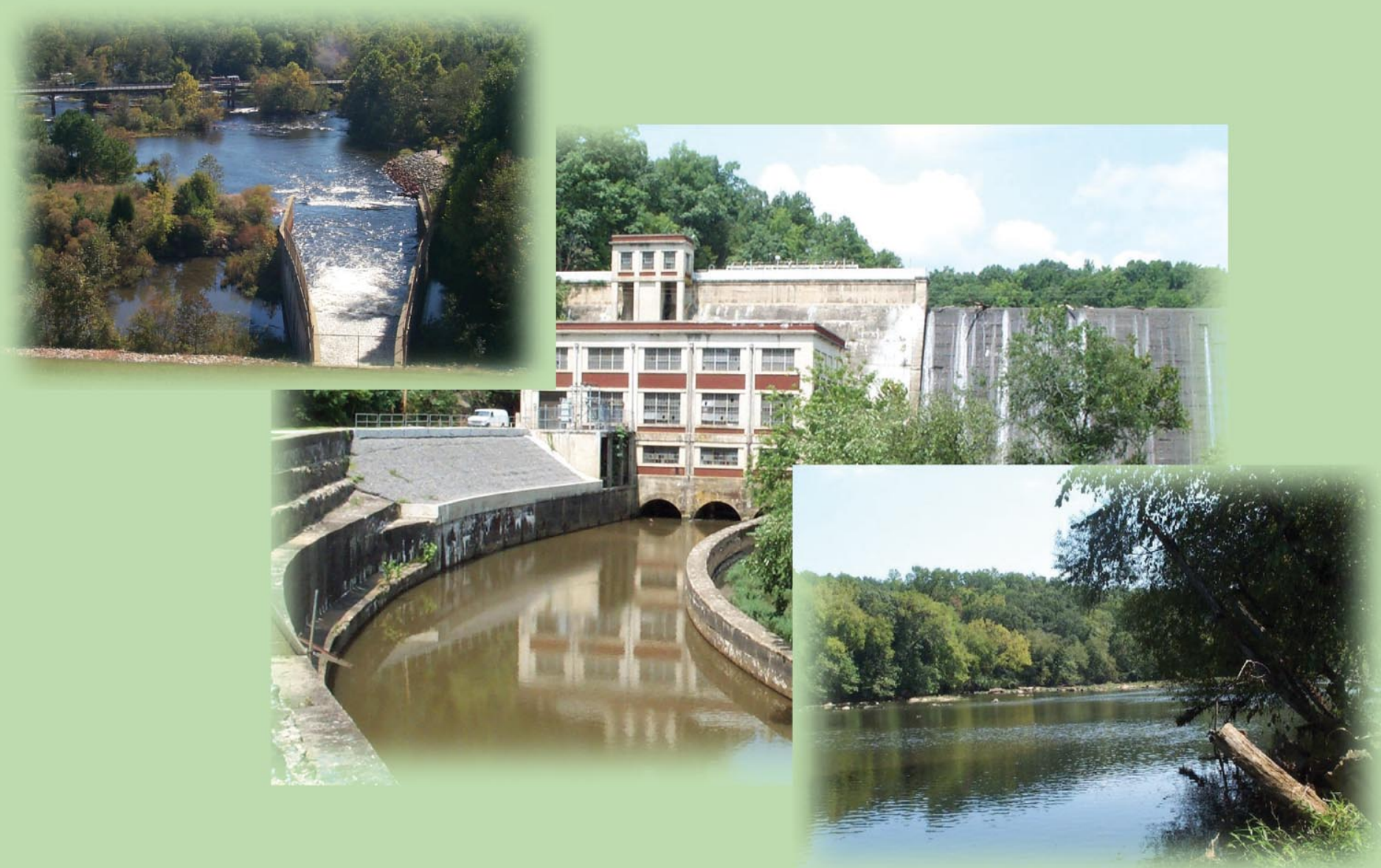

Open-File Report 2004-1278

U.S. Department of the Interior

U.S. Geological Survey 
Cover photographs (from U.S. Geological Survey, Raleigh Field Office files)

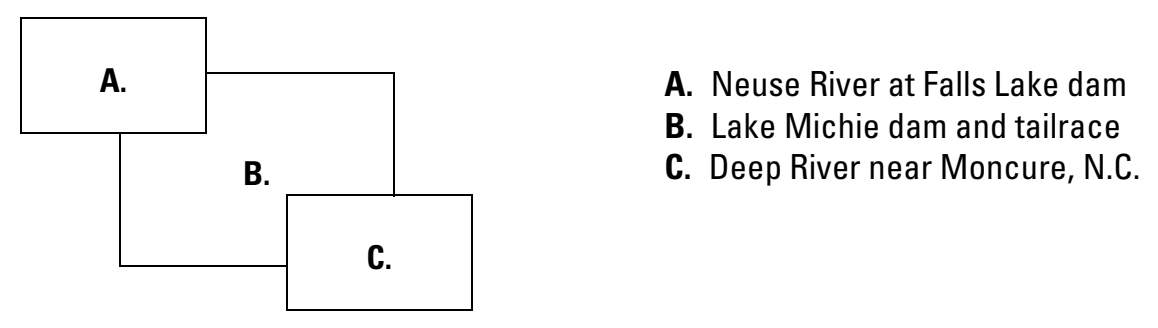




\section{Triangle Area Water Supply Monitoring Project, October 1988 through September 2001, North Carolina-Description of the Water-Quality Network, Sampling and Analysis Methods, and Quality-Assurance Practices}

By Carolyn J. Oblinger

Prepared in cooperation with the

Triangle Area Water Supply Monitoring Project Steering Committee

Open-File Report 2004-1278 


\title{
U.S. Department of the Interior Gale A. Norton, Secretary
}

\author{
U.S. Geological Survey \\ Charles G. Groat, Director
}

\section{U.S. Geological Survey, Reston, Virginia: 2004}

For sale by U.S. Geological Survey, Information Services

Box 25286, Denver Federal Center

Denver, CO 80225

For more information about the USGS and its products:

Telephone: 1-888-ASK-USGS

World Wide Web: http://www.usgs.gov/

Any use of trade, product, or firm names in this publication is for descriptive purposes only and does not imply endorsement by the U.S. Government.

Although this report is in the public domain, permission must be secured from the individual copyright owners to reproduce any copyrighted materials contained within this report. 


\section{Contents}



\section{Figures}

1-2. Maps showing locations of

1. Triangle Area Water Supply Monitoring Project study area in North Carolina and locations of major municipal water supplies and wastewater-treatment facilities........2

2. Monitoring sites in the Triangle Area Water Supply Monitoring Project, North Carolina .......7

3. Selected water-quality and suspended-sediment samplers used in streams and rivers for the Triangle Area Water Supply Monitoring Project, North Carolina ..... 
4. Lake samplers used for the Triangle Area Water Supply Monitoring Project in

North Carolina

5. Comparison of streamflow durations from long-term streamflow record with durations for sampled streamflow conditions .

6. Concentrations of selected major ions in trip and equipment blanks during the period of study for the Triangle Area Water Supply Monitoring Project in North Carolina

7. Concentrations of selected nutrients in equipment and trip blanks during the period of study for the Triangle Area Water Supply Monitoring Project in North Carolina

8. Concentrations of selected metals and trace elements in equipment and trip blanks during the period of study for the Triangle Area Water Supply Monitoring Project in North Carolina

9. Distribution of concentrations of calcium, magnesium, nitrate, orthophosphate, and silica in equipment blanks and trip blanks for the Triangle Area Water Supply Monitoring Project in North Carolina

10. Distribution of dissolved concentrations of aluminum, cadmium, chromium, copper, iron, manganese, nickel, lead, and zinc in equipment blanks and trip blanks for the Triangle Area Water Supply Monitoring Project in North Carolina

11-17. National Water Quality Laboratory control charts from the U.S. Geological Survey Inorganic Blind Sample Project showing the distribution of concentrations and trends in deviations for water years 1989-2001 from double-blind sample concentrations of:

11. Dissolved nitrite plus nitrate, total and dissolved organic nitrogen plus ammonia, and ammonia. 34

12. Dissolved orthophosphate and total and dissolved phosphorus .................... 35

13. Silica, fluoride, sulfate, and chloride......................................... 36



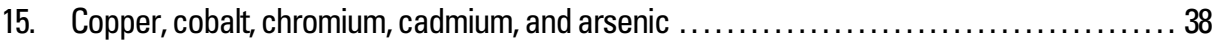

16. Nickel, molybdenum, manganese, lead, and iron. .............................. 39

17. Mercury, selenium, aluminum, zinc, and silver .............................. 40

\section{Tables}

1. Municipalities and organizations providing funding and membership to the Triangle Area Water Supply Monitoring Project Steering Committee in North Carolina ........................

2. Water-quality sampling sites in the Triangle Area Water Supply Monitoring Project, North Carolina

3. Water years and phases during which each water-quality site was active in the Triangle Area Water Supply Monitoring network in North Carolina

4. Water supplies included in the Triangle Area Water Supply Monitoring Project network in North Carolina

5. Sample schedules, bottle requirements, and preservation of samples analyzed at the U.S. Geological Survey National Water Quality Laboratory

6. North Carolina Division of Water Quality sampling schedule and analytical methods for sites in the Triangle Area Water Supply Monitoring Project

7. Inorganic constituents and physical properties analyzed by the U.S. Geological Survey National Water Quality Laboratory for the Triangle Area Water Supply Monitoring Project, and the methods used for sample analyses

8. Synthetic organic constituents analyzed by the U.S. Geological Survey National Water Quality Laboratory for the Triangle Area Water Supply Monitoring Project, and the methods used for sample analysis 
9. Status of electronic storage of unit-value data for water years 1989-2001 in the U.S. Geological Survey National Water Information System database for the Triangle Area Water Supply Monitoring Project in North Carolina

10. Numbers and types of blank samples collected for the Triangle Area Water Supply Monitoring Project in North Carolina, 1988-2001.

11. Results of analyses of de-ionized water produced in the U.S. Geological Survey North Carolina District office....

12. The distribution of concentrations in equipment and trip blank samples and the minimum, median, and maximum values of environmental samples

13. The percentage of blank samples that were analyzed for metals and trace elements with

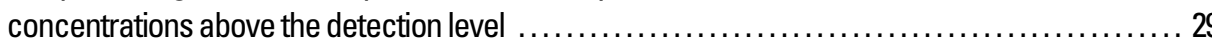

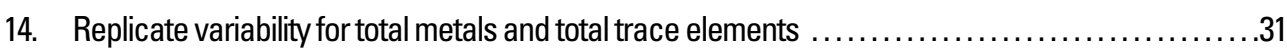

15. Replicate variability for physical measurements, major ions, nutrients, and chlorophyll .......... 33

\section{Appendix Tables (on CD inside back cover)}

A1. Site statistics for inorganic constituent concentrations in samples collected and analyzed by the U.S. Geological Survey.

A2. Site statistics for organic constituent concentrations in samples collected and analyzed by the U.S. Geological Survey.

A3. Environmental water-quality data and quality-control data collected by the U.S. Geological Survey for the Triangle Area Water Supply Monitoring Project between October 1, 1988, and September 30, 2001. 


\section{Conversion Factors, Definitions, and Acronyms and Abbreviations}

\begin{tabular}{|c|c|c|}
\hline Multiply & By & To obtain \\
\hline \multicolumn{3}{|c|}{ Length } \\
\hline foot $(\mathrm{ft})$ & 0.3048 & meter $(\mathrm{m})$ \\
\hline mile (mi) & 1.609 & kilometer (km) \\
\hline \multicolumn{3}{|c|}{ Area } \\
\hline acre & 0.4047 & hectare (ha) \\
\hline square mile $\left(\mathrm{mi}^{2}\right)$ & 2.590 & square kilometer $\left(\mathrm{km}^{2}\right)$ \\
\hline \multicolumn{3}{|c|}{ Volume } \\
\hline cubic foot $\left(\mathrm{ft}^{3}\right)$ & 0.02832 & cubic meter $\left(\mathrm{m}^{3}\right)$ \\
\hline \multicolumn{3}{|c|}{ Flow rate } \\
\hline acre-foot per day (acre-ft/d) & 0.01427 & cubic meter per second $\left(\mathrm{m}^{3} / \mathrm{s}\right)$ \\
\hline acre-foot per year (acre-ft/yr) & 1,233 & cubic meter per year $\left(\mathrm{m}^{3} / \mathrm{yr}\right)$ \\
\hline acre-foot per year (acre-ft/yr) & 0.001233 & cubic hectometer per year $\left(\mathrm{hm}^{3} / \mathrm{yr}\right)$ \\
\hline foot per second (ft/s) & 0.3048 & meter per second $(\mathrm{m} / \mathrm{s})$ \\
\hline cubic foot per second $\left(\mathrm{ft}^{3} / \mathrm{s}\right)$ & 0.02832 & cubic meter per second $\left(\mathrm{m}^{3} / \mathrm{s}\right)$ \\
\hline million gallons per day (Mgal/d) & 0.04381 & cubic meter per second $\left(\mathrm{m}^{3} / \mathrm{s}\right)$ \\
\hline \multicolumn{3}{|c|}{ Mass } \\
\hline pound, avoirdupois (lb) & 0.4536 & kilogram (kg) \\
\hline
\end{tabular}

Horizontal coordinate information is referenced to the North American Datum of 1983 (NAD 83).

Temperature in degrees Celsius $\left({ }^{\circ} \mathrm{C}\right)$ can be converted to degrees Fahrenheit $\left({ }^{\circ} \mathrm{F}\right)$ as follows:

$$
{ }^{\circ} \mathrm{F}=\left(1.8 x^{\circ} \mathrm{C}\right)+32
$$

Specific conductance is given in microsiemens per centimeter at 25 degrees Celsius $\left(\mu \mathrm{S} / \mathrm{cm}\right.$ at $\left.25^{\circ} \mathrm{C}\right)$.

Concentrations of chemical constituents in water are given in this report either in milligrams per liter (mg/L) or micrograms per liter $(\mu \mathrm{g} / \mathrm{L})$. Liter $(\mathrm{L})$ is a metric unit of volume equal to 2.1134 liquid pints.

Water year, as referred to in this report, is the period October 1 to September 30 and is identified by the calendar year in which the period ends. 


\section{Acronyms and Abbreviations}

$\begin{aligned} \text { DWO } & \text { North Carolina Division of Water Quality } \\ \text { ECD } & \text { electron capture detector } \\ \text { EWI } & \text { equal-width increment } \\ \text { FID } & \text { flame ionization detector } \\ \text { FISP } & \text { Federal Interagency Sedimentation Project } \\ \text { FPD } & \text { flame photometric detector } \\ \text { GC } & \text { gas chromatography } \\ \text { GC/FID } & \text { gas chromatography with flame ionization detector } \\ \text { HPLC } & \text { high-performance liquid chromatography } \\ \text { IBSP } & \text { Inorganic Blind Sample Project } \\ \text { mL } & \text { milliliter } \\ \text { mm } & \text { millimeter } \\ \text { MPV } & \text { most probable value } \\ \text { MS } & \text { mass spectrometry } \\ \text { NDWRF } & \text { North Durham Water Reclamation Facility } \\ \text { NWIS } & \text { USGS National Water Information System } \\ \text { NWOL } & \text { National Water Quality Laboratory } \\ \text { OBSP } & \text { Organic Blind Sample Project } \\ \text { OWASA } & \text { Orange Water and Sewer Authority } \\ \text { PCB } & \text { polychlorinated biphenyls } \\ \text { PCN } & \text { polychlorinated napthalene } \\ \text { QAS } & \text { Ouality Assurance Section of the NWOL } \\ \text { TJCOG } & \text { Triangle J Council of Governments } \\ \text { USGS } & \text { U.S. Geological Survey } \\ & \\ & \end{aligned}$




\title{
Triangle Area Water Supply Monitoring Project, October 1988 through September 2001, North Carolina- Description of the Water-Quality Network, Sampling and Analysis Methods, and Quality-Assurance Practices
}

\author{
By Carolyn J. Oblinger
}

\section{Abstract}

The Triangle Area Water Supply Monitoring Project was initiated in October 1988 to provide long-term water-quality data for six area water-supply reservoirs and their tributaries. In addition, the project provides data that can be used to determine the effectiveness of large-scale changes in water-resource management practices, document differences in water quality among water-supply types (large multiuse reservoir, small reservoir, run-of-river), and tributary-loading and in-lake data for water-quality modeling of Falls and Jordan Lakes. By September 2001, the project had progressed in four phases and included as many as 34 sites (in 1991). Most sites were sampled and analyzed by the U.S. Geological Survey. Some sites were already a part of the North Carolina Division of Water Quality statewide ambient water-quality monitoring network and were sampled by the Division of Water Quality. The network has provided data on streamflow, physical properties, and concentrations of nutrients, major ions, metals, trace elements, chlorophyll, total organic carbon, suspended sediment, and selected synthetic organic compounds.

Project quality-assurance activities include written procedures for sample collection, record management and archive, collection of field quality-control samples (blank samples and replicate samples), and monitoring the quality of field supplies. In addition to project quality-assurance activities, the quality of laboratory analyses was assessed through laboratory quality-assurance practices and an independent laboratory quality-control assessment provided by the U.S. Geological Survey Branch of Quality Systems through the Blind Inorganic Sample Project and the Organic Blind Sample Project.

\section{Introduction}

The Triangle Area Water Supply Monitoring Project was initiated in October 1988 in response to concern about the effects of increasing growth in the Triangle Area of North Carolina on the quality of drinking-water resources (fig. 1). The Triangle Area in the central North Carolina Piedmont includes the municipalities of Raleigh, Cary, Durham, and Chapel Hill. In 1988, two impoundment projects had been completed to provide new drinking-water supplies in the Triangle Area-the B. Everett Jordan and Falls of the Neuse Reservoirs (hereafter referred to as Jordan Lake and Falls Lake, respectively), and it was recognized that water supplies must be protected. The initial goal of the project was to collect water-quality data for six water-supply reservoirs and their tributaries in the Triangle Area. Some tributaries also are run-of-river water supplies. These water supplies were selected because they provide about 95 percent of the public surface-water supply for the area.

When initiated, the project objectives were to

- Expand the existing database for synthetic-organic chemicals and supplement the existing nutrient and trace-metal database so that long-term trends can be detected in major water supplies;

- Provide data that can be used to determine if large-scale changes in management practices are effective in producing improvements in water quality;

- Document spatial differences among water supplies and differences in water quality based on the source of water (large multiuse reservoir, small reservoir, and run-of-river); and

- Provide tributary loading and in-lake data for predictive water-quality models for Falls and Jordan Lakes. 




COUNTIES IN THE STUDY AREA IN THE PIEDMONT PROVINCE, NORTH CAROLINA

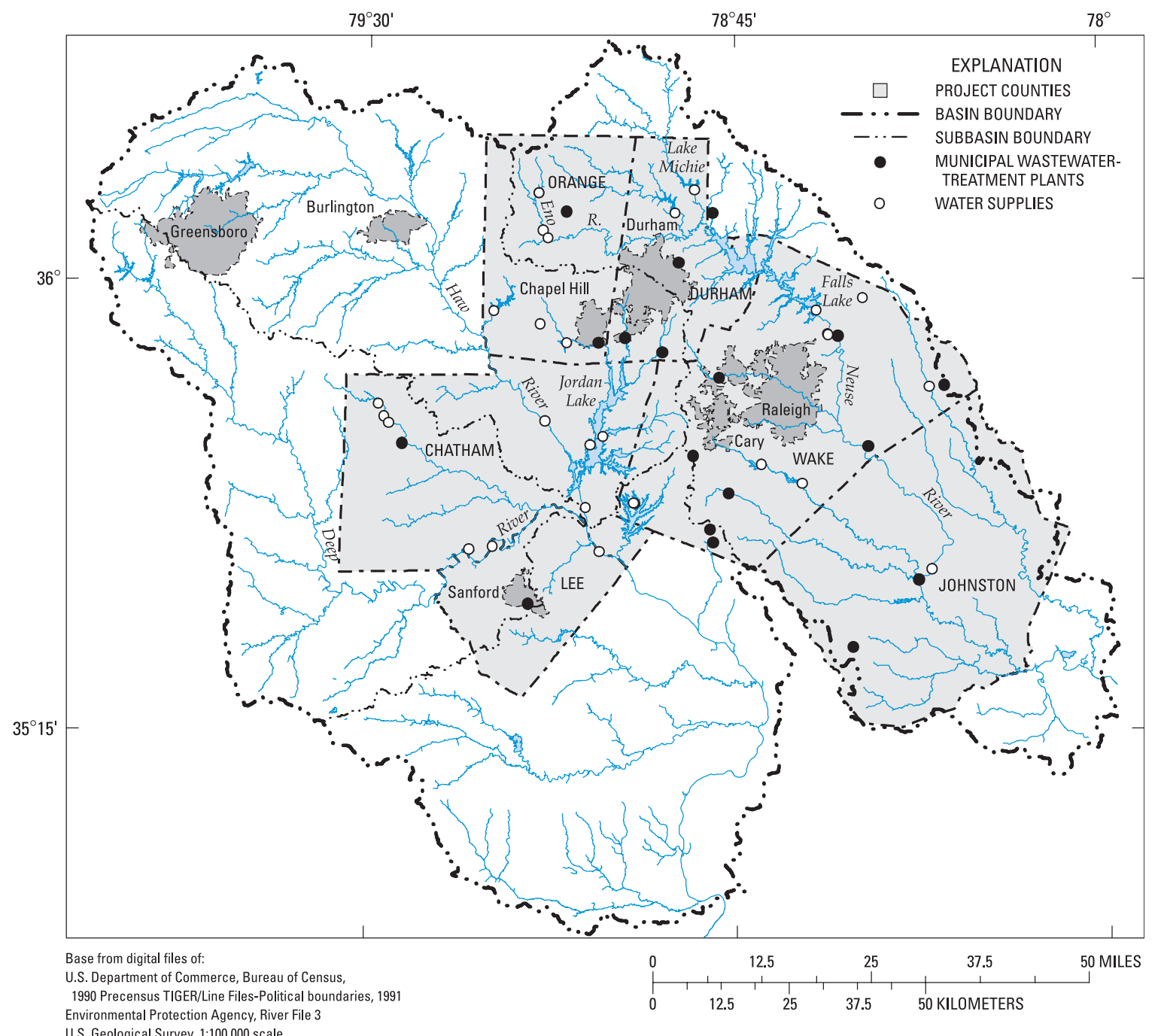

Figure 1. Triangle Area Water Supply Monitoring Project study area in North Carolina and locations of major municipal water supplies and wastewater-treatment facilities. 
Funding for the project has been provided by a consortium of municipalities and organizations with interest in drinkingwater quality (table 1 ) and by the USGS. The consortium, which provides 50 percent of the project funding, was formally organized through an interagency agreement as the Triangle Area Water Supply Monitoring Project Steering Committee (hereafter referred to as the Steering Committee). The Triangle J Council of Governments (TJCOG) manages the project on behalf of the Steering Committee. The USGS provides the remaining 50 percent of project funding.

Table 1. Municipalities and organizations providing funding and membership to the Triangle Area Water Supply Monitoring Project Steering Committee in North Carolina.

\begin{tabular}{lc}
\hline \multicolumn{1}{c}{$\begin{array}{c}\text { Participants } \\
\text { (locations shown in fig. 2) }\end{array}$} & $\begin{array}{c}\text { Period of } \\
\text { participation } \\
\text { through 2002 }\end{array}$ \\
\hline Town of Apex & $1988-$ continuing \\
Town of Cary & $1988-$ continuing \\
Chatham County & $1988-$ continuing \\
City of Durham & $1988-$ continuing \\
Orange County & $1988-$ continuing \\
OWASA (Towns of Chapel Hill and Carrboro) & $1988-$ continuing \\
Town of Hillsborough & $1988-$ continuing \\
Town of Pittsboro & $1988-1992$ \\
City of Raleigh & $1988-1995$ \\
Town of Sanford & $1988-1999$ \\
Town of Smithfield & $1988-1995$ \\
\hline
\end{tabular}

${ }^{\mathrm{a} O r a n g e}$ (County) Water and Sewer Authority.

Included in the study were sites that were routinely sampled by the North Carolina Department of Environment and Natural Resources, Division of Water Quality (DWQ), as part of the statewide ambient water-quality monitoring network. The DWQ sites selected for inclusion in the project network generally were located downstream from municipal wastewater discharges on tributaries to the area's raw-water supplies (table 2; fig. 2). To complete the Triangle Area Water-Supply Monitoring Project network, additional sites were established on lake and run-ofriver raw-water supplies and their tributaries. These sites are sampled by the U.S. Geological Survey (USGS).

Expectations expressed in 1988 about growth in the Triangle Area have been realized. Based on census records, the population of the Metropolitan Statistical Area, defined by the U.S. Office of Management and Budget as Chatham, Durham, Franklin, Johnston, Orange, and Wake Counties, was about 860,000 in 1990 (North Carolina State Data Center, 2002a, b). Between 1990 and 2000, the area grew by 38 percent. Between 2000 and 2010, the area is projected to grow by another 29 percent, bringing the total population of the area to about
1,540,000. As a consequence of population growth, land use in the Triangle Area has changed from forest and agriculture to urban and suburban.

\section{Purpose and Scope}

This report documents the history of the first four phases of the Triangle Area Water Supply Monitoring Project, including the scope, data-collection methods, laboratory analytical methods, and quality-assurance practices. The report documents sample-collection and processing methods for samples collected by the USGS and documents sample-analysis methods for samples analyzed by the USGS National Water Quality Laboratory. Summaries of stream- and lake-sample analyses (Appendixes A1, A2) and analyses of quality-control samples collected between October 1988 and September 2001 are presented. Quality-control data include blank samples and sample replicates that were collected to monitor the potential contamination of samples from such factors as sampling technique, sampling equipment and cleaning techniques, sample processing, and sample transport and shipping. A database containing USGS environmental and quality-control data and DWQ water-quality data collected from October 1988 through September 2001 also is included (Appendix A3; appendix tables are on a compact disc (CD) inside the back cover).

\section{Project History}

The project has consisted of four phases since beginning in October 1988. The basic objectives for each phase are those listed in the Introduction. In addition to these objectives, each phase had a unique supplemental area of focus for water quality. A description of each phase, including the supplemental work unique to each phase, follows. In all phases, the North Carolina DWQ collected samples at DWQ ambient water-quality monitoring sites within the network according to the frequency established for the State program. In phase I, the DWQ (then named the Division of Environmental Management) also sampled Falls and Jordan Lakes.

The first phase lasted for 3 years, from October 1988 through September 1991 (table 3). The sampling network consisted of 31 sites (table 2). Of these, 9 sites were located near stream or lake water supplies, 7 were located below wastewater discharges, and 15 were either lake or tributary sites (table 2). In general, the USGS sampled the tributary sites and small reservoirs (17 sites); the DWQ, as part of the statewide ambient water-quality monitoring network, sampled Falls and Jordan Lakes and sites below wastewater-treatment facilities (14 sites). Stream sites were sampled once per month. Lake sites were sampled five times per year. In addition, the USGS sampled each site three times per year for analysis of synthetic organic compounds.

During phase I, several adjustments were made to the network (table 3). The Eno River site at Hillsborough (site 1, Lake Ben Johnson) was moved downstream after the first year 
Table 2. Water-quality sampling sites in the Triangle Area Water Supply Monitoring Project, North Carolina.

[Sites that were in the original network, beginning in 1988, are shaded; USGS, U.S. Geological Survey; site type: I, intake site; W, site below wastewater discharge; T, tributary site; L, in-lake site; Q, discharge only site; WY, water year (defined as the period from October 1 through September 30 and identified by the calendar year in which the period ends); NA, not applicable; cont., continuous through the 2001 water year; DWQ, North Carolina Division of Water Quality; SR, secondary road]

\begin{tabular}{|c|c|c|c|c|c|c|c|c|}
\hline \multirow{2}{*}{$\begin{array}{c}\text { Site } \\
\text { number } \\
\text { (fig. 2) }\end{array}$} & \multirow{2}{*}{$\begin{array}{l}\text { USGS station } \\
\text { number }\end{array}$} & \multirow[b]{2}{*}{ Site name and location in North Carolina } & \multirow[b]{2}{*}{ County } & \multirow{2}{*}{$\begin{array}{l}\text { Drainage } \\
\text { area, in } \\
\text { square } \\
\text { miles }\end{array}$} & \multirow{2}{*}{$\begin{array}{l}\text { Site } \\
\text { type }\end{array}$} & \multirow{2}{*}{$\begin{array}{c}\text { Routine } \\
\text { sampling } \\
\text { by }\end{array}$} & \multicolumn{2}{|c|}{ Period of record as of WY2002 } \\
\hline & & & & & & & Streamflow & $\begin{array}{l}\text { Water quality } \\
\text { (beginning 10/88) }\end{array}$ \\
\hline 1 & 0208491605 & Eno River at Hillsborough (initial site) & Orange & 60.4 & I & USGS & NA & $10 / 88-9 / 89$ \\
\hline 2 & 02085000 & Eno River at Hillsborough (replaced site 1) & Orange & 66.0 & I & USGS & $\begin{array}{l}\text { 10/27-9/71; } \\
\text { 10/85-cont. }\end{array}$ & 10/89-cont. \\
\hline 3 & 02085070 & Eno River near Durham & Durham & 141.0 & W & DWQ & 8/63-cont. & 10/88-cont. \\
\hline 4 & 02085079 & Eno River near Weaver & Durham & 148.0 & $\mathrm{~W}$ & USGS & NA & $10 / 88-9 / 99$ \\
\hline 5 & 0208521324 & Little River at SR1461 near Orange Factory & Durham & 78.2 & $\mathrm{~T}$ & DWQ & 9/61-cont. & 10/88-cont. \\
\hline 6 & 0208524845 & Little River Reservoir at dam near Bahama & Durham & 97.7 & I & USGS & NA & 10/88-cont. \\
\hline 7 & 0208524850 & Little River below dam near Fairntosh & Durham & 97.8 & $\mathrm{~T}$ & USGS & NA & $10 / 88-6 / 91$ \\
\hline 8 & 02085500 & Flat River at Bahama & Durham & 149.0 & $\mathrm{~T}$ & DWQ & $7 / 25-$ cont. & 10/88-cont. \\
\hline 9 & 02086490 & Lake Michie at dam near Bahama & Durham & 167.0 & I & USGS & NA & 10/88-cont. \\
\hline 10 & 02086500 & Flat River at dam near Bahama & Durham & 168.0 & $\mathrm{~T}$ & DWQ & 9/27-cont. ${ }^{\text {a }}$ & $10 / 88-3 / 93$ \\
\hline 11 & 02086624 & Knap of Reeds Creek near Butner & Granville & 43.0 & $\mathrm{~W}$ & DWQ & $10 / 82-9 / 95$ & $10 / 88-4 / 95$ \\
\hline 12 & 02086849 & Ellerbe Creek near Gorman & Durham & 21.9 & W & DWQ & $10 / 82-9 / 95$ & $10 / 88-4 / 95$ \\
\hline 13 & 02086920 & Falls Lake at I-85 near Redwood & Durham & 512 & $\mathrm{~L}$ & USGS & NA & $12 / 88-7 / 95$ \\
\hline 14 & 0208700780 & $\begin{array}{l}\text { Little Lick Creek above SR1814 near Oak } \\
\text { Grove }\end{array}$ & Durham & 10.1 & $\mathrm{~T}$ & DWQ & $10 / 82-9 / 95$ & $10 / 88-4 / 95$ \\
\hline 15 & 0208703650 & Falls Lake at N.C. 50 near Sandy Plain & Wake & 620 & $\mathrm{~L}$ & USGS & NA & $12 / 88-7 / 95$ \\
\hline
\end{tabular}


Table 2. Water-quality sampling sites in the Triangle Area Water Supply Monitoring Project, North Carolina.-Continued

[Sites that were in the original network, beginning in 1988, are shaded; USGS, U.S. Geological Survey; site type: I, intake site; W, site below wastewater discharge; T, tributary site; L, in-lake site; Q, discharge only site; WY, water year (defined as the period from October 1 through September 30 and identified by the calendar year in which the period ends); NA, not applicable; cont., continuous through the 2001 water year; DWQ, North Carolina Division of Water Quality; SR, secondary road]

\begin{tabular}{|c|c|c|c|c|c|c|c|c|}
\hline \multirow{2}{*}{$\begin{array}{c}\text { Site } \\
\text { number } \\
\text { (fig. 2) }\end{array}$} & \multirow[b]{2}{*}{$\begin{array}{l}\text { USGS station } \\
\text { number }\end{array}$} & \multirow[b]{2}{*}{ Site name and location in North Carolina } & \multirow[b]{2}{*}{ County } & \multirow{2}{*}{$\begin{array}{c}\text { Drainage } \\
\text { area, in } \\
\text { square } \\
\text { miles }\end{array}$} & \multirow[b]{2}{*}{$\begin{array}{l}\text { Site } \\
\text { type }\end{array}$} & \multirow{2}{*}{$\begin{array}{c}\text { Routine } \\
\text { sampling } \\
\text { by }\end{array}$} & \multicolumn{2}{|c|}{ Period of record as of WY2002 } \\
\hline & & & & & & & Streamflow & $\begin{array}{l}\text { Water quality } \\
\text { (beginning 10/88) }\end{array}$ \\
\hline 16 & 0208708905 & Falls Lake at N.C. 98 near Bayleaf & Wake & 704 & $\mathrm{~L}$ & USGS & NA & $12 / 88-7 / 95$ \\
\hline 17 & 0208718195 & Falls Lake above dam at Falls ${ }^{\mathrm{b}}$ & Wake & 771 & I & USGS & NA & $12 / 88-7 / 95$ \\
\hline 18 & 02087183 & Neuse River near Falls & Wake & 771 & $\mathrm{~T}$ & DWQ & 6/70-cont. & $12 / 88-9 / 95$ \\
\hline 19 & 02087500 & Neuse River near Clayton & Johnston & 1,150 & Q & NA & 8/27-cont. & NA \\
\hline 20 & 02087570 & Neuse River at Smithfield & Johnston & 1,206 & I & USGS & $10 / 70-9 / 91$ & $10 / 88-9 / 95$ \\
\hline 21 & 02087580 & Swift Creek near Apex & Wake & 21 & $\mathrm{~T}$ & USGS & NA & $10 / 89-7 / 95$ \\
\hline 22 & 02087701 & Lake Benson at dam near Garner & Wake & 67.0 & I & USGS & NA & $10 / 89-6 / 95$ \\
\hline 23 & 02096846 & Cane Creek near Orange Grove & Orange & 7.5 & $\mathrm{~T}$ & USGS & 11/88-cont. & 10/88-cont. \\
\hline 24 & 0209684980 & Cane Creek reservoir at dam near White Cross & Orange & 31.4 & I & USGS & NA & 4/89-cont. \\
\hline 25 & 02096960 & Haw River near Bynum & Chatham & 1,275 & I & DWQ & 10/73-cont. & 10/88-cont. \\
\hline 26 & 0209719700 & $\begin{array}{l}\text { B.E. Jordan Lake, Haw River arm above B.E. } \\
\text { Jordan dam }\end{array}$ & Chatham & 1,296 & $\mathrm{~L}$ & USGS & NA & 12/88-cont. \\
\hline 27 & 02097314 & New Hope Creek near Blands & Durham & 75.9 & $\mathrm{~W}$ & DWQ & 10/82-cont. & $12 / 88-$ cont. \\
\hline 28 & 0209741955 & Northeast Creek at SR1100 near Genlee & Durham & 21.1 & W & DWQ & 10/82-cont. & $12 / 88-$ cont. \\
\hline 29 & 02097464 & Morgan Creek near White Cross & Orange & 8.4 & $\mathrm{~T}$ & USGS & 11/82-cont. & $10 / 88-$ cont. \\
\hline 30 & 0209749990 & University Lake at the dam near Chapel Hill & Orange & 30 & I & USGS & NA & 11/88-cont. \\
\hline
\end{tabular}


Table 2. Water-quality sampling sites in the Triangle Area Water Supply Monitoring Project, North Carolina.—Continued

[Sites that were in the original network, beginning in 1988, are shaded; USGS, U.S. Geological Survey; site type: I, intake site; W, site below wastewater discharge; T, tributary site; L, in-lake site; Q, discharge only site; WY, water year (defined as the period from October 1 through September 30 and identified by the calendar year in which the period ends);

NA, not applicable; cont., continuous through the 2001 water year; DWQ, North Carolina Division of Water Quality; SR, secondary road]

\begin{tabular}{|c|c|c|c|c|c|c|c|c|}
\hline \multirow{2}{*}{$\begin{array}{c}\text { Site } \\
\text { number } \\
\text { (fig. 2) }\end{array}$} & \multirow[b]{2}{*}{$\begin{array}{l}\text { USGS station } \\
\text { number }\end{array}$} & \multirow[b]{2}{*}{ Site name and location in North Carolina } & \multirow[b]{2}{*}{ County } & \multirow{2}{*}{$\begin{array}{c}\text { Drainage } \\
\text { area, in } \\
\text { square } \\
\text { miles }\end{array}$} & \multirow{2}{*}{$\begin{array}{l}\text { Site } \\
\text { type }\end{array}$} & \multirow{2}{*}{$\begin{array}{c}\text { Routine } \\
\text { sampling } \\
\text { by }\end{array}$} & \multicolumn{2}{|c|}{ Period of record as of WY2002 } \\
\hline & & & & & & & Streamflow & $\begin{array}{l}\text { Water quality } \\
\text { (beginning 10/88) }\end{array}$ \\
\hline 31 & 02097517 & Morgan Creek near Chapel Hill & Orange & 41 & Q & NA & $11 / 82-$ cont. & NA \\
\hline 32 & 02097521 & Morgan Creek near Farrington & Chatham & 45.6 & W & DWQ & NA & 12/88-cont. \\
\hline 33 & 0209768310 & Jordan Lake at buoy 12 at Farrington & Chatham & NA & $\mathrm{L}$ & USGS & NA & 8/92-cont. \\
\hline 34 & 0209771550 & Jordan Lake at buoy 9 near Farrington & Chatham & 250 & $\mathrm{~L}$ & USGS & NA & $10 / 88-9 / 92$ \\
\hline 35 & 0209782520 & White Oak Creek at Green Level & Wake & 6.97 & $\mathrm{~T}$ & USGS & 10/99-cont. & 9/99-cont. \\
\hline 36 & 0209799150 & B.E. Jordan Lake above U.S. 64 at Wilsonville & Chatham & NA & I & USGS & NA & 7/91-cont. \\
\hline 37 & 0209801050 & $\begin{array}{l}\text { Jordan Lake at buoy } 7 \text { below U.S. } 64 \text { near } \\
\text { Griffins Crossroads }\end{array}$ & Chatham & NA & $\mathrm{L}$ & USGS & NA & $12 / 88-9 / 92$ \\
\hline 38 & 0209801100 & $\begin{array}{l}\text { B.E. Jordan Lake at Bells Landing near } \\
\text { Griffins Crossroads }\end{array}$ & Chatham & NA & I & USGS & NA & $\begin{array}{l}\text { 7/91-8/95; } \\
\text { 8/99-cont. }\end{array}$ \\
\hline 39 & 02098198 & $\begin{array}{l}\text { Haw River below B. Everett Jordan dam near } \\
\text { Moncure }\end{array}$ & Chatham & 1,689 & $\mathrm{~T}$ & DWQ & NA & $12 / 88-4 / 95$ \\
\hline 40 & 0210140200 & Deep River at Carbonton & Chatham & 1,026 & I & DWQ & NA & $1 / 93-9 / 96$ \\
\hline 41 & 0210215985 & Cape Fear River at N.C. 42 near Brickhaven & Chatham & 3,160 & I & USGS & NA & 10/88-cont. \\
\hline
\end{tabular}

${ }^{\mathrm{a}}$ Includes several multiyear breaks in the record

${ }^{\mathrm{b}}$ Formerly published as USGS station number 02087182. 




Figure 2. Monitoring sites in the Triangle Area Water Supply Monitoring Project, North Carolina. 
Table 3. Water years and phases during which each water-quality site was active in the Triangle Area Water Supply Monitoring network in North Carolina.

[Sites in bold are sampled primarily by the U.S. Geological Survey (USGS); SR, secondary road]

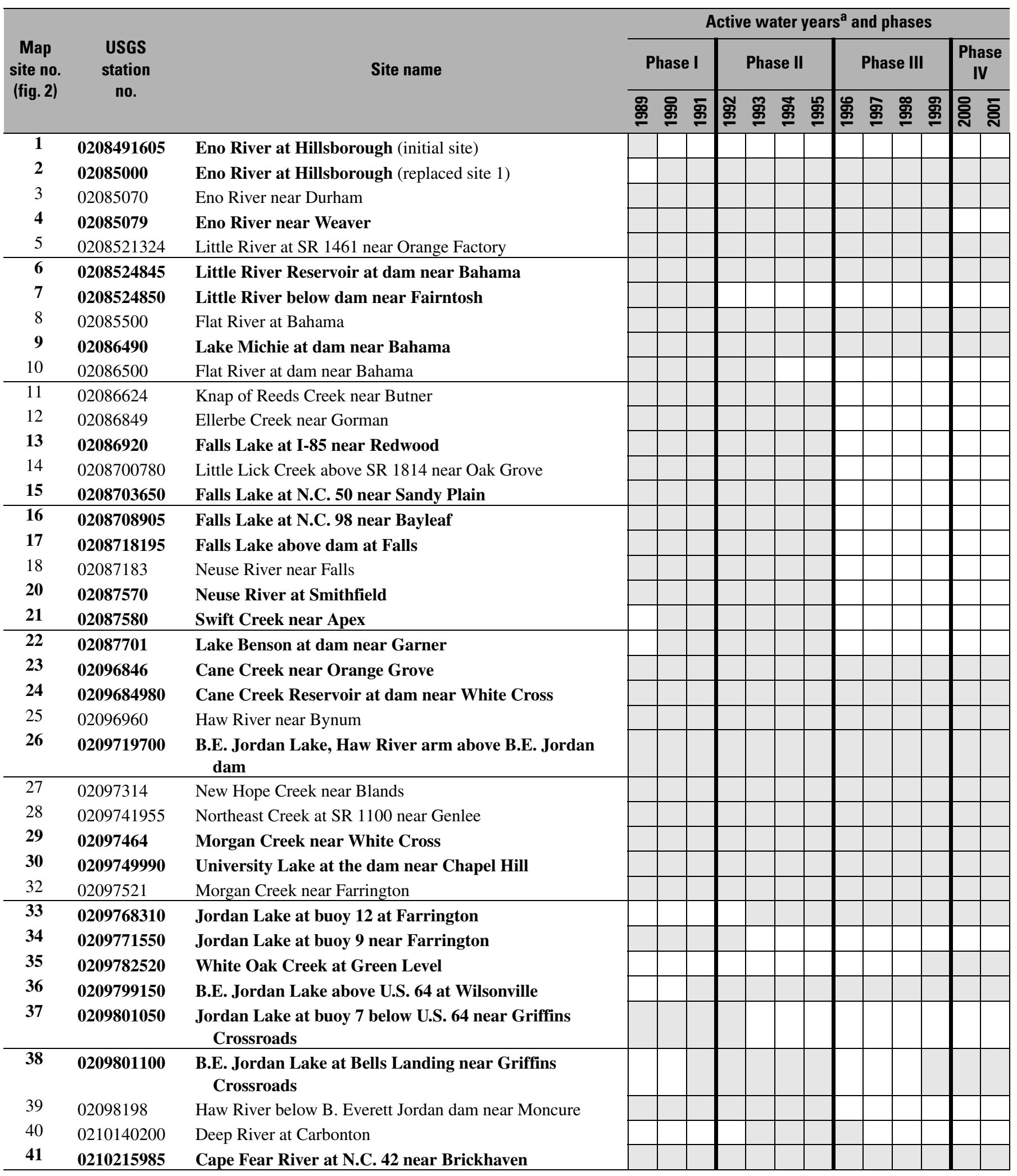

${ }^{\mathrm{a}}$ Water year is the period from October 1 through September 30 and is defined by the calendar year in which the period ends. 
(to site 2). Three more water-supply sites were added to the network in 1991 — Lake Benson (site 22, a potential water supply for Raleigh), Jordan Lake (site 36), and Swift Creek near Apex (site 21). In 1991, the DWQ reduced sampling at Falls and Jordan Lakes to once per year, and the USGS began sampling these sites the remaining four times per year as required to meet the project objectives. The unique focus of phase I was to identify the occurrence of synthetic organic compounds in water at the network sites and in Haw River bed sediments.

Phase II of the project began in October 1991 and continued for 4 years through September 1995. Based on the preliminary analysis of the data, the network was adjusted again. The sites downstream from Lake Michie and Little River Reservoir (sites 10 and 7) were discontinued because water quality in the stream channel directly downstream from the lake did not differ substantially from water quality measured in the lakes near the dam. Jordan Lake sites 37 and 34 at buoys 7 and 9 , respectively, were discontinued, and site 33 at buoy 12 was added so that the sampling sites in Jordan Lake were distributed among the four segments of Jordan Lake. Also, Deep River at Carbonton (site 40), a water-supply site, was added to the network. In addition to continued routine sample collection, phase II objectives focused on determining if the occurrence of pesticides identified in phase I downstream from municipal wastewater discharges originated from raw wastewater or from sources upstream from the wastewater-discharge point.

Phase III began in October 1995 and continued through June 1999. The City of Raleigh and the Town of Smithfield withdrew funding from the project at the start of phase III. To accommodate the decreased funding, sites located in the Neuse River watershed that were in or downstream from Falls Lake were discontinued as was the Jordan Lake site at Bells Landing (site 38) and Deep River at Carbonton (site 40). In addition, sampling frequency at the remaining sites was decreased from monthly to semimonthly for stream sites and from five times per year to four times per year for lake sites. The special focus of phase III was to assess the occurrence of Cryptosporidium parvum oocyts and Giardia lamblia cysts in raw-water supplies. Samples were collected from selected sites in the existing network. Sample collection also focused on the collection of water-quality samples during high-flow events.

Phase IV began in July 1999 and continued through June 2003. In this phase, two sites were added - site 35 was added on White Oak Creek at Green Level, a tributary to Jordan Lake, and site 38 was reactivated on Jordan Lake at Bells Landing, the general location of a future water supply. Lake sampling was expanded to include samples for analysis of iron, manganese, and nutrient concentrations at multiple depths. The focus of the phase IV objectives was on increasing the number of high-flow samples that were collected to provide data for use in more accurately estimating constituent load.

Data collected for the Triangle Area Water Supply Monitoring Project have been published annually in USGS data reports for North Carolina (Ragland and others, 1990, 1991; Barker and others, 1992; Gunter and others, 1993; Barker and others, 1994; Ragland and others, 1995-2003). Garrett and others (1994) published data through 1992. Data collected by the USGS are available to the public in the USGS National Water Information System (NWIS) water-quality database. Interpretations of the data have been reported in unpublished reports by the Triangle Area Water Supply Monitoring Project Steering Committee and in published reports of the USGS (Childress and Treece, 1996; Childress and Bathala, 1997).

\section{Study Area}

The study area is located within a six-county region in the upper Neuse and Cape Fear River basins in the Piedmont Province of central North Carolina (fig. 1). The drainage area of the Neuse River at Smithfield, the downstream terminus of the study area in the Neuse River basin, is 1,206 square miles $\left(\mathrm{mi}^{2}\right)$. The Cape Fear River is formed by the confluence of the Haw $\left(1,695 \mathrm{mi}^{2}\right)$ and Deep $\left(1,441 \mathrm{mi}^{2}\right)$ Rivers downstream from Jordan Lake (fig. 2). The land use in much of the study area is forest or agricultural; however, the cities of Raleigh and Durham and towns of Cary, Chapel Hill, and Hillsborough have significant and growing urban and suburban land covers. The study area is described in more detail in Childress and Treece (1996).

Sampling sites were selected in 1988 to represent the major drinking-water supplies in the area and the major tributaries to the drinking-water supplies (table 2). In 1988, some tributary sites included in the network were being sampled routinely by the North Carolina DWQ as part of the statewide ambient water-quality monitoring network. These sites are identified in table 2. At some of the stream sites, continuous-recording streamflow gages were already established and funded by other agencies. Gages were installed at stream sites with no existing gage.

Twelve water supplies are included in the Triangle Area Water Supply Monitoring Project network (table 4). These raw water supplies are large multipurpose reservoirs (greater than 10,000 acres), small reservoirs (less than 1,000 acres), and runof-river supplies serving most of the population in the Triangle Area.

The city of Raleigh withdraws drinking water from Falls Lake. Backup water supplies for Raleigh are Lakes Wheeler, Benson, and Johnson. Only Lake Benson was included in this study. Drinking water for the town of Sanford is supplied by the Cape Fear River and for the town of Smithfield by the Neuse River.

The towns of Cary and Apex share a treatment plant that withdraws water from Jordan Lake. Treatment capacity was increased from 24 million gallons per day $(\mathrm{Mgal} / \mathrm{d})$ to $40 \mathrm{Mgal} / \mathrm{d}$ in 2002 (Town of Cary, 2002). Currently, public surface-water supplies serve less than 10 percent of Chatham County's population. Chatham County purchases treated water from Sanford, Siler City, and Goldston-Gulf Sanitary District and raw water from Cary/Apex. Goldston-Gulf withdraws water from the Deep River. 
Table 4. Water supplies included in the Triangle Area Water Supply Monitoring Project network in North Carolina.

[OWASA, Orange (County) Water and Sewer Authority]

\begin{tabular}{lllc}
\hline \multicolumn{1}{c}{ Raw-water supply } & \multicolumn{1}{c}{ Type of water supply } & \multicolumn{1}{c}{ Municipality or utility } & $\begin{array}{c}\text { Period in the } \\
\text { network through } \\
\text { water year 2001 }\end{array}$ \\
\hline Falls Lake & Large multipurpose reservoir & Raleigh & $1988-1995$ \\
Jordan Lake at U.S. 64 & Large multipurpose reservoir & Cary and Apex & $1988-2001$ \\
Jordan Lake at Bells Landing & Large multipurpose reservoir & Proposed Chatham County & $1991-2001$ \\
Lake Michie & Small reservoir & Durham & $1988-2001$ \\
Little River Reservoir & Small reservoir & Durham & $1988-2001$ \\
Neuse River at Smithfield & Run of river & Smithfield & $1988-1995$ \\
Lake Benson & Small reservoir & Raleigh (proposed) & $1989-1995$ \\
University Lake & Small reservoir & OWASA & $1988-2001$ \\
Cane Creek Reservoir & Small reservoir & OWASA & $1988-2001$ \\
Haw River near Bynum & Run of river & Pittsboro & $1988-2001$ \\
Cape Fear River near Brickhaven & Run of river & Sanford & $1988-2001$ \\
Deep River at Carbonton & Run of river & Goldston-Gulf Sanitary District & $1993-1996$ \\
(Lake Ben Johnson) Eno River ${ }^{\mathrm{a}}$ & Run-of-river reservoir & Hillsborough & $1988-2001$ \\
\hline
\end{tabular}

${ }^{a}$ Site was moved from the intake to a more suitable sampling location on the Eno River less than 2 miles downstream.

The city of Durham withdraws water from Lake Michie and Little River Reservoir, both in northeastern Durham County. The combined yield of these reservoirs is $43 \mathrm{Mgal} / \mathrm{d}$. The Orange Water and Sewer Authority (OWASA) is a nonprofit water and sewer utility that serves the towns of Chapel Hill and Carrboro. OWASA draws its water supply from University Lake and Cane Creek Reservoir. These two lakes can provide up to $15.1 \mathrm{Mgal} / \mathrm{d}$ for treatment (Orange Water and Sewer Authority, 2001). Water demand has doubled since 1977 and is expected to double again by 2050. The Quarry Reservoir, west of Carrboro, is available to OWASA for backup use but was not included in this study. Hillsborough is supplied by Lake Orange and Lake Ben Johnson, both impoundments of the Eno River near Hillsborough. Pittsboro is supplied by the Haw River.

Some of the tributaries to the raw-water supplies in the network receive discharges from municipal wastewatertreatment facilities (fig. 1). Among the largest of these are the South Durham Water Reclamation Facility, which discharges to New Hope Creek, and North Durham Water Reclamation Facility (NDWRF), which discharges to Ellerbe Creek. The NDWRF also receives sewage formerly sent to the Eno and Little Lick wastewater-treatment plants, which ceased operation in 1994. Together, these two Durham facilities discharge about $16 \mathrm{Mgal} / \mathrm{d}$. Other wastewater-treatment facilities include the Durham County Triangle Wastewater Treatment Facility, which discharges to Northeast Creek; OWASA's Mason Farms Wastewater Treatment Plant, which discharges about $8 \mathrm{Mgal} / \mathrm{d}$ to Morgan Creek; and Raleigh's Neuse River Wastewater Treatment Plant in southeast Raleigh, which discharges about $36 \mathrm{Mgal} / \mathrm{d}$ to the Neuse River.

\section{Sampling and Analytical Methods}

Because some project sites were sampled by the USGS and some were sampled by the North Carolina DWQ, methods of data collection and sample analysis differed. The DWQ samplecollection and analysis methods are not described in this report. The USGS sample-collection and analysis methods were in compliance with the USGS standard operating procedures as published in the USGS Techniques for Water-Resources Investigations, in USGS Open-File Reports documenting laboratory methods, and in unpublished USGS North Carolina District quality-assurance guidelines. These publications are referenced in the following sections of this report.

\section{Field Methods}

Field methods encompass sampling activities that take place at the field site, such as sample collection, processing and preservation of samples, and in-situ or onsite measurement of physical properties. USGS field protocols are contained in various published and unpublished USGS documents and memorandums (Guy and Norman, 1970; Office of Water Data Coordination, 1977; U.S. Geological Survey, 1997-present; Edwards and Glysson, 1999; North Carolina District QualityAssurance Plan for Water Quality, written commun., 2000). The North Carolina District quality-assurance plan for water-quality activities (North Carolina District Quality-Assurance Plan for Water Quality, written commun., 2000) and quality-assurance plan for surface-water activities (North Carolina District Quality-Assurance Plan for Surface Water, written commun., 1995) are updated approximately every 3 years. These plans 
provide guidance to USGS staff on water-quality and surfacewater field methods and include references to relevant USGS memorandums.

\section{Sample Collection}

At each stream site, dissolved oxygen and temperature were measured in situ. Specific conductance and $\mathrm{pH}$ were measured in situ or in the composited sample on site. Measurements were made according to USGS published and unpublished protocols (U.S. Geological Survey, 1997-present; North Carolina District Quality-Assurance Plan for Water Quality, written commun., 2000).

Samples were collected and processed according to standard USGS protocols in effect at the time of sample collection. A major revision in USGS protocols for collecting samples occurred in 1994 when new sample-handling techniques with less potential for sample contamination were introduced. The so called "parts-per-billion protocol" or "cleanhands protocol" was developed for the collection of samples containing low-level concentrations of trace elements and nutrients. These methods were published in the USGS National Field Manual (U.S. Geological Survey, 1997-present) and were adopted for use in this study.

\section{Streams}

At each stream site, measurements of dissolved oxygen, temperature, specific conductance, and $\mathrm{pH}$ were measured in situ or in the collected sample (except dissolved oxygen). Measurements were made electrometrically with individual meters or with a multiparameter data sonde. Alkalinity was measured at the time of sample collection using fixed-endpoint (to $\mathrm{pH} 4.5$ ) or incremental titration.

Stream samples usually were collected with depthintegrating isokinetic samplers (fig. 3) using equal-widthincrement (EWI) methods (Edwards and Glysson, 1999; Wilde and others, 1999a). The EWI method provides for collection of a sample that is representative of the average concentration in the stream cross section. Isokinetic samplers were designed by the Federal Interagency Sedimentation Project (FISP) to allow flowing water to enter the sampler nozzle at the same velocity as in the stream. Improved designs for water-quality samplers were introduced during the course of the project and were adopted as they became available.

For wadeable streams, the samplers that were used included the 22-pound (lb), plastic-coated, bronze DH-59 sampler with a 1-pint glass bottle that was used prior to about 1990 , and the 0.5-lb polypropylene DH-81 sampler with a 1-liter (L) polyethylene bottle (fig. 3). For wadeable streams, suspended-sediment samples were collected separately from the water-quality samples using an aluminum DH-48 (not pictured) or the DH-59 sampler with a pint-size glass bottle.

For streams too deep to wade, sampling was done from a bridge using a 22-lb, plastic-coated, bronze DH-76 sampler with a 1-quart glass bottle; a 75-1b, plastic-coated, bronze D-77 cable-suspended sampler with 1- or 3-L polyethylene bottle; or a 64-lb, plastic-coated, bronze D-95 sampler with a 1-L polyethylene bottle. Use of the DH-76 sampler for collection of water-quality samples was discontinued in about 1992. Use of the D-77 sampler for collection of water-quality samples was discontinued in about 1998. Suspended-sediment samples were collected separately from the water-quality samples by using a DH-76 or DH-59 sampler with a quart-size and pint-size glass bottle, respectively. All of the isokinetic samplers are fitted with nylon or Teflon nozzles. The DH-81, D-77, and D-95 samplers are designed so that the nozzle fits into a plastic or Teflon cap that threads directly onto the sample bottle, which minimizes contact between the sampler and the sampled water. Details about sampler design are provided in Wilde and others (1998b) and Edwards and Glysson (1999).

Isokinetic samplers are effective when stream velocity exceeds 1.5 feet per second (ft/s) and stream depth exceeds about 0.5 foot (ft; Wilde and others, 1998b). When stream velocity was less than $1.5 \mathrm{ft} / \mathrm{s}$ or depth was less than $0.5 \mathrm{ft}$, multiple subsamples were collected at equal widths in the stream cross section using a weighted bottle sampler (also called a sewage sampler) or bottles were filled directly by dipping them in the stream (dip method).

As multiple subsamples were collected as described above using isokinetic or weighted bottle samplers or the dip method, subsamples were composited in an 8-L plastic churn splitter before 1994 and in a modified 8-L plastic churn splitter after 1994 (Wilde and others, 1998b, Section 2.2.1A). The modifications to the churn splitter were designed to minimize the potential for atmospheric contamination to the sample and to improve the spigot mechanism to reduce the potential for contamination when the sample was withdrawn from the churn into the sample bottle.

Suspended-sediment samples were collected only at stream sites. Samples were collected by using the EWI methods described in Guy and Norman (1970) and Edwards and Glysson (1999) at multiple locations in the stream cross section.

Suspended-sediment subsamples were not composited onsite but were sent instead to the sediment laboratory in the individual bottles in which they were collected. Sample bottles were shipped to the sediment laboratory in crates without preservation.

Samples for analysis of total organic carbon and synthetic organic compounds could not be collected with the isokinetic samplers described above and could not be composited in a churn splitter because of potential contamination from plastic components in the samplers, bottles, and churn splitter. Instead, samples for analysis of total organic carbon and synthetic organic compounds were collected directly into baked-glass sample bottles using a weighted bottle sampler or the dip method of sample collection. These samples were collected at the center of flow in the stream. 


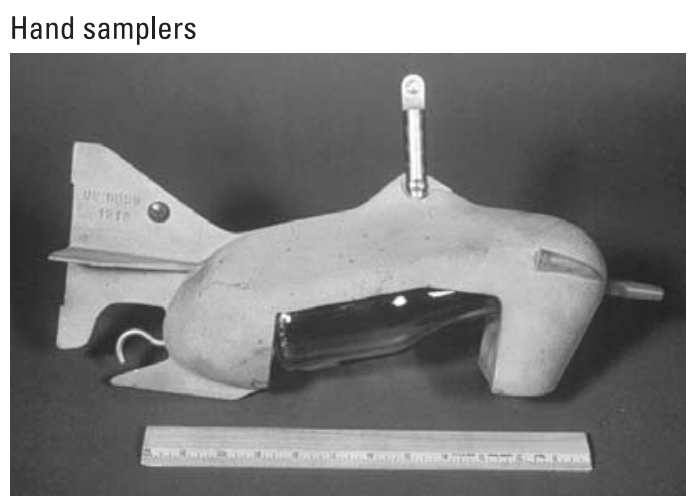

DH-59

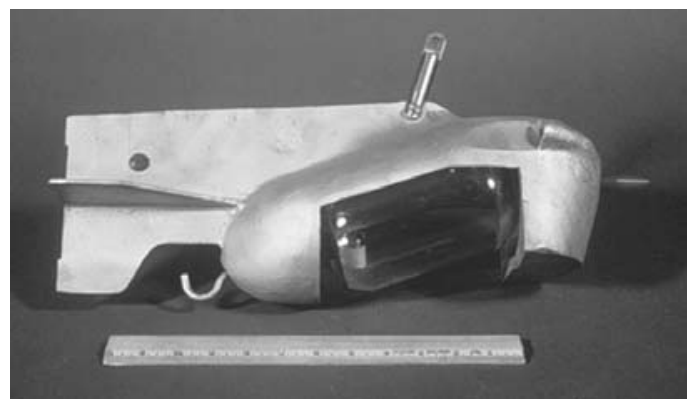

$\mathrm{DH}-76$

Cable suspended samplers

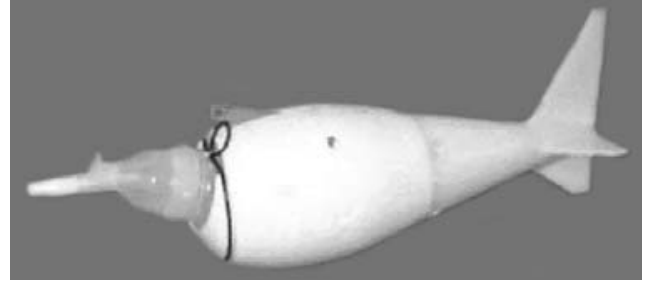

D-95

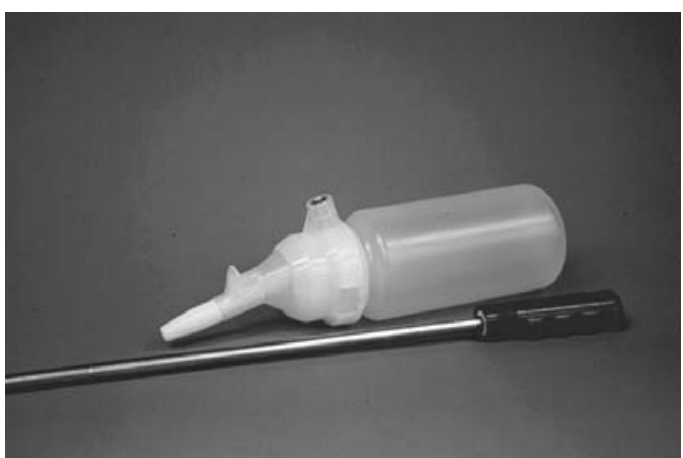

DH-81

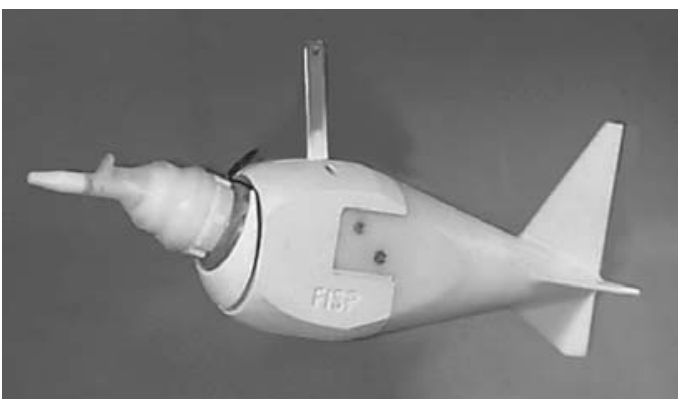

DH-95

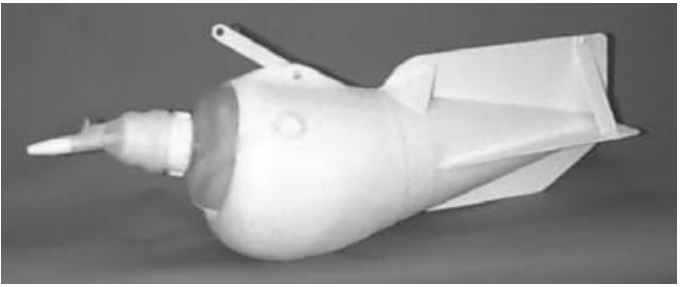

D-77

Figure 3. Selected water-quality and suspended-sediment samplers used in streams and rivers for the Triangle Area Water Supply Monitoring Project, North Carolina. 


\section{Lakes}

At each lake site, measurements of dissolved oxygen, temperature, specific conductance, and $\mathrm{pH}$ were measured at 1-meter (about 3.3-ft) vertical intervals from the surface to the lake bed. A multiparameter data sonde was used to measure and record simultaneous readings of each constituent.

Lake samples were collected by using the dip sample method, a Van Dorn horizontal thief sampler (Wilde and others, 1998b), or a Lab-line ${ }^{\mathrm{TM}}$ sampler (fig. 4). The Lab-line ${ }^{\mathrm{TM}}$ sampler consists of a vertical cylinder that opens only at the top. Two small ports in the top are for water intake and for air exhaust. Caps on each opening can be removed at a specific depth or the ports can be left uncapped so that the chamber fills as the sampler is lowered vertically through the water column.

Prior to 1992, all lake samples were collected at about 1 meter (about $3.3 \mathrm{ft}$ ) below the water surface using the Van Dorn sampler. Near the beginning of phase II, in April 1992, lake-sampling methods used by the USGS were changed to match methods used by the DWQ for lake sampling. That is, nutrient and chlorophyll $a$ samples were collected with the Lab-line ${ }^{\mathrm{TM}}$ sampler leaving the two ports uncapped in order to collect a sample integrated throughout the water column to a depth of twice the secchi depth reading. Other organic and inorganic constituents were collected by using the dip method at about 0.3 meter (about $0.98 \mathrm{ft}$ ) below

Lab-line sampler



bottom. The location of the thermocline was determined from measurements of dissolved-oxygen concentrations taken at 1-meter (about 3.3-ft) intervals throughout the water column.

Prior to October 1989, samples from University Lake and the Eno River at Hillsborough were collected directly from a tap on the municipal water-supply intake line. This resulted in copper contamination because the intake line was made of copper. In October 1989, both sampling locations were moved so that the samples were collected directly from the raw-water supply.

\section{Sample Processing}

Each piece of sampling equipment that had contact with sample water (churn splitters, sample-collection bottles, sampler nozzles, peristaltic pump hose, Lab-line ${ }^{\mathrm{TM}}$ or Van Dorn samplers) was cleaned with a laboratory-grade phosphate-free detergent, rinsed with tap water, and given several final rinses with de-ionized water produced in the USGS North Carolina District office. The parts-per-billion protocol introduced in 1994 required more rigorous cleaning, including an additional soak in a 5-percent hydrochloric acid solution prior to the final de-ionized water rinse, and careful packaging in a plastic bag after cleaning to maintain cleanliness (U.S. Geological Survey, 1997).

Sample processing includes compositing EWI subsamples, filtering the sample through a 0.45 -micron $(\mu)$ membrane filter, filling sample bottles, and preserving the samples. All sample processing for stream and small lake sites was completed onsite and in accordance with USGS protocols and requirements specified by the USGS National Water Quality Laboratory (NWQL) for the particular analyses being requested (table 5). Samples collected from a boat on Falls and Jordan Lakes were processed either onboard the boat onsite or in the field vehicle after completing all lake-sample collections. The decision on where to process these samples depended on lake conditions at the time of sampling.

Van Dorn sampler

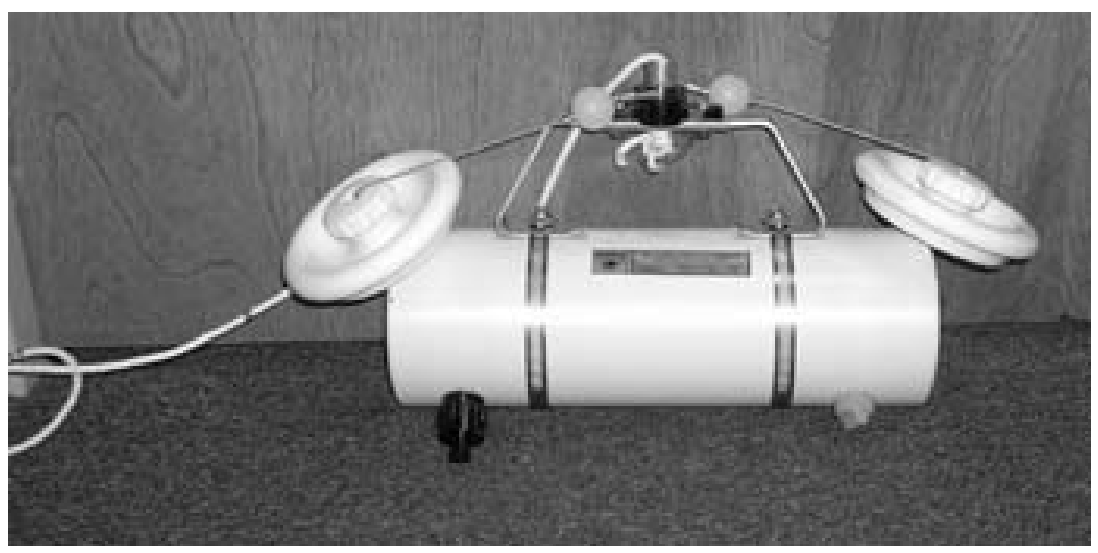

Figure 4. Lake samplers used for the Triangle Area Water Supply Monitoring Project in North Carolina. 
Table 5. Sample schedules, bottle requirements, and preservation of samples analyzed at the U.S. Geological Survey National Water Quality Laboratory.

[NWQL, National Water Quality Laboratory; $\mathrm{mL}$, milliliter; poly., polyethylene; raw, unfiltered sample; chilled, held on ice to a temperature of 4 degrees Celsius $\left({ }^{\circ} \mathrm{C}\right) ; \mathrm{HgCl}$, mercuric chloride tablet added; filtered, poured through a 0.45 -micron pore size membrane filter; $\mathrm{HCl}$, hydrochloric acid; $4.5 \mathrm{~N} \mathrm{H}_{2} \mathrm{SO}_{4}, 4.5 \mathrm{normal}$ sulfuric acid was added to $\mathrm{pH}$ less than $(<) 2 ; \mathrm{HNO}_{3}$, nitric acid added to $\mathrm{pH}<2 ; 6 \mathrm{~N} \mathrm{HCl}, 6$ normal ultra-pure hydrochloric acid was added to $\mathrm{pH}<2 ; \mathrm{KCr}_{2}$, potassium dichromate preservative was added; $\mathrm{L}$, liter; baked, heated in oven to $450{ }^{\circ} \mathrm{C} ; \mu \mathrm{g} / \mathrm{L}$, microgram per liter]

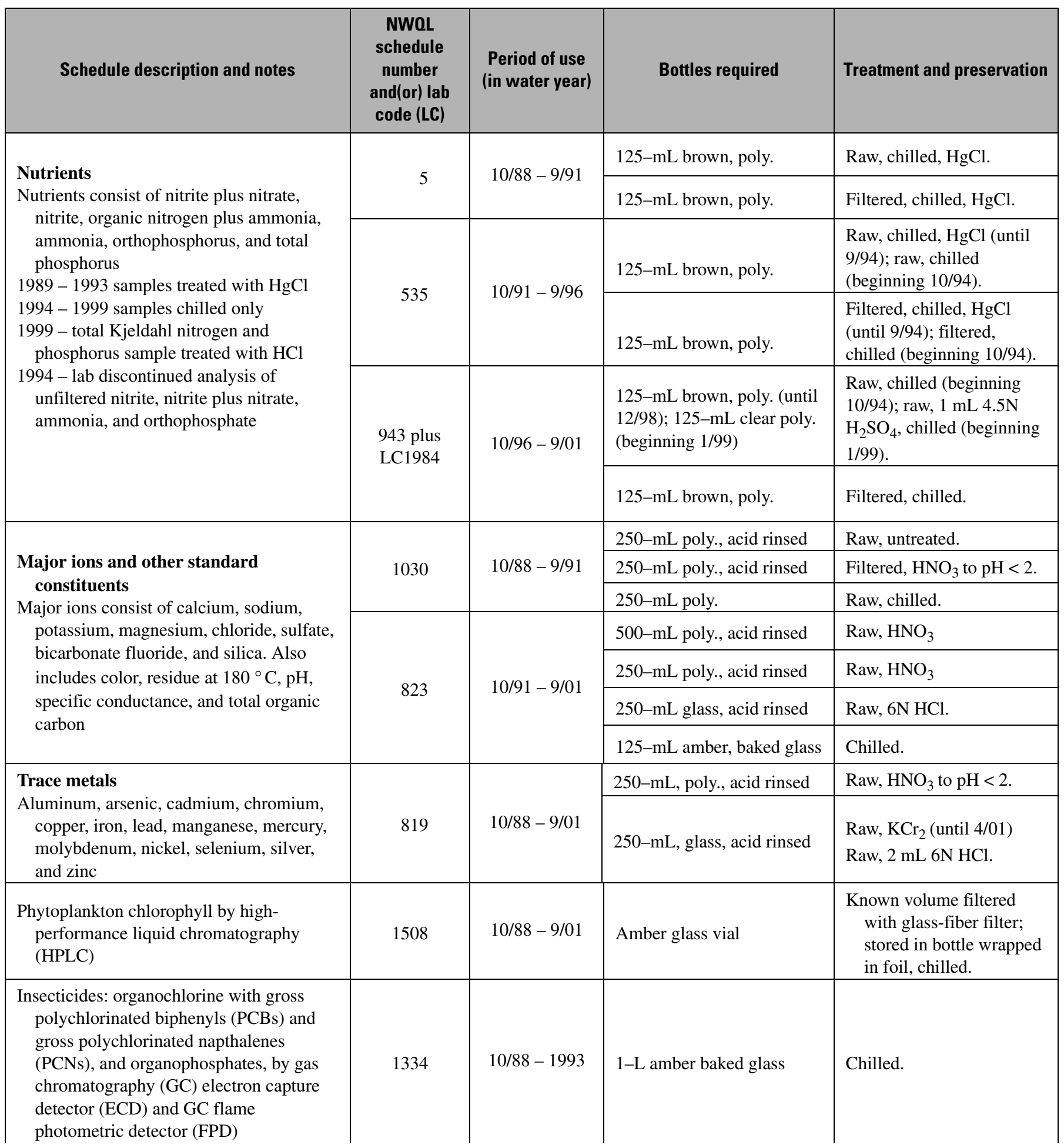


Table 5. Sample schedules, bottle requirements, and preservation of samples analyzed at the U.S. Geological Survey National Water Quality Laboratory.-Continued

[NWQL, National Water Quality Laboratory; $\mathrm{mL}$, milliliter; poly., polyethylene; raw, unfiltered sample; chilled, held on ice to a temperature of 4 degrees Celsius $\left({ }^{\circ} \mathrm{C}\right) ; \mathrm{HgCl}$, mercuric chloride tablet added; filtered, poured through a 0.45 -micron pore size membrane filter; $\mathrm{HCl}$, hydrochloric acid; $4.5 \mathrm{~N} \mathrm{H}_{2} \mathrm{SO}_{4}, 4.5$ normal sulfuric acid was added to $\mathrm{pH}$ less than $(<) 2 ; \mathrm{HNO}_{3}$, nitric acid added to $\mathrm{pH}<2 ; 6 \mathrm{~N} \mathrm{HCl}, 6$ normal ultra-pure hydrochloric acid was added to $\mathrm{pH}<2 ; \mathrm{KCr}_{2}$, potassium dichromate preservative was added; $\mathrm{L}$, liter; baked, heated in oven to $450{ }^{\circ} \mathrm{C} ; \mu \mathrm{g} / \mathrm{L}$, microgram per liter]

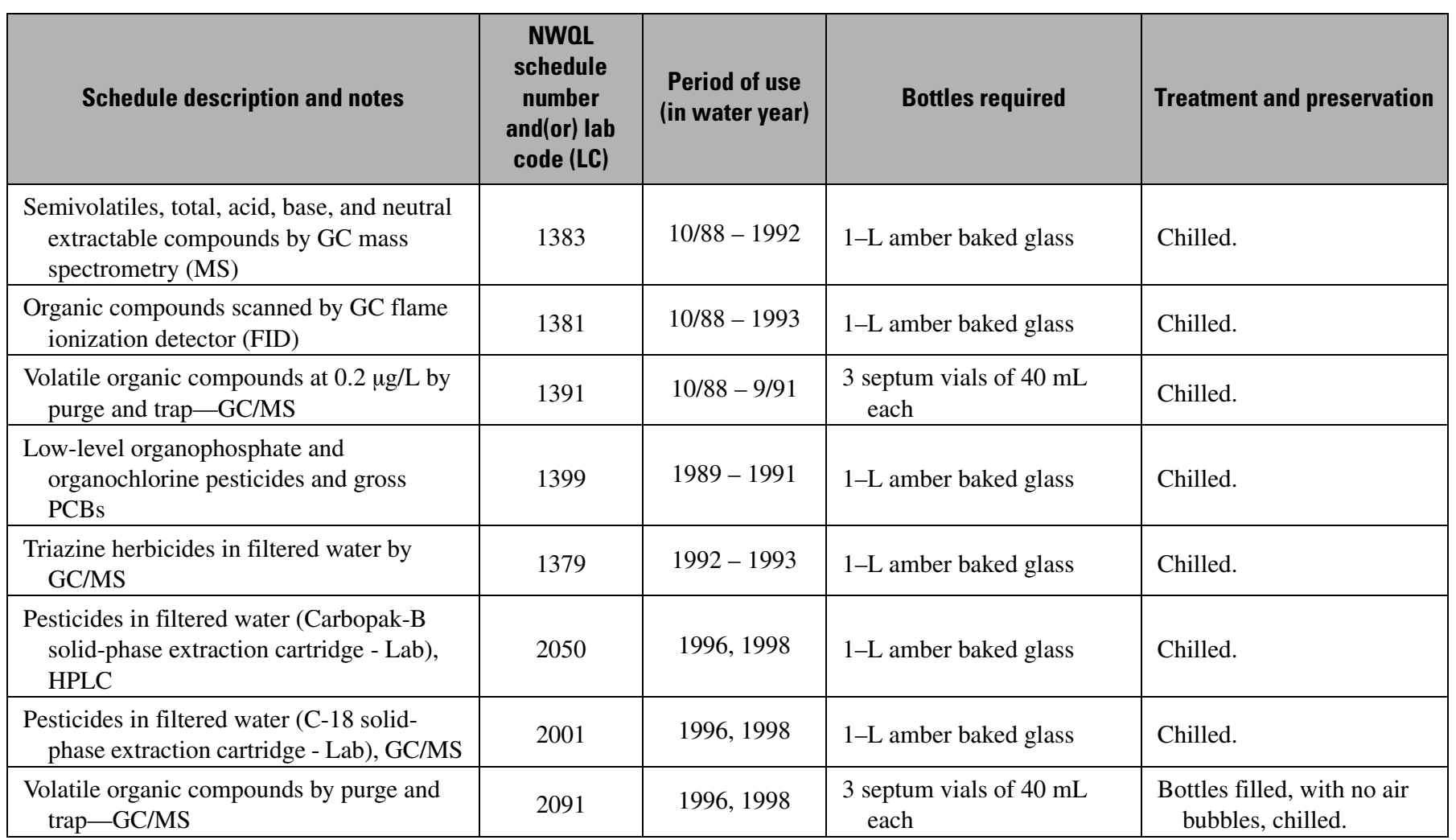

First, sample bottles for constituents that do not require filtration, such as total metals, total nutrients, and major ions, were filled by using the paddle of the churn splitter to mix the composited sample while a subsample was withdrawn into the sample bottle. Next, sample bottles for constituents that require filtration were filled. A peristaltic pump was used to pump the composite sample from the churn splitter through a filter and into the sample bottle. An inert tubing, usually C-Flex ${ }^{\mathrm{TM}}$, was used to pump water through a 142 -millimeter $(\mathrm{mm}) 0.45-\mu$, cellulose-nitrate membrane filter using a peristaltic pump and Geotech ${ }^{\circledR}$ polycarbonate filter holder (before 1994) or through a Gelman ${ }^{\circledR} 0.45-\mu$, polysulfonate, pleated-membrane, disposable, polypropylene capsule filter (after 1994). The filter was pre-rinsed with de-ionized water before use.

Samples for analysis of chlorophyll $a$ and $b$ concentrations were processed by filtering a known volume of sample (typically 100 milliliters [mL]) through a $0.45-\mu$, glass-fiber filter. A pair of forceps was used to remove the filter from the filter screen. The filter then was folded, placed in a plastic petri dish or amber glass vial, wrapped in aluminum foil to exclude light (petri dish only), and placed on ice for shipping. The volume of water that was filtered was recorded on the petri dish or vial.
Samples for the analysis of synthetic organic compounds were sent to the laboratory unfiltered. Filtering of these samples, when required, was done at the laboratory. Samples were collected in brown, baked-glass bottles and placed on ice for shipping.

\section{Streamflow Measurement}

Instantaneous streamflow at the time of sample collection was obtained by applying a site-specific stage-discharge relation to the stage record at stream sites in the network that were equipped with a continuous record gage (table 2). Rantz and others (1983) describe USGS methods for operating and maintaining streamflow-gaging stations by developing a stagestreamflow relation. Streamflow record is developed from periodic instantaneous measurements of stage and streamflow that are used to construct a stage-streamflow relation. The stagestreamflow relation is used to calculate continuous streamflow from 15- to 60-minute-interval stage record.

Streamflow for Morgan Creek near Farrington (site 32, fig. 2) was estimated from streamflow measured by the upstream gage at Chapel Hill (about a 10-percent difference in 
drainage area). Streamflow for the Neuse River at Smithfield (site 20, fig. 2) was estimated from the Neuse River gage at Clayton (about a 5-percent difference in drainage area). Streamflow for the Cape Fear River near Brickhaven (site 41, fig. 2) was estimated by adding daily mean releases from Jordan Lake reported to the USGS by the U.S. Army Corps of Engineers and the mean daily streamflow from the gage on the Deep River at Moncure. Beginning in 1992, instantaneous streamflow was measured at the time of sample collection at Swift Creek at Apex and the Neuse River at Smithfield. To measure streamflow, a Pygmy or Price AA velocity meter was used (Rantz and others, 1983). Most sampling sites without gages were discontinued by 1995 .

A goal of the project is to sample water quality for a range of streamflow conditions at each site with particular attention to sampling during high-flow events when most of the constituent load of concern is transported. Over the long term, the fixedinterval monitoring design of this project (once per month or once per 2 months) was expected to produce the desired range of conditions. However, to ensure that sufficient highstreamflow events are sampled for adequate definition of waterquality conditions during high streamflow, an additional five samples per year specifically were targeted for high-streamflow events.

Streamflow durations were used to assess whether high streamflows were sampled during the study at a frequency comparable to or greater than the long-term frequency of highstreamflow events. A streamflow-duration curve indicates the percentage of time that specific streamflow quantities are equaled or exceeded based on a given period of record. Figure 5 illustrates a comparison of long-term streamflow durations - streamflow durations based on the entire period of record at a gage - with streamflow durations based only on streamflows sampled during the study. Using Little River near Orange Factory (site 5, fig. 2) as an example, a streamflow of 150 cubic feet per second $\left(\mathrm{ft}^{3} / \mathrm{s}\right)$ was equaled or exceeded about 10 percent of the time based on long-term record (fig. 5C). By comparison, a streamflow of about $800 \mathrm{ft}^{3} / \mathrm{s}$ was equaled or exceeded about 10 percent of the time based on streamflow sampled for the study. Therefore, the streamflows that were sampled were somewhat biased toward high-streamflow events.

In general, when the duration curve for sampled streamflows is above the long-term duration curve, as it was for Little River near Orange Factory, sampling was somewhat biased toward high-streamflow events. When the sampled duration curve is below the long-term duration curve, as it was for Morgan Creek near Farrington (site 32, fig. 5O) and Eno River near Durham (site 3, fig. 5B), sampling was somewhat biased toward low-streamflow periods. The goal was to bias sampling slightly toward high-streamflow events because most transport of sediments, nutrients, and other constituents associated with sediment occurs during high-flow events.

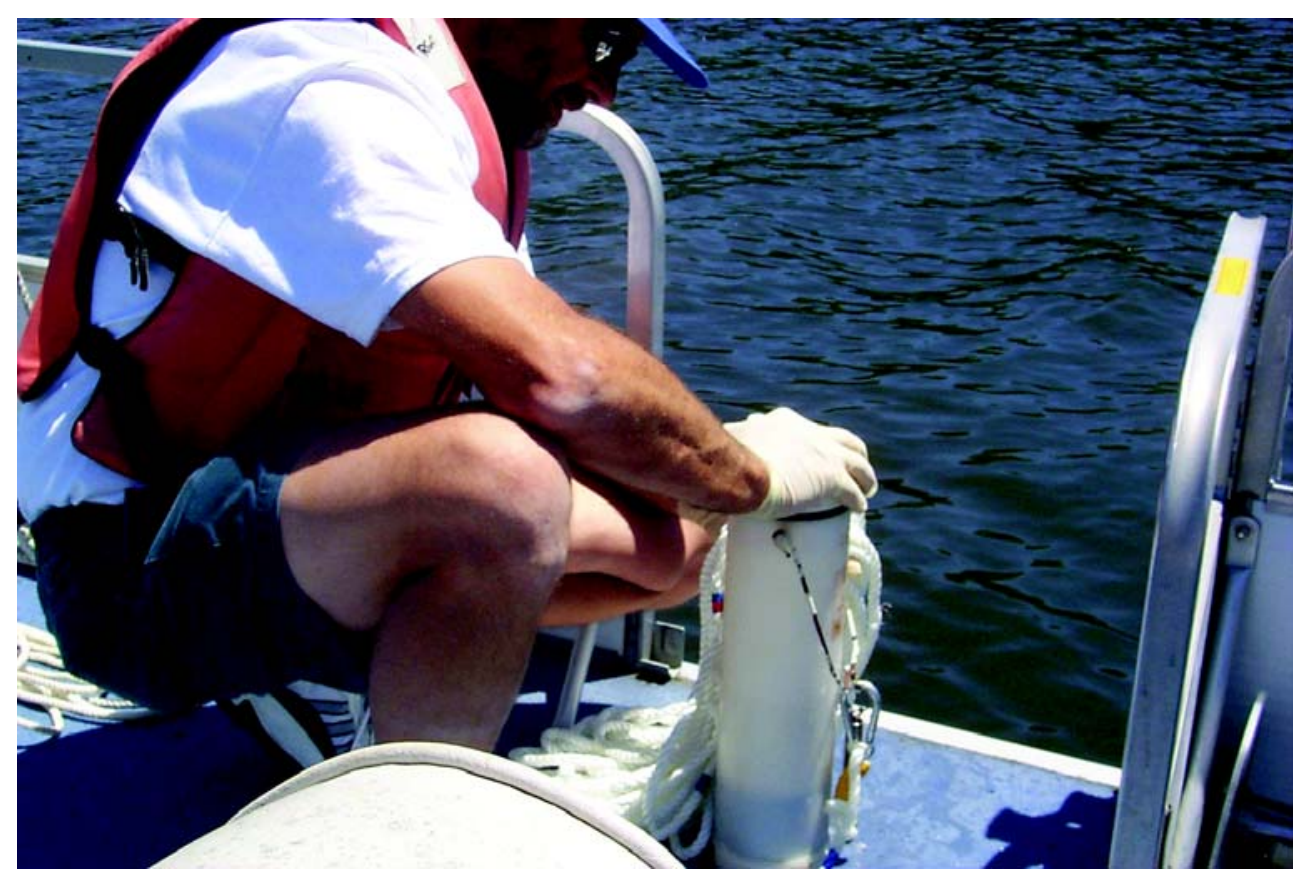

A USGS hydrologic technician collecting a water-quality sample. 


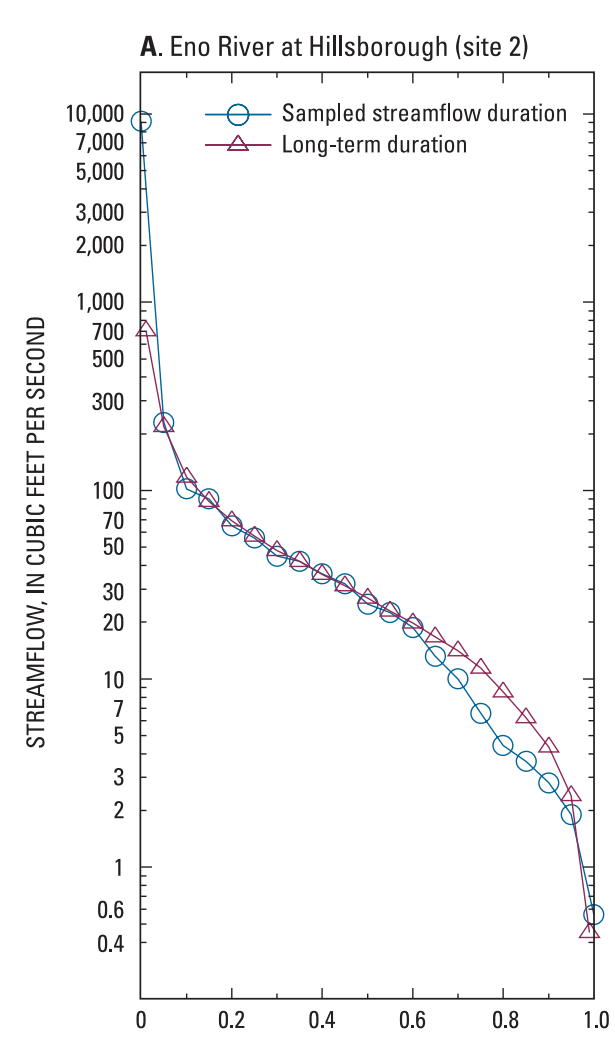

B. Eno River near Durham (site 3) and near Weaver (site 4)

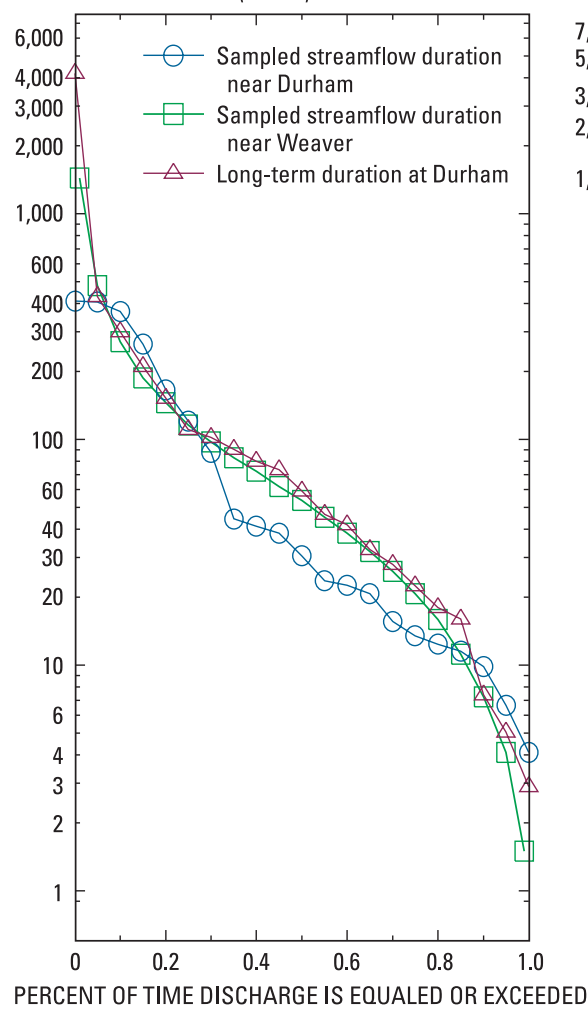

D. Flat River at Bahama (site 8)

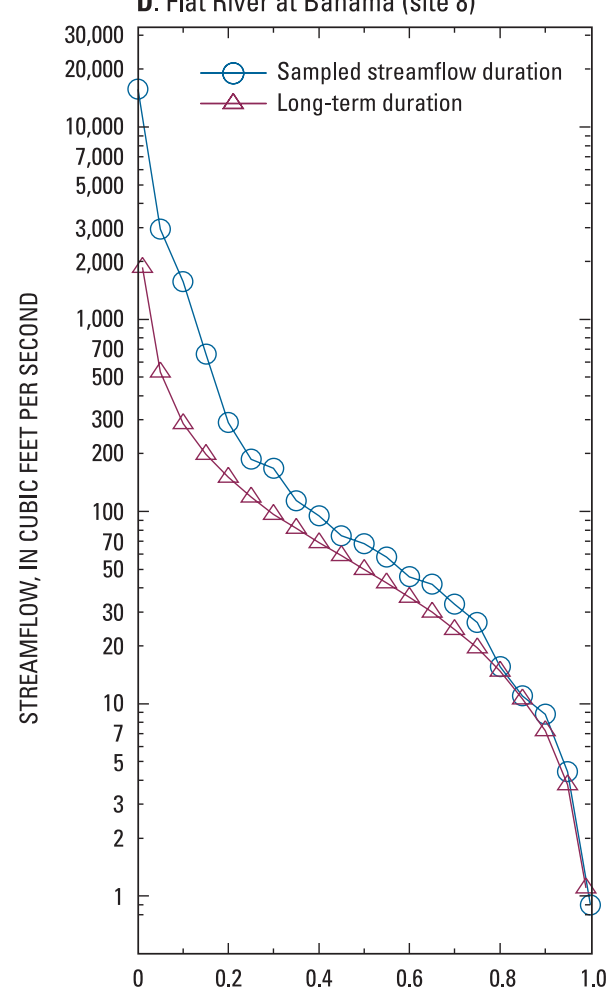

E. Knap of Reeds Creek near Butner (site 11)

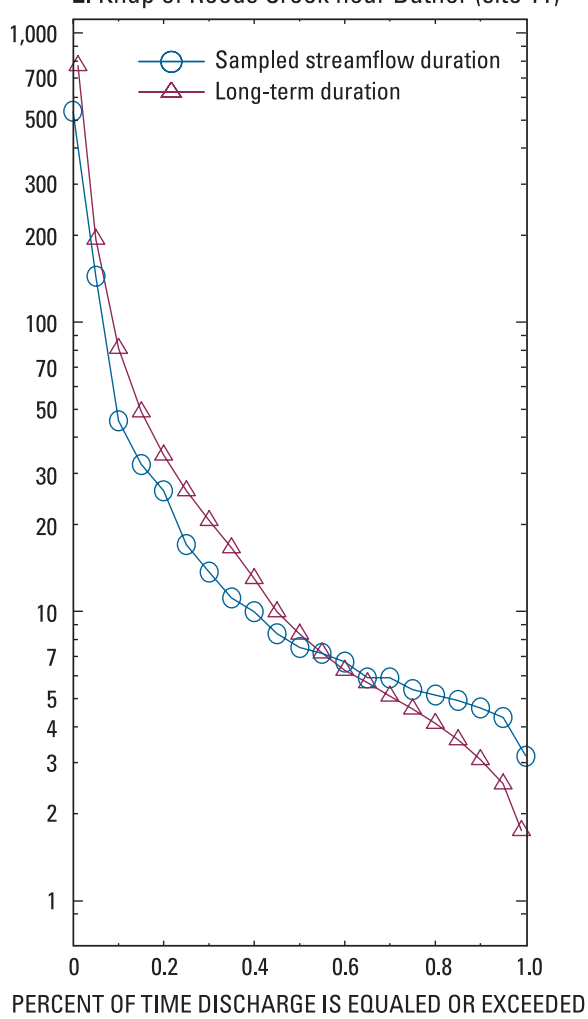

C. Little River near Orange Factory (site 5)

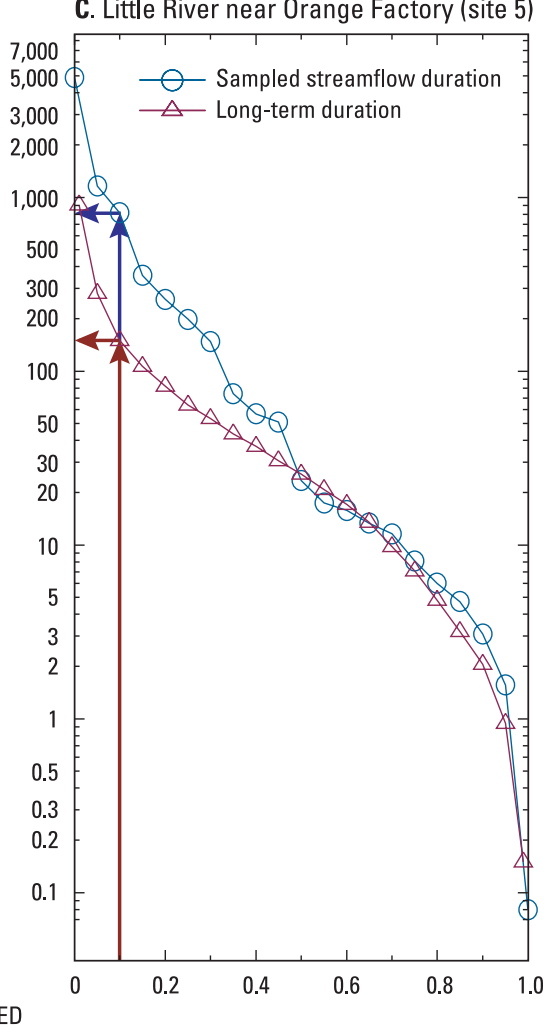

F. Ellerbe Creek near Gorman (site 12)

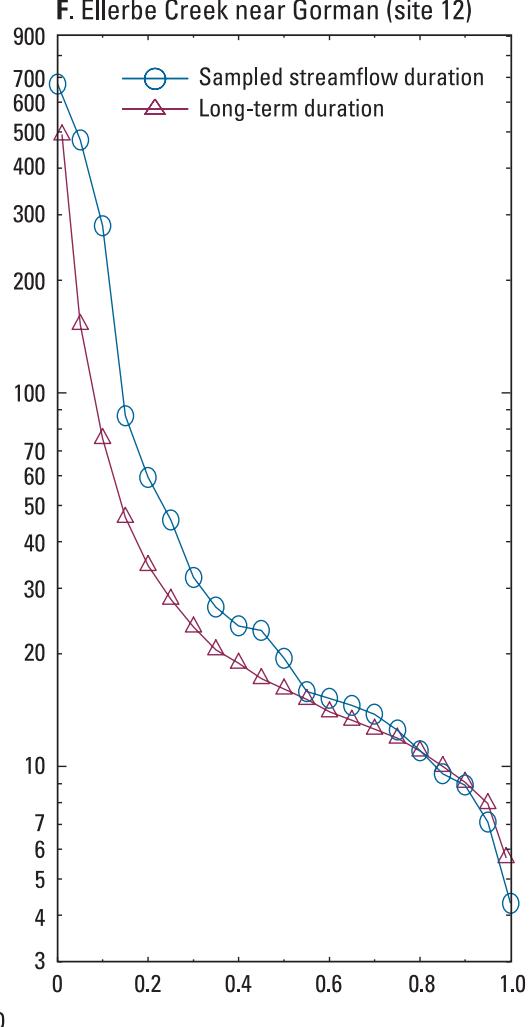

Figure 5. Comparison of streamflow durations from long-term streamflow record with durations for sampled streamflow conditions. 

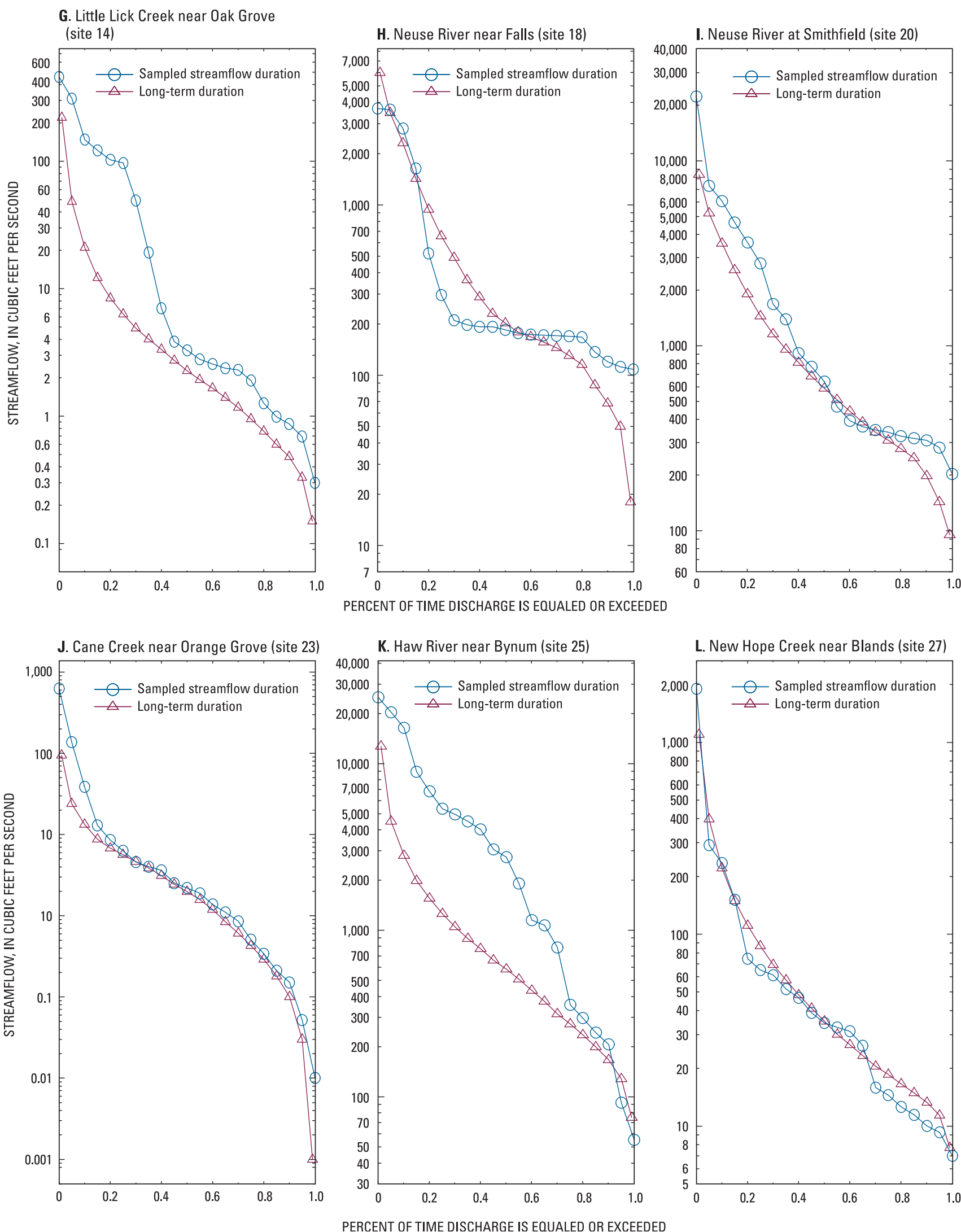

Figure 5. (Continued) Comparison of streamflow durations from long-term streamflow record with durations for sampled streamflow conditions. 

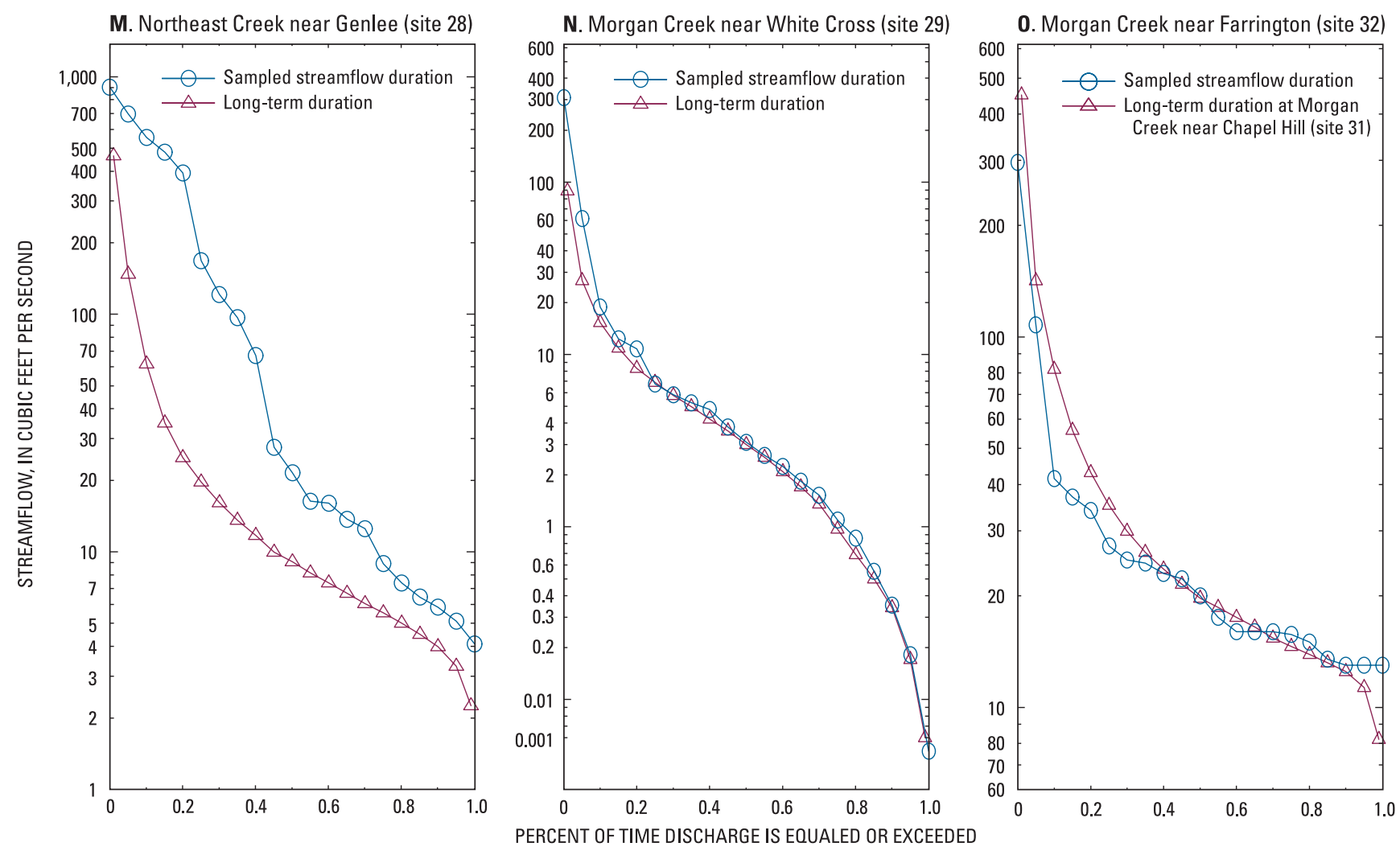

Figure 5. (Continued) Comparison of streamflow durations from long-term streamflow record with durations for sampled streamflow conditions.

\section{Laboratory Analysis}

The DWQ Laboratory Section analyzed samples collected by the DWQ. The constituents generally analyzed in water samples collected by the DWQ at the ambient water-quality monitoring network sites and the frequency of sample collection are listed in table 6. The NWQL in Lakewood, Colorado, analyzed all water-quality samples collected by the USGS (tables 7, 8, p. 45-56) except for suspended-sediment samples. Samples were processed and preserved onsite according to methods used by the NWQL (table 5). Sample bottles were packed on ice and shipped to the laboratory using overnight express-delivery service. Once received at the laboratory, samples were logged into the laboratory computer system and assigned a laboratory identification number.

Suspended-sediment samples were analyzed by the USGS North Carolina District sediment laboratory prior to 1996 and by the USGS Kentucky District sediment laboratory thereafter. Samples sent to Kentucky for analysis were boxed and shipped to the laboratory without preservation. Samples were analyzed by the method described in Guy (1969).

\section{Quality-Assurance and Quality-Control Practices}

Quality assurance and quality control encompass the activities designed to define the quality of the data collected for the project. Quality assurance associated with this project included adherence to standard USGS protocols for sample collection and processing, periodic review of field activities by the senior water-quality technician or water-quality specialist in the USGS North Carolina District, and participation by field staff in the USGS Field Quality-Assurance Program. This program provides field staff with once- or twice-yearly unknown samples for analysis of $\mathrm{pH}$, specific conductance, and alkalinity. In addition, USGS project technical review includes reviews of project activities by District management and senior technical staff at least three times per year and triennial reviews conducted by the USGS Water-Resources Discipline, Office of Water-Quality.

Quality-control activities included the collection of blank and replicate samples for chemical analysis, use of standard 
Table 6. North Carolina Division of Water Quality sampling schedule and analytical methods for sites in the Triangle Area Water Supply Monitoring Project.

$\left[\mathrm{QW}\right.$, water quality; ${ }^{\circ} \mathrm{C}$, degrees Celsius; $\mu \mathrm{S} / \mathrm{cm}$, microsiemens per centimeter at $25{ }^{\circ} \mathrm{C}$; std units, standard units; $\mathrm{mg} / \mathrm{L}$, milligram per liter; $\mathrm{N}$, nitrogen; P, phosphorus; AA, atomic absorption spectrometry; $\mu \mathrm{g} / \mathrm{L}$, microgram per liter]

\begin{tabular}{|c|c|c|c|c|}
\hline Constituent & $\begin{array}{l}\text { Reporting } \\
\text { units }\end{array}$ & $\begin{array}{c}\text { Sampling } \\
\text { frequency } \\
\text { (samples per } \\
\text { year) }\end{array}$ & Analytical method & $\begin{array}{l}\text { Detection } \\
\text { limit }\end{array}$ \\
\hline \multicolumn{5}{|c|}{ Physical properties and general $\mathrm{OW}$} \\
\hline Temperature & ${ }^{\circ} \mathrm{C}$ & $10-12$ & Thermometer/thermistor & 0.5 \\
\hline Specific conductance & $\mu \mathrm{S} / \mathrm{cm}$ & $10-12$ & Electrometric & 1 \\
\hline $\mathrm{pH}$ & std units & $10-12$ & Electrometric & 0.1 \\
\hline Dissolved oxygen & $\mathrm{mg} / \mathrm{L}$ & $10-12$ & Electrometric & 0.1 \\
\hline Hardness & $\mathrm{mg} / \mathrm{L}$ & $3-4$ & titration & 1 \\
\hline Residue on evaporation at $105^{\circ} \mathrm{C}$, suspended & $\mathrm{mg} / \mathrm{L}$ & $3-4$ & Gravimetric & 1 \\
\hline Residue on evaporation at $105^{\circ} \mathrm{C}$, total & $\mathrm{mg} / \mathrm{L}$ & $3-4$ & Gravimetric & 1 \\
\hline Chlorophyll $a$ & $\mathrm{mg} / \mathrm{L}$ & $3-4$ & Fluorometric & 1 \\
\hline Chlorophyll $b$ & $\mathrm{mg} / \mathrm{L}$ & $3-4$ & Fluorometric & 1 \\
\hline \multicolumn{5}{|c|}{ Nutrients } \\
\hline Total nitrogen as $\mathrm{N}$ & $\mathrm{mg} / \mathrm{L}$ & $10-12$ & Calculated & \\
\hline Total ammonia plus organic nitrogen as $\mathrm{N}$ & $\mathrm{mg} / \mathrm{L}$ & $10-12$ & Automated phenate, colorimetry & 0.1 \\
\hline Total ammonia as $\mathrm{N}$ & $\mathrm{mg} / \mathrm{L}$ & $10-12$ & Automated phenate, colorimetry & 0.01 \\
\hline Total nitrite plus nitrate as $\mathrm{N}$ & $\mathrm{mg} / \mathrm{L}$ & $10-12$ & $\begin{array}{l}\text { Cadmium reduction, automated, } \\
\text { colorimetry }\end{array}$ & 0.01 \\
\hline Total phosphorus as $\mathrm{P}$ & $\mathrm{mg} / \mathrm{L}$ & $10-12$ & $\begin{array}{l}\text { Persulfate digestion, automated, } \\
\text { ascorbic acid reduction, colorimetry }\end{array}$ & 0.01 \\
\hline Total orthophosphorus as $\mathrm{P}$ & $\mathrm{mg} / \mathrm{L}$ & $10-12$ & $\begin{array}{l}\text { Ascorbic acid reduction, automated, } \\
\text { colorimetry }\end{array}$ & 0.01 \\
\hline \multicolumn{5}{|c|}{ Trace elements } \\
\hline Arsenic & $\mathrm{mg} / \mathrm{L}$ & $3-4$ & Digestion, AA, graphite furnace & 10 \\
\hline Cadmium & $\mu \mathrm{g} / \mathrm{L}$ & $3-4$ & Digestion, AA, graphite furnace & 2 \\
\hline Chromium & $\mu \mathrm{g} / \mathrm{L}$ & $3-4$ & Digestion, AA, direct aspiration & 25 \\
\hline Copper & $\mu \mathrm{g} / \mathrm{L}$ & $3-4$ & Digestion, AA, direct aspiration & 10 \\
\hline Lead & $\mu \mathrm{g} / \mathrm{L}$ & $3-4$ & Digestion, AA, graphite furnace & 10 \\
\hline Mercury & $\mu \mathrm{g} / \mathrm{L}$ & $3-4$ & Digestion, AA, cold vapor & 0.2 \\
\hline Nickel & $\mu \mathrm{g} / \mathrm{L}$ & $3-4$ & Digestion, AA, graphite furnace & 10 \\
\hline Zinc & $\mu \mathrm{g} / \mathrm{L}$ & $3-4$ & Digestion, AA, direct aspiration & 10 \\
\hline
\end{tabular}


protocols for cleaning and storing equipment and supplies, and the purchase and use of preservatives and reagents that are quality assured by the USGS Field Services Unit in Ocala, Florida.

\section{Supplies}

The supplies needed for processing samples generally were purchased from USGS sources. Prior to 1993, most supplies were purchased from the NWQL. The USGS Field Services Unit, in Ocala, Florida, assumed most of the supply service responsibilities from the NWQL beginning in 1993. In both cases, supplies were purchased in bulk, and each lot was quality checked before distribution to USGS offices. Such supplies included sample preservatives, alkalinity reagents, inorganic blank reagent water, organic blank water (from the NWQL only), capsule filters, and sample bottles. Each lot of chemical reagents, bottles, and filters was tested for contamination and performance quality prior to distribution. Bottles were acid rinsed or baked, as required.

De-ionized water produced in the USGS North Carolina District laboratory was used for rinsing equipment and supplies. To produce de-ionized water, a purifying system was installed in which tap water was passed through a $1-\mu$ pre-filter, two deionizing columns placed in series, and a $0.2-\mu$ post filter. The specific conductivity of the water after passage through the first de-ionizing column was monitored continually with an indicator light to determine when resistance was less than 17 megaohms per centimeter (greater than 0.06 microsiemens per centimeter $(\mu \mathrm{S} / \mathrm{cm})$ at 25 degrees Celsius). The first deionizing column in the series was replaced every 6 months or when the indicator light indicated that specific conductance had exceeded the criterion. The second de-ionizing column in the series replaced the first de-ionizing column, and a new deionizing column was added to the second position. To produce field blanks for inorganic constituents, de-ionized water, certified as free from inorganic contaminants, was purchased from the NWQL or the Ocala Field Services Unit.

\section{Record Management and Archive}

Water-quality records were managed, stored, and archived according to the USGS North Carolina District qualityassurance guidelines for water-quality data (North Carolina District Quality-Assurance Plan for Water Quality, written commun., 2000). Streamflow records were managed, stored, and archived according to the USGS North Carolina District quality-assurance guidelines for surface-water data (North Carolina District Quality-Assurance Plan for Surface Water, written commun., 1995). All water-quality and streamflow records are stored in the USGS National Water Information System (NWIS) and are available to the public at http:// waterdata.usgs.gov/nwis/.

\section{Field Notes}

Field notes consist of written observations of field conditions, field instrument-calibration notes, water-quality field measurements, documentation of sample preservation and processing steps, and record of samples collected for shipment to the laboratory. Field notes are filed in folders according to station number and water year and stored at the USGS North Carolina District office. Record of sample-collection date, time, and field conditions and record of field measurements are entered by field staff into the NWIS database.

\section{Water-Quality Analytical Results}

Water-quality analytical results are transferred electronically to the USGS North Carolina District NWIS database from the NWQL. Paper copies of analytical results are printed and filed with the field notes in folders according to station number and water year. Suspended-sediment concentration results are reported from the laboratory in a written report. Results are entered in the NWIS database, and the written report is filed with other sample records for the same sample event.

Analytical results are reviewed for consistency by the NWQL quality-assurance unit and, upon receipt, by the USGS North Carolina District water-quality specialist and project chief. If results are judged to be questionable, the laboratory is asked to verify the results and, if necessary, rerun the sample analysis. When this occurs, the new result is compared with the original result, and the result judged most reasonably correct is entered into the database.

Gas chromatography with flame ionization detector (GC/FID) scans for synthetic organic analysis were qualitative, and only a paper copy of the results of the scan was provided by the laboratory. The qualitative results-copies of gas chromatography traces and results of a library search for probable identification of peaks on the chromatograph-were filed and archived with the other project paper records.

\section{Streamflow Records}

Streamflow-gaging stations were operated and maintained according to established USGS protocols (Rantz and others, 1983) and North Carolina District guidelines (North Carolina District Quality-Assurance Plan for Surface Water, written commun., 1995). Records of daily mean streamflow are stored permanently in the NWIS database. Records of unit values (15to 60-minute intervals) of stage and streamflow are stored permanently in the NWIS database with the exception of a few years when electronically stored data were lost because of a computer error (table 9). Paper copies of unit-value discharge data for these periods are available in the USGS North Carolina District office. 
Table 9. Status of electronic storage of unit-value data for water years 1989-2001 in the U.S. Geological Survey National Water Information System database for the Triangle Area Water Supply Monitoring Project in North Carolina.

[USGS site number, the downstream order number assigned by the U.S. Geological Survey to each streamflow-gaging site; U, unit-value data stored electronically; X, unit-value data available only on paper copies; SR, secondary road; shaded area indicates years with no streamflow gage]

\begin{tabular}{|c|c|c|c|c|c|c|c|c|c|c|c|c|c|c|}
\hline \multirow{2}{*}{$\begin{array}{l}\text { USGS site } \\
\text { number }\end{array}$} & \multirow{2}{*}{ USGS site name } & \multicolumn{13}{|c|}{ Water year } \\
\hline & & 89 & 90 & 91 & 92 & 93 & 94 & 95 & 96 & 97 & 98 & 99 & $\mathbf{0 0}$ & 01 \\
\hline 02085000 & Eno River at Hillsborough & $\mathrm{U}$ & $\mathrm{U}$ & $\mathrm{U}$ & $\mathrm{U}$ & $\mathrm{X}$ & $\mathrm{U}$ & $\mathrm{U}$ & $\mathrm{U}$ & $\mathrm{U}$ & $\mathrm{U}$ & $\mathrm{U}$ & $\mathrm{U}$ & $\mathrm{U}$ \\
\hline 02085070 & Eno River near Durham & $\mathrm{U}$ & $\mathrm{U}$ & $\mathrm{U}$ & $\mathrm{X}$ & $\mathrm{X}$ & $\mathrm{U}$ & $\mathrm{U}$ & $\mathrm{U}$ & $\mathrm{U}$ & $\mathrm{U}$ & $\mathrm{U}$ & $\mathrm{U}$ & $\mathrm{U}$ \\
\hline 0208521324 & $\begin{array}{l}\text { Little River at SR } 1461 \text { near Orange } \\
\text { Factory }\end{array}$ & $\mathrm{U}$ & $\mathrm{U}$ & $\mathrm{U}$ & $\mathrm{U}$ & $\mathrm{X}$ & $\mathrm{U}$ & $\mathrm{U}$ & $\mathrm{U}$ & $\mathrm{U}$ & $\mathrm{U}$ & $\mathrm{U}$ & $\mathrm{U}$ & $\mathrm{U}$ \\
\hline 02085500 & Flat River at Bahama & $\mathrm{U}$ & $\mathrm{U}$ & $\mathrm{U}$ & $\mathrm{X}$ & $\mathrm{X}$ & $\mathrm{U}$ & $\mathrm{U}$ & $\mathrm{U}$ & $\mathrm{U}$ & $\mathrm{U}$ & $\mathrm{U}$ & $\mathrm{U}$ & $\mathrm{U}$ \\
\hline 02086624 & Knap of Reeds Creek near Butner & $\mathrm{U}$ & $\mathrm{U}$ & $\mathrm{U}$ & $\mathrm{U}$ & $\mathrm{X}$ & $\mathrm{U}$ & $\mathrm{X}$ & & & & & & \\
\hline 0208700780 & $\begin{array}{l}\text { Little Lick Creek above SR } 1814 \\
\text { near Oak Grove }\end{array}$ & $\mathrm{U}$ & $\mathrm{U}$ & $\mathrm{U}$ & $\mathrm{U}$ & $\mathrm{X}$ & $\mathrm{U}$ & $\mathrm{U}$ & & & & & & \\
\hline 02086849 & Ellerbe Creek near Gorman & $\mathrm{U}$ & $\mathrm{X}$ & $\mathrm{X}$ & $\mathrm{U}$ & $\mathrm{X}$ & $\mathrm{U}$ & $\mathrm{U}$ & & & & & & \\
\hline 02087183 & Neuse River near Falls & $\mathrm{U}$ & $\mathrm{U}$ & $\mathrm{U}$ & $\mathrm{X}$ & $\mathrm{X}$ & $\mathrm{U}$ & $\mathrm{U}$ & $\mathrm{U}$ & $\mathrm{U}$ & $\mathrm{U}$ & $\mathrm{U}$ & $\mathrm{U}$ & $\mathrm{U}$ \\
\hline 02087570 & Neuse River at Smithfield & $\mathrm{U}$ & $\mathrm{U}$ & & & & & & & & & & & \\
\hline 02096846 & Cane Creek near Orange Grove & $\mathrm{U}$ & $\mathrm{U}$ & $\mathrm{U}$ & $\mathrm{X}$ & $\mathrm{U}$ & $\mathrm{U}$ & $\mathrm{U}$ & $\mathrm{U}$ & $\mathrm{U}$ & $\mathrm{U}$ & $\mathrm{U}$ & $\mathrm{U}$ & $\mathrm{U}$ \\
\hline 02096960 & Haw River near Bynum & $\mathrm{U}$ & $\mathrm{U}$ & $\mathrm{U}$ & $\mathrm{X}$ & $\mathrm{U}$ & $\mathrm{U}$ & $\mathrm{U}$ & $\mathrm{X}$ & $\mathrm{U}$ & $\mathrm{U}$ & $\mathrm{U}$ & $\mathrm{U}$ & $\mathrm{U}$ \\
\hline 02097314 & New Hope Creek near Blands & $\mathrm{U}$ & $\mathrm{U}$ & $\mathrm{U}$ & $\mathrm{X}$ & $\mathrm{U}$ & $\mathrm{U}$ & $\mathrm{U}$ & $\mathrm{U}$ & $\mathrm{U}$ & $\mathrm{U}$ & $\mathrm{U}$ & $\mathrm{U}$ & $\mathrm{U}$ \\
\hline 0209741955 & $\begin{array}{l}\text { Northeast Creek at SR } 1100 \text { near } \\
\text { Genlee }\end{array}$ & $\mathrm{U}$ & $\mathrm{U}$ & $\mathrm{U}$ & $\mathrm{X}$ & $\mathrm{X}$ & $\mathrm{U}$ & $\mathrm{U}$ & $\mathrm{U}$ & $\mathrm{U}$ & $\mathrm{U}$ & $\mathrm{U}$ & $\mathrm{U}$ & $\mathrm{U}$ \\
\hline 02097464 & Morgan Creek near White Cross & $\mathrm{U}$ & $\mathrm{U}$ & $\mathrm{U}$ & $\mathrm{X}$ & $\mathrm{U}$ & $\mathrm{U}$ & $\mathrm{U}$ & $\mathrm{U}$ & $\mathrm{U}$ & $\mathrm{U}$ & $\mathrm{U}$ & $\mathrm{U}$ & $\mathrm{U}$ \\
\hline 02097517 & Morgan Creek near Chapel Hill & $\mathrm{U}$ & $\mathrm{U}$ & $\mathrm{U}$ & $\mathrm{X}$ & $\mathrm{U}$ & $\mathrm{U}$ & $\mathrm{U}$ & $\mathrm{U}$ & $\mathrm{U}$ & $\mathrm{U}$ & $\mathrm{U}$ & $\mathrm{U}$ & $\mathrm{U}$ \\
\hline 0209782520 & White Oak Creek at Green Level & & & & & & & & & & & $\mathrm{X}$ & $\mathrm{U}$ & $\mathrm{U}$ \\
\hline 02098198 & $\begin{array}{l}\text { Haw River below B. Everett Jordan } \\
\text { dam near Moncure }\end{array}$ & $\mathrm{U}$ & $\mathrm{U}$ & $\mathrm{U}$ & $\mathrm{X}$ & & & & & & & & & \\
\hline
\end{tabular}

\section{Field Quality Control}

The purpose of field quality-control sampling is to determine the effects of sample-collection and handling procedures and laboratory processes on the concentration of constituents in the stream or lake sample (hereafter referred to as the environmental sample) and to assess the replicability of results by field and laboratory processes. Field quality-control samples collected for this study consisted of blanks and replicates.

\section{Blank Samples}

Most blank samples were equipment blanks (table 10). In addition, trip blanks (also identified as boat blanks, vehicle blanks, and truck blanks), and the USGS North Carolina District office de-ionized
Table 10. Numbers and types of blank samples collected for the Triangle Area Water Supply Monitoring Project in North Carolina, 1988-2001.

[USGS, U.S. Geological Survey]

\begin{tabular}{|c|c|c|c|c|c|}
\hline \multirow{2}{*}{ Blank sample type } & \multirow{2}{*}{$\begin{array}{c}\text { USGS } \\
\text { identifi- } \\
\text { cation } \\
\text { number }\end{array}$} & \multicolumn{4}{|c|}{ Number of samples } \\
\hline & & Nutrients & Metals & $\begin{array}{l}\text { Major } \\
\text { cations }\end{array}$ & $\begin{array}{l}\text { Major } \\
\text { anions }\end{array}$ \\
\hline \multicolumn{6}{|c|}{ Equipment blanks } \\
\hline Stream & 370010100 & 50 & 31 & 37 & 6 \\
\hline Lake & 370010101 & 19 & 14 & 14 & 0 \\
\hline \multicolumn{6}{|c|}{ Trip blanks } \\
\hline Vehicle & 370010102 & 17 & 16 & 16 & 0 \\
\hline Truck & 10100009 & 1 & 1 & 1 & 0 \\
\hline Boat & 10100007 & 4 & 4 & 4 & 0 \\
\hline Trip (unspecified) & 10100004 & 1 & 1 & 1 & 0 \\
\hline $\begin{array}{l}\text { De-ionized water } \\
\text { supply }\end{array}$ & 99000001 & 7 & 5 & 5 & 0 \\
\hline Total blanks & & 99 & 72 & 78 & 6 \\
\hline
\end{tabular}


water blanks were prepared. Equipment blanks are used to test for sample contamination from collection, processing, and preservation procedures. Vehicle blanks are used to test for sample contamination from transport of sample bottles in a particular vehicle or during an entire sampling trip. The USGS District office de-ionized water blank was used to test the quality of the de-ionized water produced in the USGS North Carolina District laboratory and used for cleaning and rinsing equipment and supplies.

\section{De-ionized Water Blanks}

Samples of de-ionized water produced in the USGS North Carolina District office were collected and analyzed to document the quality of de-ionized water that was used to clean and rinse equipment and supplies. Concentrations of major ions, trace elements, and metals in the de-ionized water typically were less than detection levels (table 11). Samples were analyzed using methods with low detection levels-less than detection levels for environmental samples.

\section{Equipment and Trip Blanks}

For equipment blanks, de-ionized water certified by the producer as free of inorganic contamination (inorganic free) was poured through all of the clean sampling equipment, bottled, and preserved using the same procedures as those used to process and preserve stream and lake samples (hereafter, referred to as environmental samples to differentiate them from blank samples). Trip blanks were produced by pouring inorganic-free de-ionized water into a sample bottle and transporting the bottle to and from the site in a truck, boat, or both during a sampling trip.

Results of blank sample analysis were examined for inorganic constituents, total organic carbon, and color, for which environmental sample results also were analyzed (table 12). The method used for analysis of metals and trace elements in blank samples changed in 1994, resulting in analyses of total constituents and dissolved constituents. Prior to August 1994, blank samples were analyzed by using the same methods as those used for metals and trace elements in environmental samples. After August 1994, a new method with much lower detection levels for metals and trace elements was used specifically for blank samples. Results were reported for dissolved metals and trace elements because de-ionized water contains no particulates. Results of these analyses are shown separately in table 12 . With the new method, seven trace elements were analyzed in blank samples that were not analyzed in the associated environmental samples. These trace elements were antimony, barium, beryllium, boron, strontium, titanium, and uranium. Results of these analyses are listed at the end of table 12 .

Results of blank sample analysis are an indication of the minimum environmental concentrations that can be measured and attributed to the environment rather than to contamination that may occur during some part of the sample collection, processing, preservation, shipping, and analysis process. The median and $90^{\text {th }}$ percentile concentrations for equipment and vehicle blank samples for each constituent were calculated (table 12). The 95-percent confidence interval around the median and the upper bound of the 95-percent confidence interval of the $90^{\text {th }}$ percentile were calculated by using nonparametric estimators of confidence limits for percentiles (Gilbert, 1987, p. 141). In addition, the minimum, $10^{\text {th }}$ percentile, median, and $90^{\text {th }}$ percentile concentrations were calculated for the pooled environmental samples (table 12).

The minimum and $10^{\text {th }}$ percentile concentrations in the environmental samples were compared to the upper bound of the 95-percent confidence interval of the $90^{\text {th }}$ percentile concentration for blank samples. The latter value is an indication of the maximum amount of contamination that may have been introduced to the environmental sample during collection and processing. If this value is less than the minimum environmental concentration, then contamination is not a significant factor affecting the measured environmental sample concentration.

For calcium, magnesium, sodium, and silica, the upper bound of the 95-percent confidence interval of the $90^{\text {th }}$ percentile of the blank samples was at least an order of magnitude less than the $10^{\text {th }}$ percentile concentration of the environmental samples. For potassium, chloride, and sulfate, the upper bound of the 95-percent confidence interval of the median of the blank samples was at or near the detection level and was at least an order of magnitude less than the 10th percentile concentration of the environmental samples. The fluoride results typically were below detection in blank and environmental samples. Sample contamination was not a factor for this group of constituents. 
Table 11. Results of analyses of de-ionized water produced in the U.S. Geological Survey North Carolina District office.

[-, no data; E, concentration was estimated below the detection level; $\mu \mathrm{S} / \mathrm{cm}$, microsiemens per centimeter at 25 degrees Celsius; mg/L, milligram per liter; $<$, less than; bold values are above detection levels; $\mu \mathrm{g} / \mathrm{L}$, microgram per liter]

\begin{tabular}{|c|c|c|c|c|c|c|c|c|}
\hline \multirow[b]{2}{*}{$\begin{array}{l}\text { Parameter } \\
\text { code }\end{array}$} & \multirow[b]{2}{*}{ Constituent } & \multicolumn{7}{|c|}{ Date } \\
\hline & & 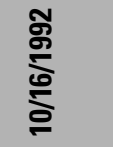 & 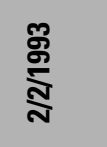 & $\frac{\underset{\delta}{\sigma}}{\underbrace{\circ}_{0}}$ & 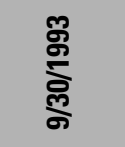 & $\frac{\text { 용 }}{\frac{2}{2}}$ & 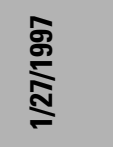 & 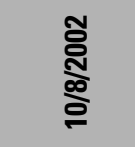 \\
\hline 00403 & $\mathrm{pH}$, laboratory, standard units & - & - & 7 & 8.8 & - & - & 7.4 \\
\hline 90095 & Lab specific conductance, $\mu \mathrm{S} / \mathrm{cm}$ & - & - & 2 & 1 & - & - & E3 \\
\hline 00095 & Field specific conductance, $\mu \mathrm{S} / \mathrm{cm}$ & - & - & - & - & - & 1 & - \\
\hline 00915 & Dissolved calcium (mg/L as $\mathrm{Ca})$ & - & - & $<.02$ & 0.1 & 0.003 & 0.01 & $<.01$ \\
\hline 00925 & Dissolved magnesium (mg/L as $\mathrm{Mg}$ ) & - & - & $<.01$ & $<.01$ & $<.001$ & $<.001$ & $<.008$ \\
\hline 00930 & Dissolved sodium (mg/L as $\mathrm{Na}$ ) & - & - & $<.20$ & $<.20$ & $<.03$ & .05 & $<.09$ \\
\hline 00955 & Dissolved silica (mg/L as $\mathrm{SiO}_{2}$ ) & - & - & $<.01$ & $<.01$ & $<.02$ & .1 & $<.13$ \\
\hline 00608 & Dissolved ammonia (mg/L as $\mathrm{N})$ & - & 0.01 & .003 & .003 & $<.002$ & $<.002$ & $<.015$ \\
\hline 00623 & $\begin{array}{l}\text { Dissolved ammonia plus organic nitrogen } \\
(\mathrm{mg} / \mathrm{L} \text { as } \mathrm{N})\end{array}$ & - & $<.20$ & - & - & - & - & - \\
\hline 00625 & $\begin{array}{l}\text { Total ammonia plus organic nitrogen } \\
(\mathrm{mg} / \mathrm{L} \text { as } \mathrm{N})\end{array}$ & $<0.20$ & $<.20$ & - & - & - & - & - \\
\hline 00610 & Total ammonia (mg/L as $\mathrm{N})$ & $<.010$ & - & - & - & - & - & - \\
\hline 00631 & Dissolved nitrite plus nitrate ( $\mathrm{mg} / \mathrm{L}$ as $\mathrm{N})$ & - & $<.050$ & $<.005$ & $<.005$ & $<.005$ & $<.005$ & $<.022$ \\
\hline 00630 & Total nitrite plus nitrate ( $\mathrm{mg} / \mathrm{L}$ as $\mathrm{N})$ & $<.050$ & - & - & - & - & - & - \\
\hline 00613 & Dissolved nitrite, $\mathrm{mg} / \mathrm{L}$ as $\mathrm{N}$ & - & .01 & $<.001$ & .001 & .001 & $<.001$ & $<.0023$ \\
\hline 00615 & Total nitrite, $\mathrm{mg} / \mathrm{L}$ as $\mathrm{N}$ & $<.010$ & - & - & - & - & - & - \\
\hline 00666 & Dissolved phosphorus (mg/L as P) & - & $<.010$ & - & - & - & - & - \\
\hline 00671 & Dissolved orthophosphate (mg/L as $\mathrm{P}$ ) & - & $<.010$ & $<.001$ & $<.001$ & $<.001$ & .002 & $<.0070$ \\
\hline 70507 & Total orthophosphate, $(\mathrm{mg} / \mathrm{L}$ as $\mathrm{P})$ & $<.010$ & - & - & - & - & - & - \\
\hline 00665 & Total phosphorus total (mg/L as $\mathrm{P}$ ) & $<.010$ & $<.010$ & - & - & - & - & - \\
\hline 01106 & Dissolved aluminum ( $\mu \mathrm{g} / \mathrm{L}$ as $\mathrm{Al})$ & - & - & - & - & 3.27 & $<.30$ & $<1.6$ \\
\hline 01095 & Dissolved antimony ( $\mu \mathrm{g} / \mathrm{L}$ as $\mathrm{Sb})$ & - & - & - & - & $<.200$ & $<.20$ & $<.30$ \\
\hline 01000 & Dissolved arsenic ( $\mu \mathrm{g} / \mathrm{L}$ as As) & - & - & - & - & - & - & $<.26$ \\
\hline 01005 & Dissolved barium ( $\mu \mathrm{g} / \mathrm{L}$ as $\mathrm{Ba})$ & - & - & $<2$ & $<2$ & $<.200$ & $<.20$ & $<.050$ \\
\hline 01010 & Dissolved beryllium ( $\mu \mathrm{g} / \mathrm{L}$ as $\mathrm{Be})$ & - & - & $<.5$ & $<.5$ & $<.2$ & $<.20$ & $<.06$ \\
\hline 01020 & Dissolved boron $(\mu \mathrm{g} / \mathrm{L}$ as $\mathrm{B})$ & - & - & - & - & 4.78 & 3.1 & $<7$ \\
\hline 01025 & Dissolved cadmium ( $\mu \mathrm{g} / \mathrm{L}$ as $\mathrm{Cd})$ & - & - & $<1.0$ & $<1.0$ & $<.3$ & $<.30$ & $<.037$ \\
\hline 01030 & Dissolved chromium ( $\mu \mathrm{g} / \mathrm{L}$ as $\mathrm{Cr})$ & - & - & $<5$ & $<5$ & $<.200$ & $<.20$ & $<.8$ \\
\hline 01035 & Dissolved cobalt ( $\mu \mathrm{g} / \mathrm{L}$ as $\mathrm{Co}$ ) & - & - & $<3$ & $<3$ & $<.200$ & $<.20$ & $<.015$ \\
\hline 01040 & Dissolved copper $(\mu \mathrm{g} / \mathrm{L}$ as $\mathrm{Cu})$ & - & - & $<10$ & $<10$ & 0.23 & .26 & $<.23$ \\
\hline 01046 & Dissolved iron $(\mu \mathrm{g} / \mathrm{L}$ as Fe $)$ & - & - & $<3$ & $<3$ & $<3$ & $<3.0$ & $<10$ \\
\hline 01049 & Dissolved lead $(\mu \mathrm{g} / \mathrm{L}$ as $\mathrm{Pb})$ & - & - & $<10$ & $<10$ & $<.300$ & $<.30$ & $<.08$ \\
\hline 01130 & Dissolved lithium ( $\mu \mathrm{g} / \mathrm{L}$ as $\mathrm{Li})$ & - & - & $<4$ & $<4$ & - & - & $<.50$ \\
\hline 01056 & Dissolved manganese ( $\mu \mathrm{g} / \mathrm{L}$ as $\mathrm{Mn})$ & - & - & $<1$ & $<1$ & $<.100$ & $<.10$ & $<.18$ \\
\hline 01060 & Dissolved molybdenum ( $\mu \mathrm{g} / \mathrm{L}$ as $\mathrm{Mo})$ & - & - & $<10$ & $<10$ & $<.200$ & $<.20$ & $<.33$ \\
\hline 01065 & Dissolved nickel ( $\mu \mathrm{g} / \mathrm{L}$ as $\mathrm{Ni})$ & - & - & $<10$ & $<10$ & $<.500$ & $<.50$ & $<.06$ \\
\hline 01145 & Dissolved selenium ( $\mu \mathrm{g} / \mathrm{L}$ as $\mathrm{Se})$ & - & - & - & - & - & - & $<.50$ \\
\hline 01075 & Dissolved silver ( $\mu \mathrm{g} / \mathrm{L}$ as $\mathrm{Ag})$ & - & - & $<1.0$ & $<1.0$ & $<.2$ & $<.20$ & $<.20$ \\
\hline 01080 & Dissolved strontium ( $\mu \mathrm{g} / \mathrm{L}$ as $\mathrm{Sr})$ & - & - & $<.500$ & $<.500$ & $<.100$ & $<.10$ & $<.20$ \\
\hline 01057 & Dissolved thallium $(\mu \mathrm{g} / \mathrm{L}$ as $\mathrm{Tl})$ & - & - & - & - & $<.100$ & $<.10$ & $<.041$ \\
\hline 01085 & Dissolved vanadium $(\mu \mathrm{g} / \mathrm{L}$ as $\mathrm{V})$ & - & - & $<6$ & $<6$ & - & - & $<.13$ \\
\hline 01090 & Dissolved zinc ( $\mu \mathrm{g} / \mathrm{L}$ as $\mathrm{Zn})$ & - & - & 3 & $<3$ & 1 & $<.50$ & $<1$ \\
\hline 22703 & Dissolved uranium, natural, water, $\mu \mathrm{g} / \mathrm{L}$ & - & - & - & - & $<.20$ & $<.20$ & $<.018$ \\
\hline
\end{tabular}


Table 12. The distribution of concentrations in equipment and trip blank samples and the minimum, median, and maximum values of environmental samples.

$\left[\mathrm{mg} / \mathrm{L}\right.$, milligram per liter; <, less than; —, not enough samples to calculate; N, nitrogen; P, phosphorus; NA, no detection level established; ${ }^{\circ} \mathrm{C}$, degrees Celsius; $\mu \mathrm{g} / \mathrm{L}$, microgram per liter; E, value is estimated below the laboratory detection level]

\begin{tabular}{|c|c|c|c|c|c|c|c|c|c|c|c|c|}
\hline \multirow[b]{3}{*}{ Constituent } & \multirow[b]{3}{*}{$\begin{array}{l}\text { Laboratory } \\
\text { reporting } \\
\text { levels }\end{array}$} & \multicolumn{6}{|c|}{ Blank samples } & \multicolumn{5}{|c|}{ Environmental samples } \\
\hline & & \multirow[b]{2}{*}{$\begin{array}{c}\text { Number } \\
\text { of } \\
\text { obser- } \\
\text { vations }\end{array}$} & \multirow[b]{2}{*}{ Median } & \multirow[b]{2}{*}{$\begin{array}{l}90^{\text {th }} \text { Per- } \\
\text { centile }\end{array}$} & \multicolumn{3}{|c|}{ 95-percent confidence level } & \multirow[b]{2}{*}{$\begin{array}{c}\text { Number } \\
\text { of } \\
\text { obser- } \\
\text { vations }\end{array}$} & \multicolumn{4}{|c|}{ Concentration } \\
\hline & & & & & $\begin{array}{l}\text { Lower } \\
\text { bound of } \\
\text { the } \\
\text { median } \\
\text { confi- } \\
\text { dence } \\
\text { interval }\end{array}$ & $\begin{array}{c}\text { Upper } \\
\text { bound of } \\
\text { the } \\
\text { median } \\
\text { confi- } \\
\text { dence } \\
\text { interval }\end{array}$ & $\begin{array}{c}\text { Upper } \\
\text { bound of } \\
\text { the } 90^{\text {th }} \\
\text { percentile } \\
\text { confidence } \\
\text { interval }\end{array}$ & & Minimum & $\begin{array}{c}10^{\text {th }} \\
\text { per- } \\
\text { centile }\end{array}$ & Median & $\begin{array}{c}90^{\text {th }} \\
\text { per- } \\
\text { centile }\end{array}$ \\
\hline \multicolumn{13}{|c|}{ Major anions and cations } \\
\hline Calcium, mg/L & 0.002 & 73 & 0.004 & 0.04 & 0.003 & 0.006 & 0.069 & 1,442 & 1.9 & 4.7 & 6.8 & 9.7 \\
\hline Magnesium, mg/L & $0.001,0.01$ & 73 & $<0.001$ & 0.004 & $<0.001$ & $<0.01$ & 0.01 & 1,442 & 0.8 & 1.9 & 2.6 & 3.49 \\
\hline Potassium, mg/L & 0.1 & 6 & $<0.1$ & $<0.1$ & $<0.1$ & $<0.1$ & - & 1,442 & 0.1 & 1.4 & 2.4 & 4.2 \\
\hline Sodium, mg/L & $\begin{array}{l}0.025,0.2 \\
\quad 0.03\end{array}$ & 73 & $<0.03$ & 0.041 & $<0.025$ & $<0.03$ & 0.18 & 1,442 & 1.2 & 3.7 & 5.6 & 23 \\
\hline Bicarbonate, mg/L & NA & 6 & 2.55 & 3 & 1.3 & 3 & - & 1,426 & 5.9 & 18 & 28 & 41 \\
\hline Chloride, $\mathrm{mg} / \mathrm{L}$ & 0.1 & 6 & $<0.1$ & 0.1 & $<0.1$ & 0.1 & - & 1,405 & 0.3 & 4.2 & 6.2 & 16 \\
\hline Fluoride, mg/L & 0.1 & 6 & $<0.1$ & $<0.1$ & $<0.1$ & $<0.1$ & - & 1,404 & $<0.1$ & $<0.1$ & $<0.1$ & 0.2 \\
\hline Silica, mg/L & $\begin{array}{l}0.1,0.01 \\
\quad 0.02\end{array}$ & 73 & $<0.02$ & 0.316 & $<0.02$ & $<0.02$ & 0.388 & 1,383 & $<0.1$ & 4.5 & 9.2 & 14 \\
\hline Sulfate, mg/L & 0.1 & 6 & $<0.1$ & 0.3 & $<0.1$ & 0.3 & - & 1,401 & $<0.1$ & 3 & 6.4 & 24 \\
\hline \multicolumn{13}{|c|}{ Nutrients, organic carbon, and physical measures } \\
\hline $\begin{array}{l}\text { Dissolved organic nitrogen plus ammo- } \\
\text { nia, } \mathrm{mg} / \mathrm{L} \text { as } \mathrm{N}\end{array}$ & $0.1,0.2$ & 24 & $<0.2$ & $<0.2$ & $<0.2$ & $<0.2$ & $<0.2$ & 1,068 & $<0.1$ & $<0.2$ & 0.4 & 0.7 \\
\hline $\begin{array}{l}\text { Total organic nitrogen plus ammonia, } \\
\mathrm{mg} / \mathrm{L} \text { as } \mathrm{N}\end{array}$ & $0.1,0.2$ & 23 & $<0.2$ & $<0.2$ & $<0.2$ & $<0.2$ & 0.3 & 1,566 & $<0.1$ & 0.3 & 0.6 & 1.0 \\
\hline Ammonia, $\mathrm{mg} / \mathrm{L}$ as $\mathrm{N}$ & 0.002 & 92 & $<0.002$ & 0.02 & $<0.002$ & 0.002 & 0.03 & 1,478 & $<0.002$ & 0.009 & 0.04 & 0.14 \\
\hline Nitrite plus nitrate, $\mathrm{mg} / \mathrm{L}$ as $\mathrm{N}$ & $0.05,0.005$ & 92 & $<0.005$ & 0.005 & $<0.005$ & $<0.005$ & 0.008 & 1,499 & $<0.005$ & $<0.05$ & 0.23 & 0.95 \\
\hline Nitrite, $\mathrm{mg} / \mathrm{L}$ as $\mathrm{N}$ & $0.001,0.01$ & 92 & $<0.001$ & $<0.003$ & $<0.001$ & $<0.001$ & 0.01 & 1,220 & $<0.001$ & $<0.01$ & $<0.01$ & 0.02 \\
\hline Dissolved phosphorus, $\mathrm{mg} / \mathrm{L}$ as $\mathrm{P}$ & 0.01 & 24 & $<0.01$ & 0.01 & $<0.01$ & $<0.01$ & 0.02 & 1,093 & $<0.01$ & $<0.01$ & 0.02 & 0.128 \\
\hline Orthophosphate, $\mathrm{mg} / \mathrm{L}$ as $\mathrm{P}$ & $0.001,0.01$ & 92 & 0.001 & 0.003 & $<0.001$ & 0.001 & 0.008 & 1,478 & $<0.001$ & $<0.01$ & $<0.01$ & 0.1 \\
\hline Total phosphorus, $\mathrm{mg} / \mathrm{L}$ as $\mathrm{P}$ & 0.01 & 23 & $<0.01$ & 0.02 & $<0.01$ & 0.01 & 0.04 & 1,545 & $<0.01$ & 0.02 & 0.05 & 0.18 \\
\hline Total organic carbon, mg/L & NA & 6 & 0.25 & 6.9 & 0.1 & 6.9 & - & 1,418 & 0.8 & 4.2 & 7.2 & 12 \\
\hline Color & 1 & 6 & 3 & 5 & 1 & 5 & - & 1,417 & $<1$ & 19 & 45 & 110 \\
\hline Dissolved residue, evaporation at $180^{\circ} \mathrm{C}$ & 1 & 6 & $<1$ & 2 & $<1$ & 2 & - & 1,381 & $<1$ & 48 & 70 & 120 \\
\hline
\end{tabular}


Table 12. The distribution of concentrations in equipment and trip blank samples and the minimum, median, and maximum values of environmental samples.-Continued

[mg/L, milligram per liter; <, less than; —, not enough samples to calculate; N, nitrogen; P, phosphorus; NA, no detection level established; ${ }^{\circ} \mathrm{C}$, degrees Celsius; $\mu \mathrm{g} / \mathrm{L}$, microgram per liter; E, value is estimated below the laboratory detection level]

\begin{tabular}{|c|c|c|c|c|c|c|c|c|c|c|c|c|}
\hline \multirow[b]{3}{*}{ Constituent } & \multirow[b]{3}{*}{$\begin{array}{l}\text { Laboratory } \\
\text { reporting } \\
\text { levels }\end{array}$} & \multicolumn{6}{|c|}{ Blank samples } & \multicolumn{5}{|c|}{ Environmental samples } \\
\hline & & \multirow[b]{2}{*}{$\begin{array}{c}\text { Number } \\
\text { of } \\
\text { obser- } \\
\text { vations }\end{array}$} & \multirow[b]{2}{*}{ Median } & \multirow[b]{2}{*}{$\begin{array}{c}90^{\text {th }} \text { Per- } \\
\text { centile }\end{array}$} & \multicolumn{3}{|c|}{ 95-percent confidence level } & \multirow[b]{2}{*}{$\begin{array}{c}\text { Number } \\
\text { of } \\
\text { obser- } \\
\text { vations }\end{array}$} & \multicolumn{4}{|c|}{ Concentration } \\
\hline & & & & & $\begin{array}{l}\text { Lower } \\
\text { bound of } \\
\text { the } \\
\text { median } \\
\text { confi- } \\
\text { dence } \\
\text { interval }\end{array}$ & $\begin{array}{c}\text { Upper } \\
\text { bound of } \\
\text { the } \\
\text { median } \\
\text { confi- } \\
\text { dence } \\
\text { interval }\end{array}$ & $\begin{array}{l}\text { Upper } \\
\text { bound of } \\
\text { the } 90^{\text {th }} \\
\text { percentile } \\
\text { confidence } \\
\text { interval }\end{array}$ & & Minimum & $\begin{array}{c}10^{\text {th }} \\
\text { per- } \\
\text { centile }\end{array}$ & Median & $\begin{array}{c}90^{\text {th }} \\
\text { per- } \\
\text { centile }\end{array}$ \\
\hline \multicolumn{13}{|c|}{ Metals and trace elements } \\
\hline Total aluminum, $\mu \mathrm{g} / \mathrm{L}$ & 10 & 22 & $<10$ & 10 & $<10$ & $<10$ & 40 & 804 & $<10$ & 40 & 140 & 1,200 \\
\hline Dissolved aluminum, $\mu \mathrm{g} / \mathrm{L}$ & 0.3 & 67 & $<0.3$ & 2.7 & $<0.3$ & $<0.3$ & 3.5 & - & - & - & - & - \\
\hline Total arsenic, $\mu \mathrm{g} / \mathrm{L}$ & 1 & 22 & $<1$ & $<1$ & $<1$ & $<1$ & $<1$ & 813 & $<1$ & $<1$ & $<1$ & 2 \\
\hline Total cadmium, $\mu \mathrm{g} / \mathrm{L}$ & 1 & 22 & $<1$ & $<1$ & $<1$ & $<1$ & $<1$ & 823 & E0.05 & $<1$ & $<1$ & $<1$ \\
\hline Dissolved cadmium, $\mu \mathrm{g} / \mathrm{L}$ & 0.3 & 67 & $<0.3$ & $<0.3$ & $<0.3$ & $<0.3$ & $<0.3$ & - & - & - & - & - \\
\hline Total chromium, $\mu \mathrm{g} / \mathrm{L}$ & 1 & 22 & $<1$ & $<1$ & $<1$ & $<1$ & 6 & 823 & E0.5 & $<1$ & $<1$ & 3 \\
\hline Dissolved chromium, $\mu \mathrm{g} / \mathrm{L}$ & 0.2 & 67 & $<0.2$ & $<0.2$ & $<0.2$ & $<0.2$ & 0.245 & - & - & - & - & - \\
\hline Total cobalt, $\mu \mathrm{g} / \mathrm{L}$ & 1 & 22 & $<1$ & $<1$ & $<1$ & $<1$ & $<1$ & 805 & $<1$ & $<1$ & $<1$ & 2 \\
\hline Dissolved cobalt, $\mu \mathrm{g} / \mathrm{L}$ & 0.2 & 67 & $<0.2$ & $<0.2$ & $<0.2$ & $<0.2$ & $<0.2$ & - & - & - & - & - \\
\hline Total copper, $\mu \mathrm{g} / \mathrm{L}$ & 1 & 22 & $<1$ & 1 & $<1$ & $<1$ & 2 & 798 & E0.7 & $<1$ & 2 & 6 \\
\hline Dissolved copper, $\mu \mathrm{g} / \mathrm{L}$ & 0.2 & 67 & $<0.2$ & 0.57 & $<0.2$ & $<0.2$ & 1.406 & - & - & - & - & - \\
\hline Total iron, $\mu \mathrm{g} / \mathrm{L}$ & 10 & 22 & $<10$ & 20 & $<10$ & $<10$ & 20 & 963 & $<10$ & 150 & 580 & 2,300 \\
\hline Dissolved iron, $\mu \mathrm{g} / \mathrm{L}$ & 3 & 67 & $<3$ & $<3$ & $<3$ & $<3$ & 4.36 & - & - & - & - & - \\
\hline Total lead, $\mu \mathrm{g} / \mathrm{L}$ & 1 & 22 & $<1$ & $<1$ & $<1$ & $<1$ & $<1$ & 798 & E0.6 & $<1$ & $<1$ & 5 \\
\hline Dissolved lead, $\mu \mathrm{g} / \mathrm{L}$ & 0.3 & 67 & $<0.3$ & $<0.3$ & $<0.3$ & $<0.3$ & $<0.3$ & - & - & - & - & - \\
\hline Total manganese, $\mu \mathrm{g} / \mathrm{L}$ & 10 & 22 & $<10$ & $<10$ & $<10$ & $<10$ & $<10$ & 962 & $<10$ & 40 & 130 & 670 \\
\hline Dissolved manganese, $\mu \mathrm{g} / \mathrm{L}$ & $0.1,1$ & 67 & $<0.1$ & 0.162 & $<0.1$ & $<0.1$ & 0.376 & - & - & - & - & - \\
\hline Total mercury, $\mu \mathrm{g} / \mathrm{L}$ & 0.1 & 22 & $<0.1$ & $<0.1$ & $<0.1$ & $<0.1$ & 0.6 & 815 & $<0.1$ & $<0.1$ & $<0.1$ & $<0.1$ \\
\hline Total molybdenum, $\mu \mathrm{g} / \mathrm{L}$ & 1 & 22 & $<1$ & $<1$ & $<1$ & $<1$ & 1 & 789 & E0.9 & $<1$ & $<1$ & 2 \\
\hline Dissolved molybdenum, $\mu \mathrm{g} / \mathrm{L}$ & $0.2,10$ & 67 & $<0.2$ & $<0.2$ & $<0.2$ & $<0.2$ & $<0.2$ & - & - & - & - & - \\
\hline Total nickel, $\mu \mathrm{g} / \mathrm{L}$ & 1 & 20 & $<1$ & 2 & $<1$ & $<1$ & - & 794 & E0.9 & $<1$ & $<1$ & 3 \\
\hline Dissolved nickel, $\mu \mathrm{g} / \mathrm{L}$ & $0.5,10$ & 67 & $<0.5$ & $<0.5$ & $<0.5$ & $<0.5$ & 0.582 & - & - & - & - & - \\
\hline Total selenium, $\mu \mathrm{g} / \mathrm{L}$ & 1 & 22 & $<1$ & $<1$ & $<1$ & $<1$ & $<1$ & 805 & $<1$ & $<1$ & $<1$ & $<1$ \\
\hline Total silver, $\mu \mathrm{g} / \mathrm{L}$ & 1 & 22 & $<1$ & $<1$ & $<1$ & $<1$ & $<1$ & 803 & $<0.4$ & $<1$ & $<1$ & $<1$ \\
\hline Dissolved silver, $\mu \mathrm{g} / \mathrm{L}$ & $0.2,1$ & 67 & $<0.2$ & $<0.2$ & $<0.2$ & $<0.2$ & $<0.2$ & - & - & - & - & - \\
\hline Total zinc, $\mu \mathrm{g} / \mathrm{L}$ & 10 & 22 & $<10$ & $<10$ & $<10$ & $<10$ & 10 & 807 & $<10$ & $<10$ & $<10$ & 31 \\
\hline Dissolved zinc, $\mu \mathrm{g} / \mathrm{L}$ & 0.5 & 67 & 0.565 & 2.204 & $<0.5$ & 0.71 & 4.813 & - & - & - & - & - \\
\hline
\end{tabular}


Table 12. The distribution of concentrations in equipment and trip blank samples and the minimum, median, and maximum values of environmental samples.-Continued

[mg/L, milligram per liter; <, less than; —, not enough samples to calculate; N, nitrogen; P, phosphorus; NA, no detection level established; ${ }^{\circ} \mathrm{C}$, degrees Celsius; $\mu \mathrm{g} / \mathrm{L}$, microgram per liter; E, value is estimated below the laboratory detection level]

\begin{tabular}{|c|c|c|c|c|c|c|c|c|c|c|c|c|}
\hline \multirow[b]{3}{*}{ Constituent } & \multirow[b]{3}{*}{$\begin{array}{c}\text { Laboratory } \\
\text { reporting } \\
\text { levels }\end{array}$} & \multicolumn{6}{|c|}{ Blank samples } & \multicolumn{5}{|c|}{ Environmental samples } \\
\hline & & \multirow[b]{2}{*}{$\begin{array}{c}\text { Number } \\
\text { of } \\
\text { obser- } \\
\text { vations }\end{array}$} & \multirow[b]{2}{*}{ Median } & \multirow[b]{2}{*}{$\begin{array}{c}90^{\text {th }} \text { Per- } \\
\text { centile }\end{array}$} & \multicolumn{3}{|c|}{ 95-percent confidence level } & \multirow[b]{2}{*}{$\begin{array}{c}\text { Number } \\
\text { of } \\
\text { obser- } \\
\text { vations }\end{array}$} & \multicolumn{4}{|c|}{ Concentration } \\
\hline & & & & & $\begin{array}{l}\text { Lower } \\
\text { bound of } \\
\text { the } \\
\text { median } \\
\text { confi- } \\
\text { dence } \\
\text { interval }\end{array}$ & $\begin{array}{l}\text { Upper } \\
\text { bound of } \\
\text { the } \\
\text { median } \\
\text { confi- } \\
\text { dence } \\
\text { interval }\end{array}$ & $\begin{array}{c}\text { Upper } \\
\text { bound of } \\
\text { the } 90^{\text {th }} \\
\text { percentile } \\
\text { confidence } \\
\text { interval }\end{array}$ & & Minimum & $\begin{array}{c}10^{\text {th }} \\
\text { per- } \\
\text { centile }\end{array}$ & Median & $\begin{array}{c}90^{\text {th }} \\
\text { per- } \\
\text { centile }\end{array}$ \\
\hline \multicolumn{13}{|c|}{ Metals and trace elements with no associated environmental data } \\
\hline Antimony, dissolved, $\mu \mathrm{g} / \mathrm{L}$ & 0.2 & 67 & $<0.2$ & $<0.2$ & $<0.2$ & $<0.2$ & $<0.2$ & - & - & - & - & - \\
\hline Barium, dissolved, $\mu \mathrm{g} / \mathrm{L}$ & 0.2 & 67 & $<0.2$ & $<0.2$ & $<0.2$ & $<0.2$ & $<0.2$ & - & - & - & - & - \\
\hline Beryllium, dissolved, $\mu \mathrm{g} / \mathrm{L}$ & 0.2 & 67 & $<0.2$ & $<0.2$ & $<0.2$ & $<0.2$ & $<0.2$ & - & - & - & - & - \\
\hline Boron, dissolved, $\mu \mathrm{g} / \mathrm{L}$ & 2 & 67 & $<2$ & 6.8 & $<2$ & $<2$ & 7.7 & - & - & - & - & - \\
\hline Strontium dissolved, $\mu \mathrm{g} / \mathrm{L}$ & 0.1 & 67 & $<0.1$ & $<0.1$ & $<0.1$ & $<0.1$ & 0.157 & - & - & - & - & - \\
\hline Titanium, dissolved, $\mu \mathrm{g} / \mathrm{L}$ & 0.1 & 67 & $<0.1$ & $<0.1$ & $<0.1$ & $<0.1$ & $<0.1$ & - & - & - & - & - \\
\hline Uranium, $\mu \mathrm{g} / \mathrm{L}$ & 0.2 & 67 & $<0.2$ & $<0.2$ & $<0.2$ & $<0.2$ & $<0.2$ & - & - & - & - & - \\
\hline
\end{tabular}

Uranium, $\mu \mathrm{g} / \mathrm{L}$

0.2 


\section{Triangle Area Water Supply Monitoring Project, October 1988-September 2001, North Carolina}

Graphs of selected major ion concentrations in blank samples over time suggest that changing to the parts-per-billion protocol (fig. 6) in 1994 probably resulted in improved sample handling and a decrease in blank sample contamination. Note that detection levels for sodium, potassium, and silica were lowered in 1993.

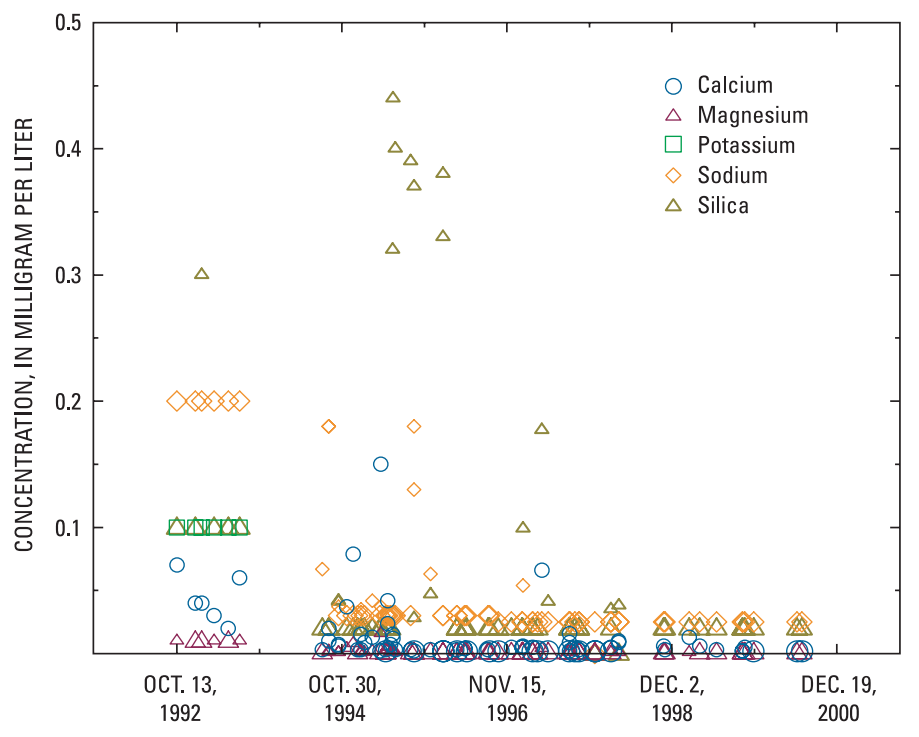

Figure 6. Concentrations of selected major ions in trip and equipment blanks during the period of study for the Triangle Area Water Supply Monitoring Project in North Carolina.

For most nutrients, the upper bound for the 95-percent confidence interval of the $90^{\text {th }}$ percentile concentration of the blank samples was greater than the laboratory detection level (except for dissolved organic nitrogen plus ammonia). Furthermore, nutrient concentrations in the environmental samples were very low; for dissolved organic-plus-ammonia nitrogen, nitrite plus nitrate, nitrite, dissolved phosphorus, and orthophosphate, the $10^{\text {th }}$ percentile concentration of the environmental samples was at the detection level. As a result, contamination of the environmental samples from sample collection and processing is possible but only for samples with very low concentrations. Blank concentrations over time suggest that improvements in sample handling in 1994 resulted in decreased blank sample contamination (fig. 7). Note that laboratory reporting levels for most nutrients were lowered in October 1994.

Few blank samples were analyzed for color, total organic carbon, and dissolved residue; thus, the upper bound of the

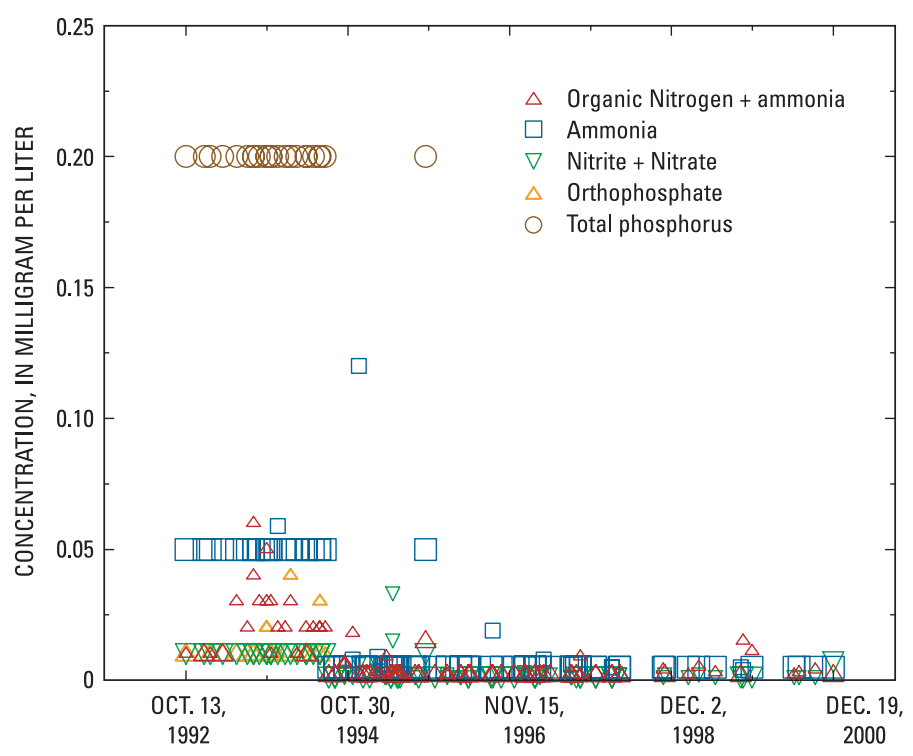

Figure 7. Concentrations of selected nutrients in equipment and trip blanks during the period of study for the Triangle Area Water Supply Monitoring Project in North Carolina.

95-percent confidence interval of the $90^{\text {th }}$ percentile concentration could not be determined. For color and dissolved residue, the $90^{\text {th }}$ percentile concentration of the blank samples was at least four times less than the $10^{\text {th }}$ percentile concentration of the environmental samples. For total organic carbon, the $90^{\text {th }}$ percentile concentration of the blank samples slightly exceeded the $10^{\text {th }}$ percentile of the environmental samples. This indicates that contamination from sample handling may have been significant at the concentrations found in the environmental samples. Only one blank sample, however, had a concentration greater than $1.6 \mathrm{mg} / \mathrm{L}$, and this sample was the first blank sample collected for total organic carbon in 1992.

For total metals and trace elements, 77 to 100 percent of the concentrations in the blank samples were below the laboratory reporting level (table 13); for dissolved metals and trace elements, between 46 and 100 percent were below the laboratory reporting level. The greatest potential for sample contamination (that is, the upper bound of the 95-percent confidence interval of the $90^{\text {th }}$ percentile concentration for blanks was above the detection level and greater than the $10^{\text {th }}$ percentile of the environmental samples) was for total aluminum, total chromium, total copper, and total mercury (table 12).

Analyses of blank samples, however, collected only after 1994 with lower reporting levels for dissolved aluminum and 
Table 13. The percentage of blank samples that were analyzed for metals and trace elements with concentrations above the detection level.

[ $\mu \mathrm{g} / \mathrm{L}$, microgram per liter]

\begin{tabular}{|c|c|c|c|}
\hline $\begin{array}{c}\text { Metal } \\
\text { or } \\
\text { trace element }\end{array}$ & $\begin{array}{c}\text { Detection } \\
\text { level, in } \\
\mu \mathrm{g} / \mathrm{L}\end{array}$ & $\begin{array}{l}\text { Number } \\
\text { of } \\
\text { analyses }\end{array}$ & $\begin{array}{l}\text { Analyses } \\
\text { less than } \\
\text { detection, } \\
\text { in percent }\end{array}$ \\
\hline Total aluminum & 10 & 22 & 77 \\
\hline Dissolved aluminum & 0.3 & 67 & 75 \\
\hline Total arsenic & 1 & 22 & 100 \\
\hline Total cadmium & 1 & 22 & 100 \\
\hline Dissolved cadmium & 0.3 & 67 & 100 \\
\hline Total chromium & 1 & 22 & 95 \\
\hline Dissolved chromium & 0.2 & 67 & 94 \\
\hline Total cobalt & 1 & 22 & 100 \\
\hline Dissolved cobalt & 0.2 & 67 & 100 \\
\hline Total copper & 1 & 22 & 82 \\
\hline Dissolved copper & 0.2 & 67 & 73 \\
\hline Total iron & 10 & 22 & 77 \\
\hline Dissolved iron & 3 & 67 & 91 \\
\hline Total lead & 1 & 22 & 100 \\
\hline Dissolved lead & 1 & 22 & 100 \\
\hline Total manganese & 10 & 22 & 100 \\
\hline Dissolved manganese & 0.1 & 67 & 81 \\
\hline Total mercury & 0.1 & 22 & 91 \\
\hline Total molybdenum & 1 & 22 & 91 \\
\hline Dissolved molybdenum & 0.2 & 67 & 100 \\
\hline Total nickel & 1 & 20 & 85 \\
\hline Dissolved nickel & 0.5 & 67 & 94 \\
\hline Total selenium & 1 & 22 & 100 \\
\hline Total silver & 1 & 22 & 100 \\
\hline Dissolved silver & 0.2 & 67 & 100 \\
\hline Total zinc & 10 & 22 & 95 \\
\hline Dissolved zinc & 0.5 & 67 & 46 \\
\hline
\end{tabular}

dissolved chromium indicate that contamination from samplecollection and handling procedures was not significant. For these blank samples, the upper bound of the 95-percent confidence interval of the $90^{\text {th }}$ percentile concentrations for dissolved aluminum and dissolved chromium in blanks was
3.5 and $0.245 \mu \mathrm{g} / \mathrm{L}$, respectively. The improvement in blank contaminant levels relative to concentrations in environmental samples is a result, in part, of the decrease in reporting levels and also may be due to the adoption of improved sample-collection and handling protocols in 1994. Likewise, iron and aluminum concentrations in blank samples have decreased during the study, and this decrease suggests that improvements in sample handling implemented in 1994 resulted in decreased blank sample contamination (fig. 8).

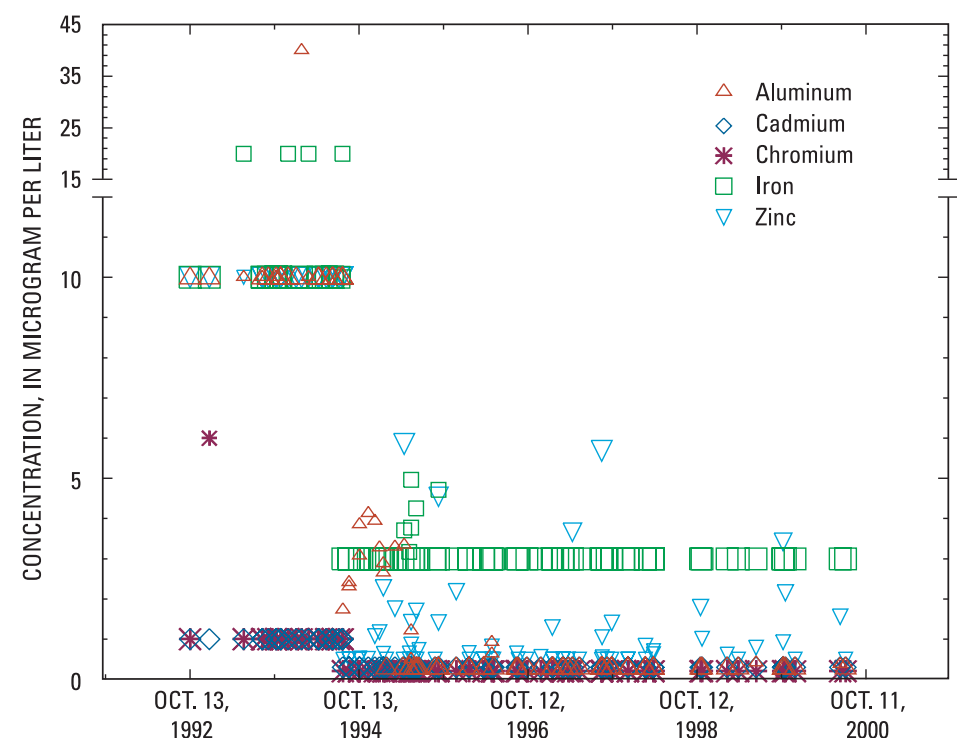

Figure 8. Concentrations of selected metals and trace elements in equipment and trip blanks during the period of study for the Triangle Area Water Supply Monitoring Project in North Carolina.

Concentrations in equipment blanks were compared to concentrations in trip blanks to assess whether contamination was most likely a result of sample-collection and processing procedures or procedures associated with the handling of containers during transport. For selected major ions and nutrients, contamination was most often found in equipment blanks (fig. 9). Similarly, a greater range of concentrations of selected metals and trace elements occurred in equipment blanks (fig. 10). Zinc and aluminum were exceptions to this. 


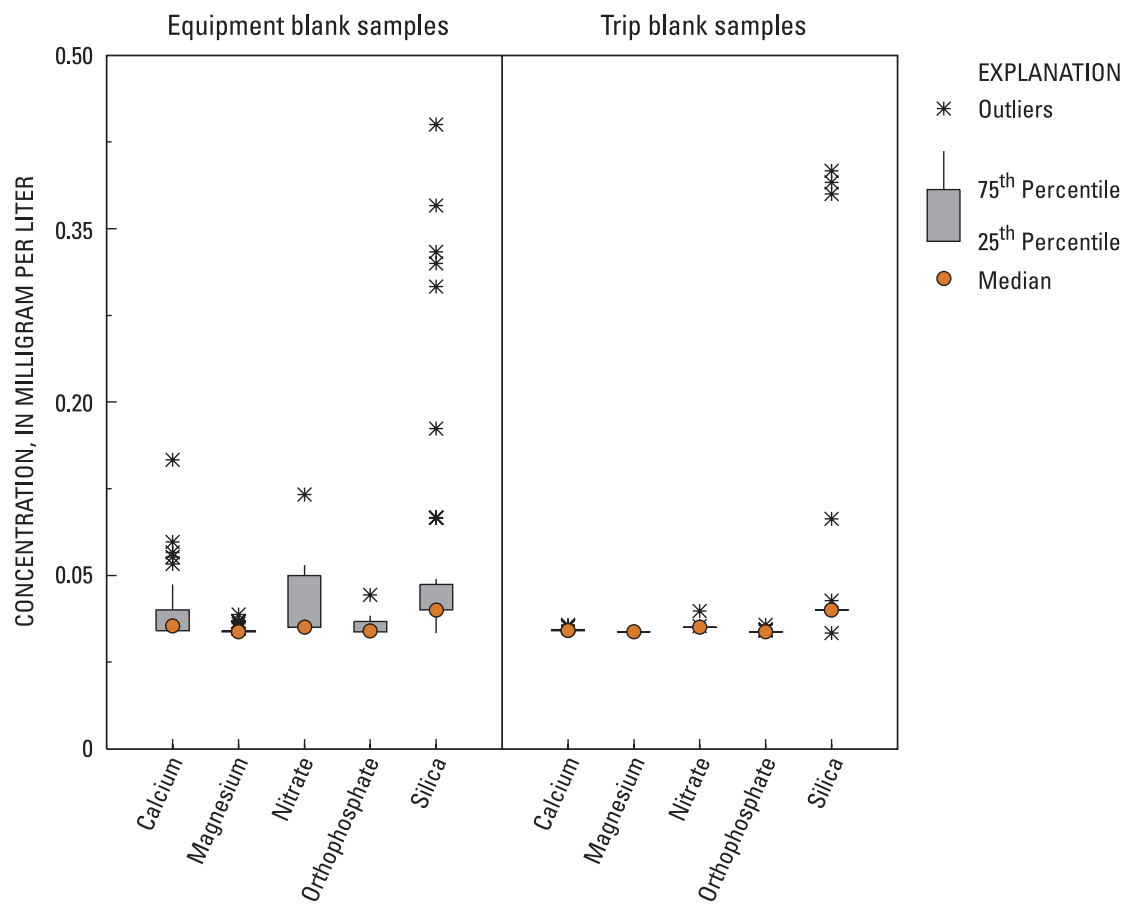

Figure 9. Distribution of concentrations of calcium, magnesium, nitrate, orthophosphate, and silica in equipment blanks and trip blanks for the Triangle Area Water Supply Monitoring Project in North Carolina.



Figure 10. Distribution of dissolved concentrations of aluminum, cadmium, chromium, copper, iron, manganese, nickel, lead, and zinc in equipment blanks and trip blanks for the Triangle Area Water Supply Monitoring Project in North Carolina. 


\section{Replicates}

Two types of replicate samples were collected-split and concurrent replicate samples. Split samples were obtained by splitting a single sample into two sample bottles and assigning each a unique time of sample collection (typically 1 to 5 minutes apart). Concurrent samples were collected from the stream or lake separately but at approximately the same time. Each sample then was assigned a unique time of sample collection (typically 1 to 5 minutes apart).

Analysis of replicate sample results is used as a measure of the variability inherent in the processing and analysis of waterquality samples. Variability was calculated by determining the standard deviation and relative standard deviation of each replicate pair using the following equations:

$$
s=\sqrt{\frac{\left(C_{1}-C_{2}\right)^{2}}{2}},
$$

where

$s$ is the standard deviation of the replicates, and $C_{1}$ and $C_{2}$ are replicate concentrations;

$$
\operatorname{rsd}=100\left(\frac{\mathrm{s}}{\overline{\mathrm{C}}}\right)
$$

where

rsd is the relative standard deviation of the replicates, $s$ is the standard deviation of the replicates, and

$\overline{\mathrm{C}}$ is the average concentration.

The standard deviation of each replicate pair was compared to mean concentration of the replicate pair to assess whether variability changed with concentration. When variability was relatively constant over the range of measured concentrations, variability was expressed as standard deviation. When variability was not constant, variability was expressed as relative standard deviation.

For cadmium, mercury, selenium, and silver, all replicate concentrations were below the detection level. For arsenic, four of five concentrations that were reported as detectable were reported at the detection level (table 14). Variability could not be assessed for these constituents.

Table 14. Replicate variability for total metals and total trace elements.

[Concentrations are in micrograms per liter; $\leq$, less than or equal to; \pm , plus or minus; - , could not be computed

\begin{tabular}{|c|c|c|c|c|c|}
\hline Constituent & $\begin{array}{c}\text { Number of } \\
\text { observations }\end{array}$ & $\begin{array}{l}\text { Number } \\
\text { above } \\
\text { detection }\end{array}$ & $\begin{array}{l}\text { Concentration } \\
\text { range }\end{array}$ & $\begin{array}{c}\text { Standard } \\
\text { deviation or } \\
\text { relative } \\
\text { standard } \\
\text { deviation }\end{array}$ & $\begin{array}{l}90 \text {-percent } \\
\text { confidence } \\
\text { interval for a } \\
\text { result within } \\
\text { range }\end{array}$ \\
\hline Aluminum & 45 & 45 & $\leq 2,300$ & 20.8 & \pm 34.1 \\
\hline Arsenic $^{\mathrm{a}}$ & 45 & 5 & - & - & - \\
\hline Cadmium & 48 & 0 & - & - & - \\
\hline Chromium & 48 & 6 & $>1,<4$ & 0.10 & \pm 0.16 \\
\hline Cobalt & 45 & 6 & $>1,<4$ & 0.02 & \pm 0.03 \\
\hline Copper & 48 & 40 & $<6$ & 0.26 & \pm 0.43 \\
\hline Iron & 48 & 48 & $\leq 3,300$ & 30.4 & \pm 49.8 \\
\hline Lead & 47 & 17 & $>1$ to 5 & 0.11 & \pm .18 \\
\hline Manganese & 48 & 48 & $<6,000$ & 17.32 & \pm 28.5 \\
\hline Mercury & 48 & 0 & - & - & - \\
\hline Molybdenum & 45 & 9 & $>1,<4$ & 0.04 & \pm 0.06 \\
\hline Nickel & 47 & 18 & $>1,<4$ & 0.12 & \pm 0.20 \\
\hline Selenium & 45 & 0 & - & - & - \\
\hline Silver & 48 & 0 & - & - & - \\
\hline Zinc & 48 & 4 & $>10,<40$ & 0.17 & \pm 0.29 \\
\hline
\end{tabular}
because all concentrations were below the detection level; $>$, greater than; $<$, less than]

${ }^{\mathrm{a}} \mathrm{All}$ but one arsenic concentration were at the detection level. 


\section{Triangle Area Water Supply Monitoring Project, October 1988-September 2001, North Carolina}

For total organic carbon and chlorophyll $a$ and $b$, standard deviation was relatively constant at low ranges but increased with increasing concentration at high ranges. For these constituents, variability is expressed as a relative concentration, in percent, for the high ranges (table 15).

The 90-percent confidence interval for a result, shown in tables 14 and 15, indicate the accuracy of a particular result within range. These data can be used to assess whether differences in results for environmental data, either at different sites or at different times at the same site, are significant.

\section{Laboratory Quality Assurance and Quality Control}

The general quality-assurance practices used by the NWQL are described in Friedman and Erdmann (1982), Pritt and Raese (1992), and Pirkey and Glodt (1998). Three elements compose quality control at the NWQL_method performance, data review and blind sample programs, and performanceevaluation studies. Quality-control samples to determine method performance are prepared and analyzed by the chemist. The chemist uses these data to control the analytical process for each batch of environmental samples. If acceptance criteria are not met, then the analysis is discontinued until the problem is corrected. The NWQL Quality Assurance Section provides data review and monitors long-term method performance throughout the laboratory. Results from the blind sample programs, described below, also are used in monitoring longterm method performance. Finally, the NWQL participates in performance-evaluation studies managed by external agencies to compare NWQL performance to other laboratories.

\section{Method-Performance Checks}

Laboratory blank, standard, and replicate samples are among the tools used to monitor and correct the performance of an analytical method. For inorganic analyses, laboratory quality control for each sample set consists of blanks, calibration standards, standard reference samples, and replicate environmental samples. The laboratory blank is prepared from water free of inorganic constituents being measured. Calibration standards are prepared and analyzed at a range of concentrations similar to the range expected in the environmental samples. Standard reference samples are samples of known concentration that are used to assess bias for each analysis and are used for assessment of long-term method performance.

For organic analysis, laboratory quality control for each sample set consists of laboratory reagent blanks, reagent spikes, and surrogate compounds. The laboratory reagent blank is prepared with water that is known to be free of the compounds being analyzed. If, in a sample set, a compound is detected in the blank, the source of contamination is sought and the set of samples is reanalyzed. If the source is not determined, then the detection level for the analyte is increased to the concentration of the reagent blank. The laboratory reagent spike has a known concentration of compounds of interest. The results of analysis are compared with acceptance criteria for the analysis to assess potential bias. Results also are tracked on a long-term basis to monitor long-term trends in bias and variability. A surrogate is a compound that is not expected to be in the environmental sample but on which the method performs similarly. When added to each environmental and quality-control sample, a surrogate is used to assess recovery of the compound. Paper copies of results of blank, spike, and surrogate analyses for sample sets that included project samples were provided by the laboratory and stored in project files.

\section{Blind Sample Program}

The NWQL has two inorganic blind sample programs. One is an internally administered program to quantify bias from laboratory contamination. The Inorganic Blind Sample Project (IBSP) of the USGS Branch of Quality Systems provides independent, external quality assurance for the NWQL. The Branch of Quality Systems produces double-blind qualitycontrol samples that are submitted to the laboratory through USGS District offices. A double-blind sample is a sample for which the sample origin and constituent concentration of the sample are unknown to the analyst.

Samples are made from USGS standard reference samples to appear to the laboratory analyst to be as much like environmental samples as possible. They are subject to the same laboratory handling, processing, and analytical procedures as samples collected for the Triangle Area Water Supply Monitoring Project. The Branch of Quality Systems evaluates the analytical results by comparing the value reported by the laboratory to the most probable value (MPV) for the IBSP sample. The MPV is the median of results for each constituent reported by participants in a round-robin evaluation of USGS standard reference samples. The NWQL results are considered acceptable if they are within 2 standard deviations of the MPV.

Quality-control data from the IBSP can be used to assess laboratory error during specific periods of time. Most importantly, the information is used to assist the laboratory in detecting and correcting problems in analytical procedures (U.S. Geological Survey, 1997-present). Monthly IBSP reports are provided to USGS offices regarding NWQL performance based on blind-sample results. In addition, the IBSP reports include the corrective actions taken by the laboratory. 
Table 15. Replicate variability for physical measurements, major ions, nutrients, and chlorophyll.

[Concentrations are in milligrams per liter unless otherwise noted; <, less than; \pm , plus or minus; $\mu \mathrm{S} / \mathrm{cm}$, microsiemens per centimeter at 25 degrees Celsius; $\leq$, less than or equal to; >, greater than; $\mathrm{ANC}$ as $\mathrm{CaCO}_{3}$, acid neutralizing capacity as calcium carbonate; $\mathrm{NH}_{4}$, ammonia; $\mathrm{N}$, nitrogen; $\mathrm{TKN}$, organic nitrogen plus ammonia; $\mathrm{NO}_{2}$, nitrite; $\mathrm{NO}_{3}$, nitrate; $\mathrm{P}$, phosphorus; $\mathrm{PO}_{4}$, orthophosphate; $\mu \mathrm{g} / \mathrm{L}$, microgram per liter]

\begin{tabular}{|c|c|c|c|c|c|}
\hline Constituent & $\begin{array}{c}\text { Number } \\
\text { of } \\
\text { obser- } \\
\text { vations }\end{array}$ & $\begin{array}{c}\text { Number } \\
\text { above } \\
\text { detection }\end{array}$ & $\begin{array}{c}\text { Concen- } \\
\text { tration } \\
\text { range }\end{array}$ & $\begin{array}{c}\text { Standard } \\
\text { deviation or } \\
\text { relative } \\
\text { standard } \\
\text { deviation }\end{array}$ & $\begin{array}{l}90 \text {-percent } \\
\text { confidence } \\
\text { interval for a } \\
\text { result within } \\
\text { range }\end{array}$ \\
\hline Laboratory $\mathrm{pH}$, standard units & 96 & 96 & $<10$ & 0.10 & \pm 0.16 \\
\hline Specific conductance, $\mu \mathrm{S} / \mathrm{cm}$ & 96 & 96 & $<500$ & 0.78 & \pm 1.3 \\
\hline Calcium & 96 & 96 & $<30$ & 0.08 & \pm 0.13 \\
\hline Magnesium & 96 & 96 & $<6$ & 0.04 & \pm 0.06 \\
\hline Potassium & 96 & 96 & $<18$ & 0.06 & \pm 0.10 \\
\hline \multirow[t]{2}{*}{ Sodium } & 75 & 75 & $\leq 10$ & 0.06 & \pm 0.10 \\
\hline & 21 & 21 & $>10$ to 65 & 0.38 & \pm 0.62 \\
\hline $\mathrm{ANC}$ as $\mathrm{CaCO}_{3}$ & 96 & 96 & $<50$ & 0.27 & \pm 0.24 \\
\hline Chloride & 92 & 92 & $\leq 44$ & 0.16 & \pm 0.26 \\
\hline Fluoride & 92 & 49 & $<0.4$ & 0.01 & \pm 0.02 \\
\hline Silica & 89 & 89 & $<20$ & 0.24 & \pm 0.39 \\
\hline Sulfate & 92 & 92 & $<100$ & 0.17 & \pm 0.28 \\
\hline Dissolved $\mathrm{NH}_{4}$ as $\mathrm{N}$ & 94 & 78 & $<3.0$ & 0.004 & \pm 0.006 \\
\hline Total $\mathrm{NH}_{4}$ as $\mathrm{N}$ & 25 & 22 & $<3.0$ & 0.004 & \pm 0.006 \\
\hline Dissolved TKN as $\mathrm{N}$ & 78 & 70 & $<2.0$ & 0.05 & \pm 0.08 \\
\hline Total TKN as $\mathrm{N}$ & 95 & 85 & $<2.0$ & 0.06 & \pm 0.10 \\
\hline Dissolved $\mathrm{NO}_{2}+\mathrm{NO}_{3}$ as $\mathrm{N}$ & 94 & 72 & $<3.0$ & 0.02 & \pm 0.03 \\
\hline Total $\mathrm{NO}_{2}+\mathrm{NO}_{3}$ as $\mathrm{N}$ & 25 & 18 & $<3.0$ & 0.02 & \pm 0.03 \\
\hline Dissolved $\mathrm{NO}_{2}$ as $\mathrm{N}$ & 82 & 41 & $<0.12$ & 0.001 & \pm 0.002 \\
\hline Total $\mathrm{NO}_{2}$ as $\mathrm{N}$ & 24 & 9 & $<0.06$ & 0.002 & \pm 0.003 \\
\hline Total phosphorus as $\mathrm{P}$ & 94 & 84 & $<0.6$ & 0.01 & \pm 0.02 \\
\hline Dissolved phosphorus as $\mathrm{P}$ & 78 & 47 & $<0.5$ & 0.01 & \pm 0.02 \\
\hline Dissolved $\mathrm{PO}_{4}$ as $\mathrm{P}$ & 91 & 53 & $\leq 0.5$ & 0.004 & \pm 0.006 \\
\hline Total $\mathrm{PO}_{4}$ as $\mathrm{P}$ & 25 & 15 & $<0.5$ & 0.01 & \pm 0.02 \\
\hline \multirow[t]{2}{*}{ Total organic carbon ${ }^{\mathrm{a}}$} & 80 & 80 & $\leq 9.0$ & 0.30 & \pm 0.49 \\
\hline & 13 & 13 & 9.0 to 20 & $26 \%$ & $\pm 43 . \%$ \\
\hline \multirow[t]{2}{*}{ Color } & 59 & 59 & $\leq 60$ & 3.6 & \pm 5.9 \\
\hline & 34 & 34 & $>60,<150$ & 11.6 & \pm 19.1 \\
\hline Residue on evaporation & 92 & 92 & $<300$ & 6.6 & \pm 10.8 \\
\hline \multirow[t]{2}{*}{ Chlorophyll $a^{\mathrm{a}}, \mu \mathrm{g} / \mathrm{L}$} & 14 & 14 & $\leq 10$ & 1.1 & \pm 1.8 \\
\hline & 6 & 6 & 10 to 40 & $14.2 \%$ & $\pm 23.3 \%$ \\
\hline \multirow[t]{2}{*}{ Chlorophyll $b^{\mathrm{a}}, \mu \mathrm{g} / \mathrm{L}$} & 13 & 11 & $\leq 0.3$ & 0.07 & 0.12 \\
\hline & 7 & 7 & $>0.3,<2.1$ & $8.1 \%$ & $\pm 13.3 \%$ \\
\hline
\end{tabular}

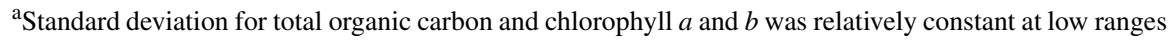
but increased with increasing concentrations at high ranges; thus, variability is expressed as a relative concentration in percent $(\%)$ for the high ranges. 


\section{Triangle Area Water Supply Monitoring Project, October 1988-September 2001, North Carolina}

Control charts are presented to assess the accuracy (variability) and bias of individual constituent analyses during the period of the project (for example, fig. 11). Changes in symbol color on control charts indicate a change in the method of analysis for a particular constituent. A cross reference for method codes (single alpha characters) is provided in table 7. The solid lines at positive and negative standard deviations of 2 indicate the analytical results that meet the laboratory qualitycontrol criterion. The distribution of the constituent concentration of blind-sample submissions also is shown (fig. 11).

The performance of methods for total and dissolved organic nitrogen plus ammonia, ammonia, and nitrite plus nitrate (fig. 11) are shown in scatterplots. Analyses for total and dissolved organic nitrogen plus ammonia were somewhat variable and positively biased in the early 1990's; however, the number of analyses more than two standard deviations from the MPV were small. The number of analyses outside of two
A.



B.
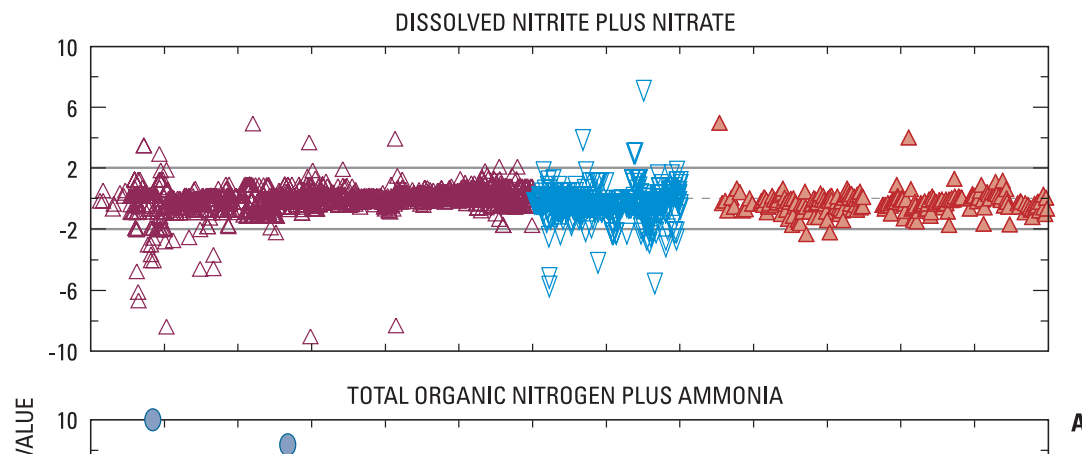

A.

- Outlier

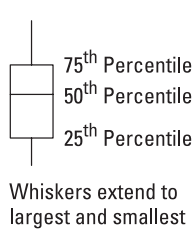

largest and smallest

point within 1.5 times

the interquartile range

B.

METHOD CODES

(identified in table 7)

O A

$\triangle B$

$\square \mathrm{C}$

$\triangle D$

$\nabla \mathrm{E}$

O F

$\triangle \mathrm{G}$

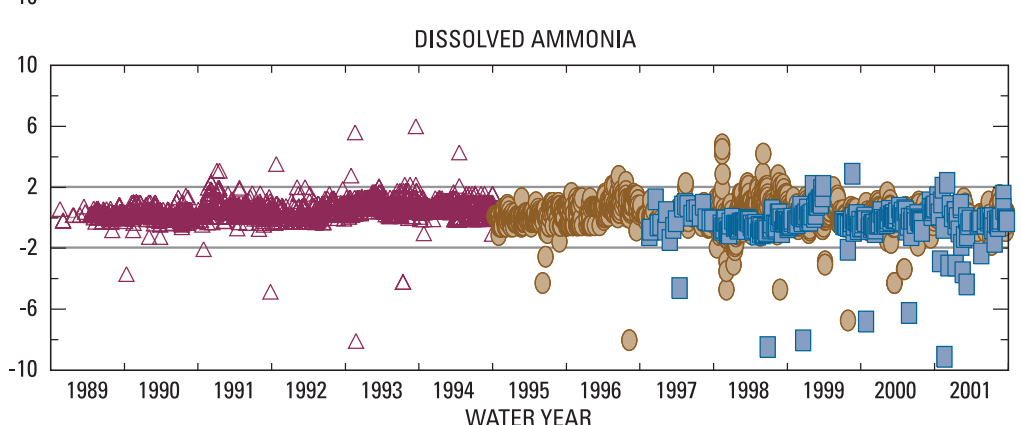

Figure 11. National Water Quality Laboratory control charts from the U.S. Geological Survey Inorganic Blind Sample Project showing (A) the distribution of double-blind sample concentrations and $(B)$ trends in deviations from double-blind sample concentrations of dissolved nitrite plus nitrate, total and dissolved organic nitrogen plus ammonia, and dissolved ammonia for water years 1989-2001. 
standard deviations from the MPV was greater for ammonia, which was variable throughout the study. Nitrite data (not shown) are available only through 1991 . Nitrite plus nitrate analyses were variable in the first 2 years of study and improved until a method change in 1995. Another method change in 1997 brought improved precision.

Total and dissolved phosphorus were most variable in the first 3 years of the study (fig. 12). A method change in 1992 increased the precision of analyses. Dissolved orthophosphate analyses also were most variable in the first 3 years and improved thereafter with the exception of several significant outliers after 1995.

Analyses of silica, fluoride, sulfate, and chloride (fig. 13); and sodium, magnesium, and calcium (fig. 14) were unbiased with low variability over the period of study. Variability of fluoride, sulfate, and chloride increased during 1990 through 1992 when a new analytical method was used. Analyses of potassium also were unbiased over the period of study but had greater variability (fig. 14).
Control charts and distributions of blind samples for metals and trace elements are shown in figures 15, 16, and 17. Most are unbiased and many have very low variability over the period of study (for example, cobalt, chromium, cadmium (fig. 15), nickel, molybdenum, lead (fig. 16), selenium, and silver (fig. 17)). Analyses of iron were highly variable and biased high for the first half of the study (fig. 16). Likewise, manganese analyses, although not as variable, were biased high prior to the 1993 water year. Zinc analyses were biased somewhat high between water years 1989 and 1994 (fig. 17). Analyses are unbiased thereafter and are very stable with the method change that occurred in 1999 (table 7). Likewise, aluminum, iron, and manganese analyses were variable during the first 5 years of study and have become markedly more stable since a method change in 1999. Mercury, which was somewhat biased from about 1996 to 1999, has been more stable since 1999.

The Organic Blind Sample Project (OBSP) of the USGS Branch of Quality Systems provides independent, external
A.

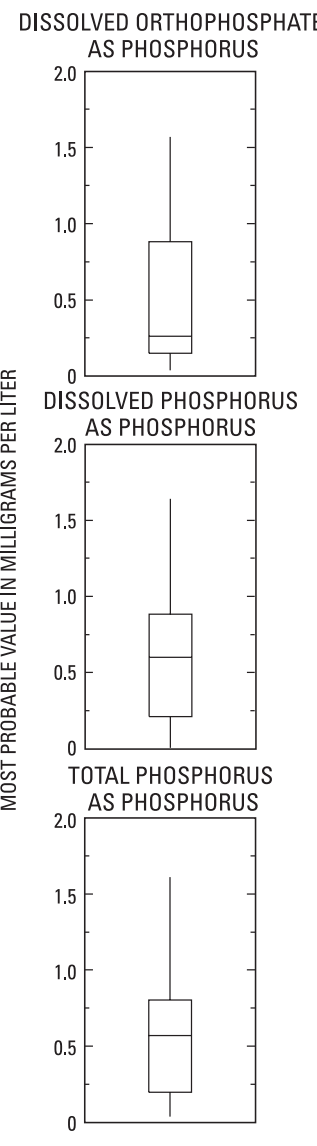

B.

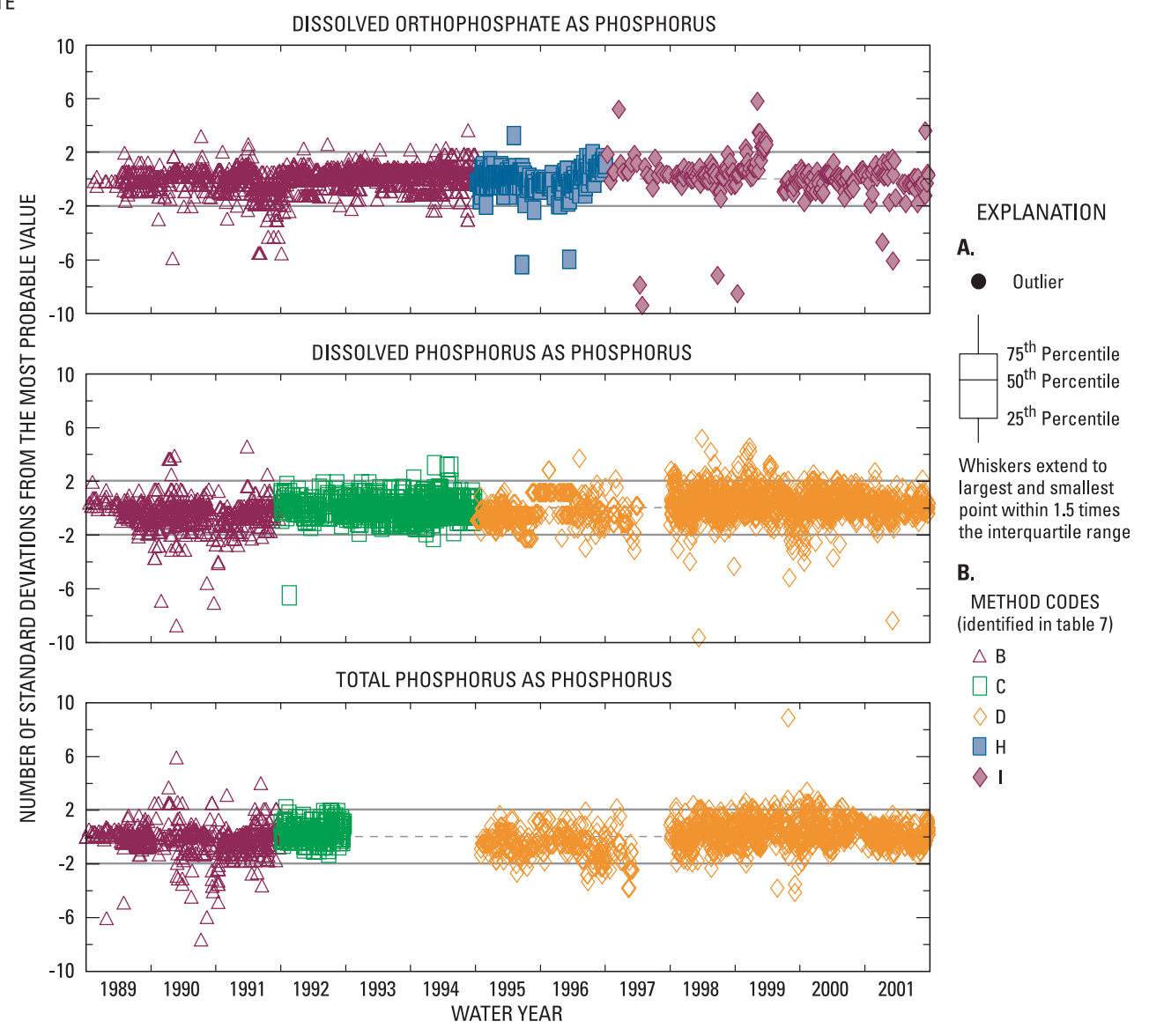

Figure 12. National Water Quality Laboratory control charts from the U.S. Geological Survey Inorganic Blind Sample Project showing (A) the distribution of double-blind sample concentrations and (B) trends in deviations from double-blind sample concentrations of dissolved orthophosphate and total and dissolved phosphorus for water years 1989-2001. 
A.
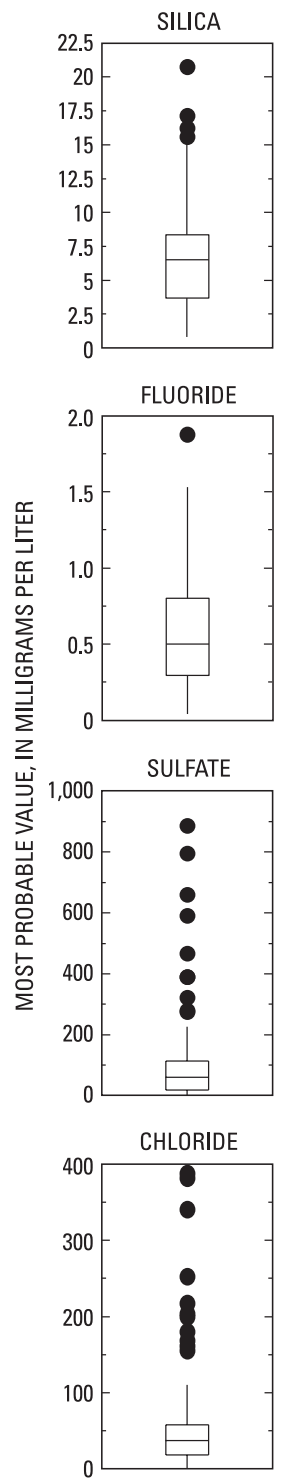

B.
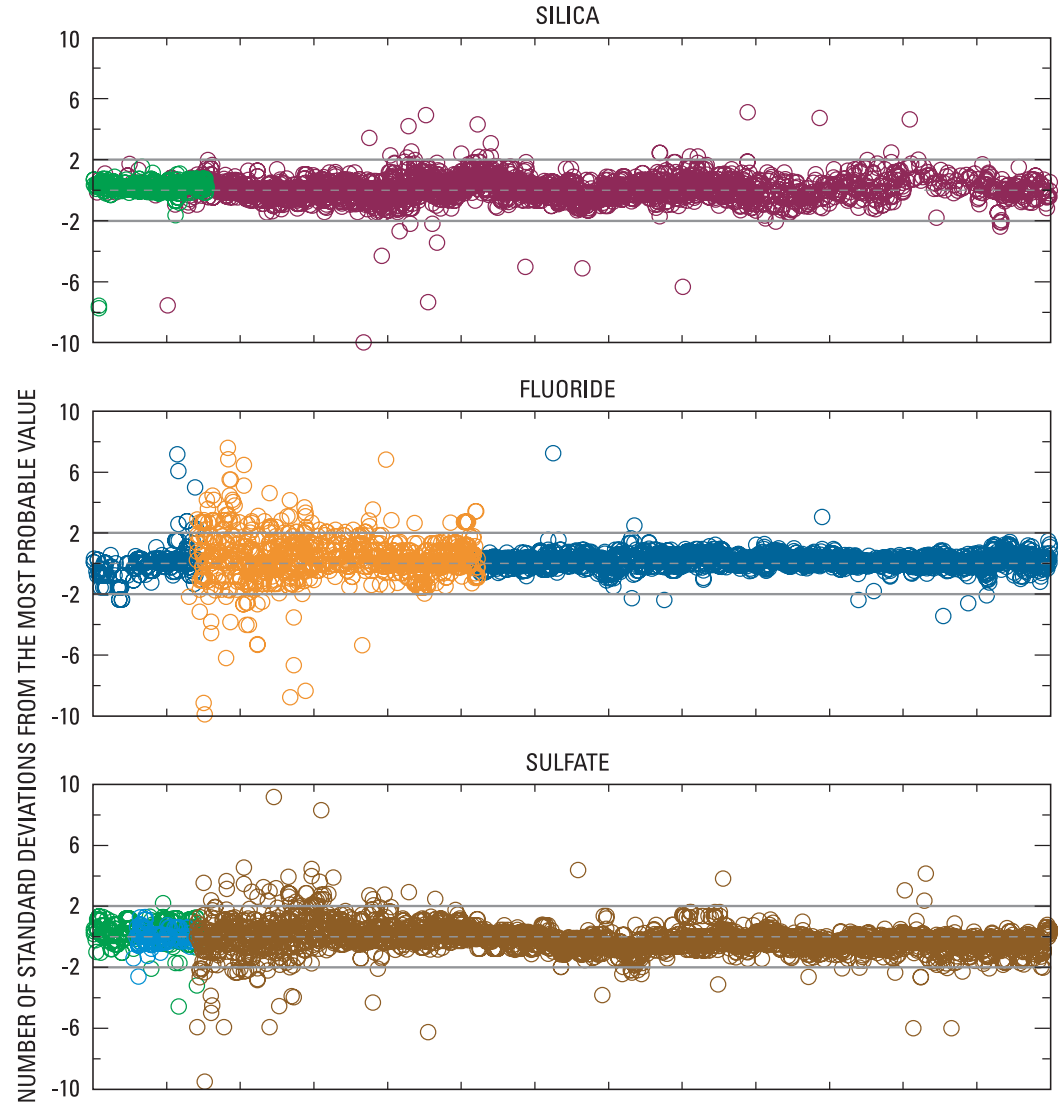

CHLORIDE



EXPLANATION

A.

- Outlier

$75^{\text {th }}$ Percentile $50^{\text {th }}$ Percentile Whiskers extend to largest and smallest point within 1.5 times the interquartile range

B.

METHOD CODES (identified in table 7)

$\mathrm{OB}$

$O C$

$O D$

$O E$

$O \mathrm{~F}$

$O G$

O J

Figure 13. National Water Quality Laboratory control charts from the U.S. Geological Survey Inorganic Blind Sample Project showing (A) the distribution of double-blind sample concentrations and (B) trends in deviations from double-blind sample concentrations of silica, fluoride, sulfate, and chloride for water years 1989-2001. 
A.
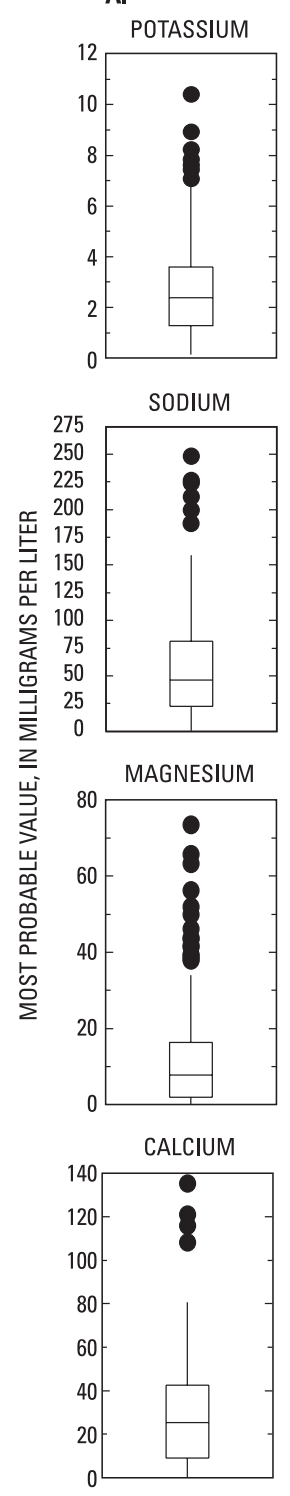

B.
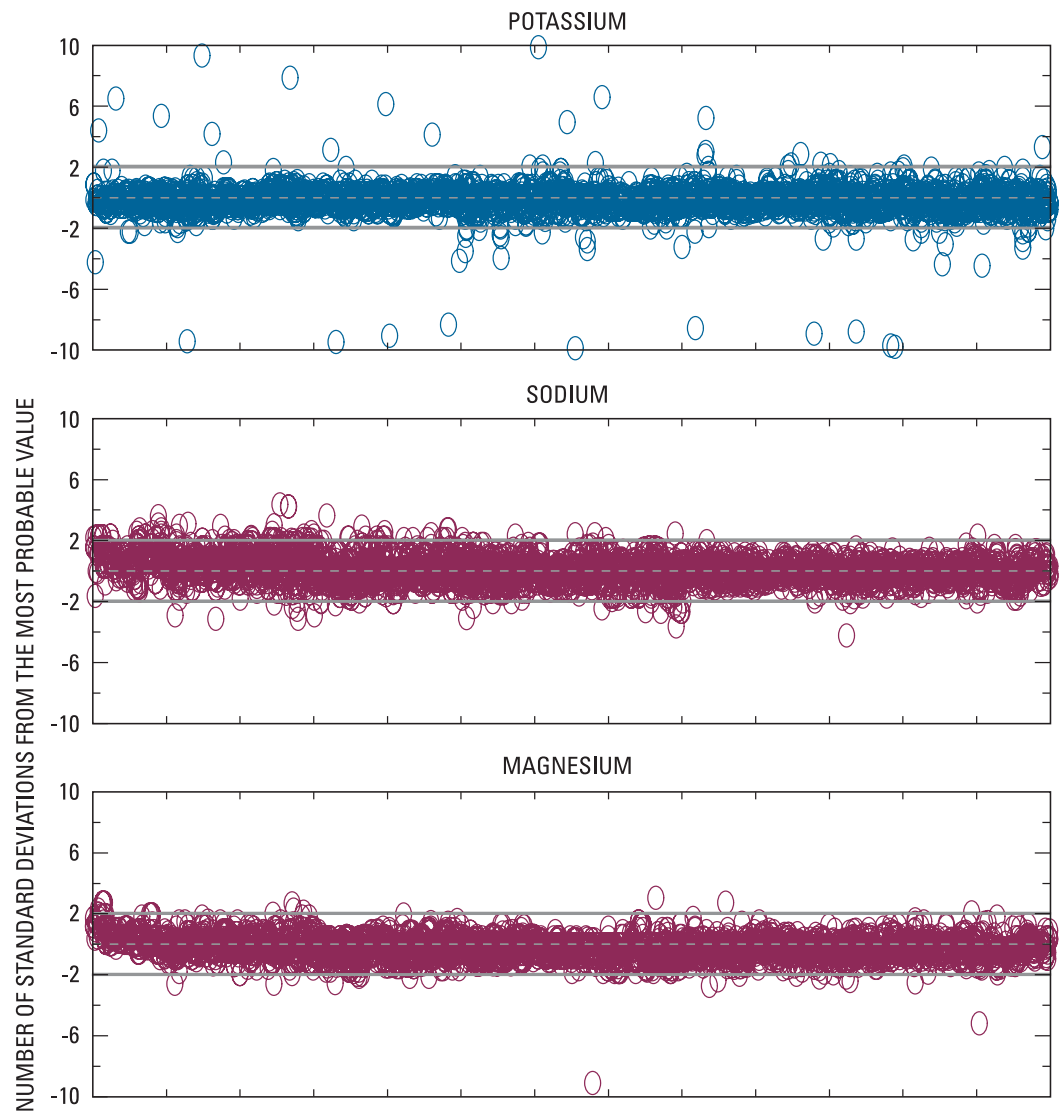
the interquartile range
Whiskers extend to largest and smallest point within 1.5 times

B.

METHOD CODES (identified in table 7) $\mathrm{OB}$

$\mathrm{OC}$

OD

EXPLANATION

- Outlier

$75^{\text {th }}$ Percentile $50^{\text {th }}$ Percentile $25^{\text {th }}$ Percentile

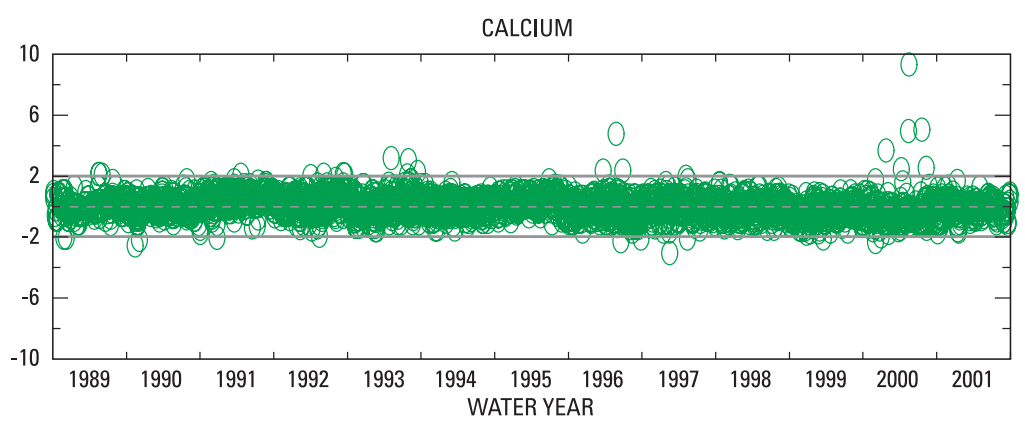

Figure 14. National Water Quality Laboratory control charts from the U.S. Geological Survey Inorganic Blind Sample Project showing (A) the distribution of double-blind sample concentrations and (B) trends in deviations from double-blind sample concentrations of potassium, sodium, magnesium, and calcium for water years 1989-2001. 
A.

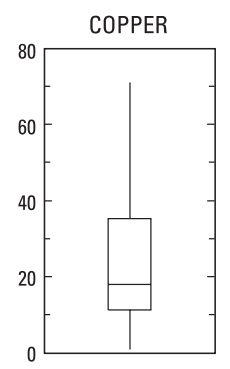

COBALT

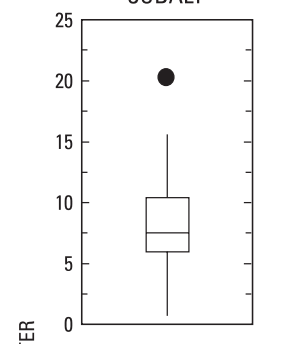

岁

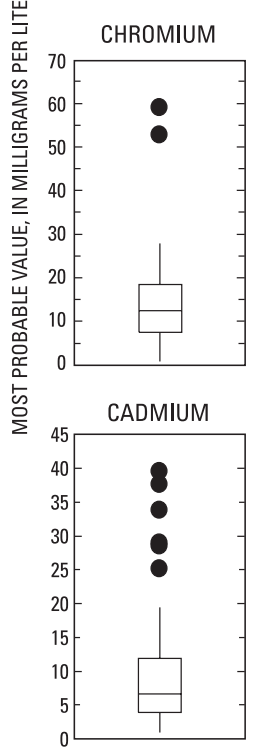

ARSENIC

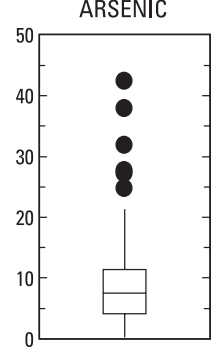

B.
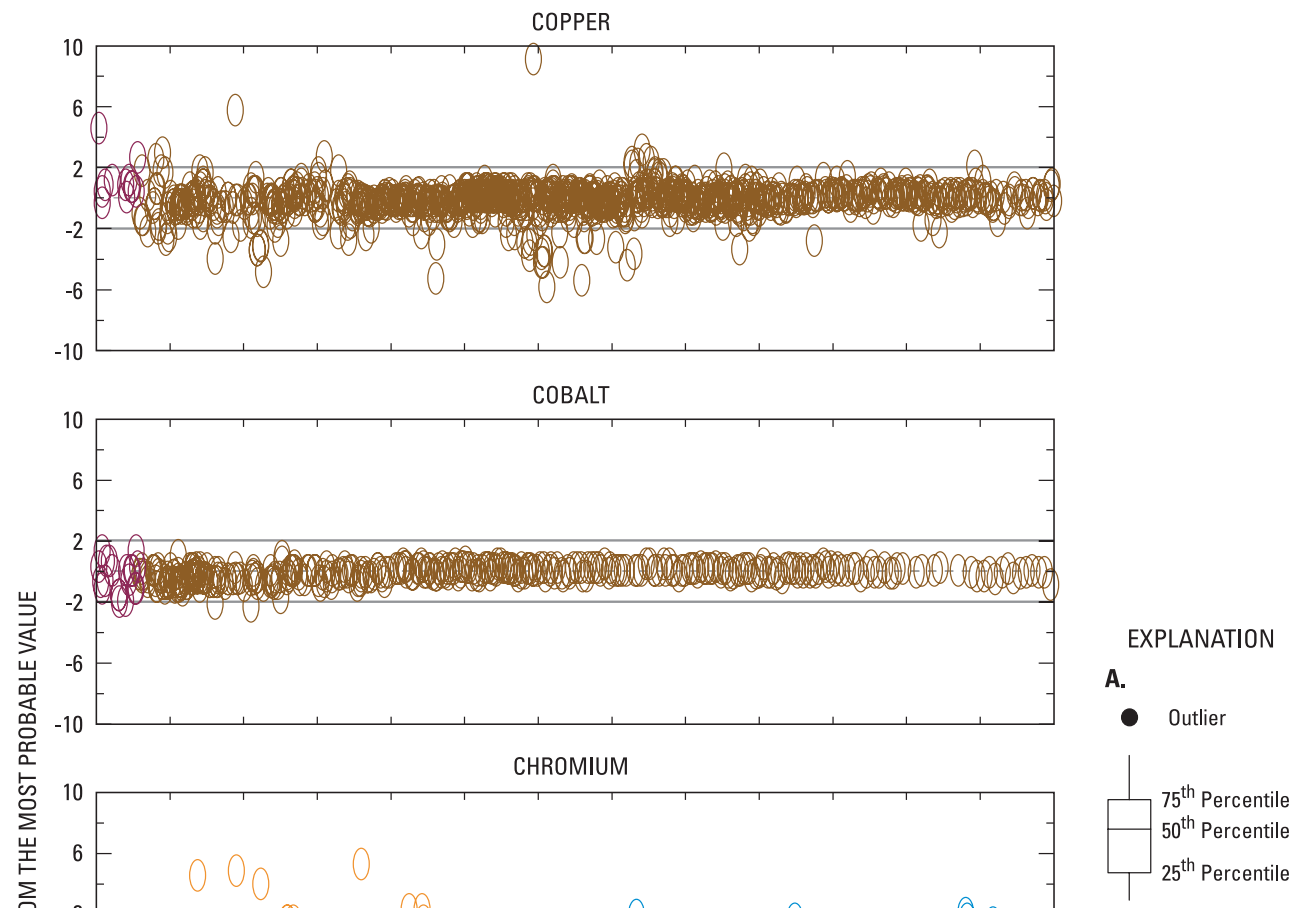

Whiskers extend to largest and smallest point within 1.5 times
the interquartile range

B.

METHOD CODES (identified in table 7)

O B

OD

O E

$\mathrm{OF}$

Figure 15. National Water Quality Laboratory control charts from the U.S. Geological Survey Inorganic Blind Sample Project showing (A) the distribution of double-blind sample concentrations and (B) trends in deviations from double-blind sample concentrations of copper, cobalt, chromium, cadmium, and arsenic for water years 1989-2001. 
A.
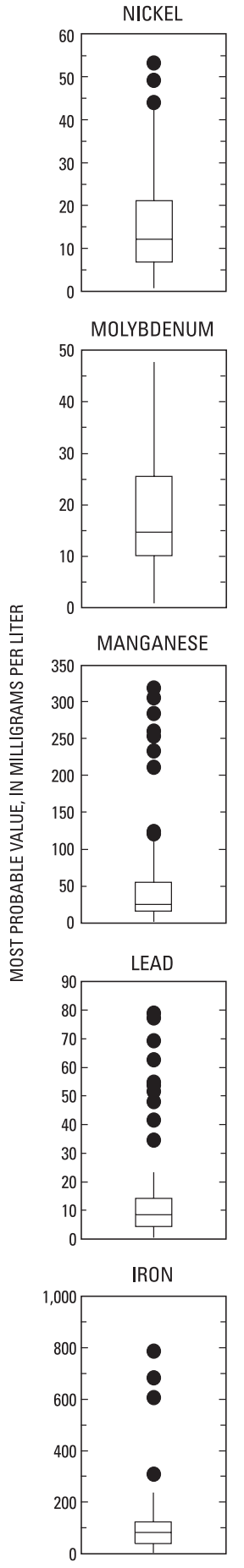

B.
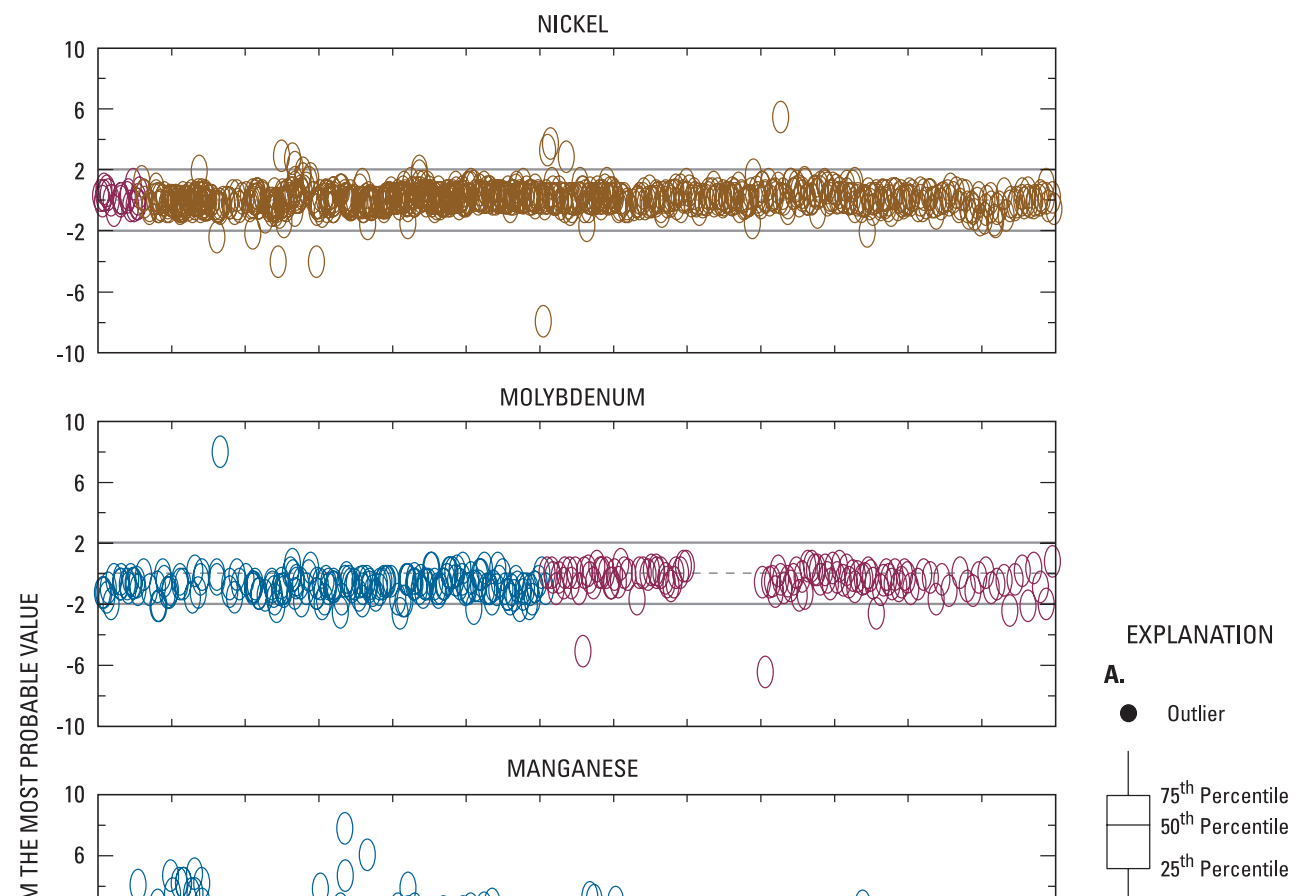

Whiskers extend to largest and smallest point within 1.5 times the interquartile range

B.

METHOD CODES (identified in table 7)

O A

O B

$\mathrm{OC}$

OD

O F

Figure 16. National Water Quality Laboratory control charts from the U.S. Geological Survey Inorganic Blind Sample Project showing (A) the distribution of double-blind sample concentrations and (B) trends in deviations from double-blind sample concentrations of nickel, molybdenum, manganese, lead, and iron for water years 1989-2001. 
A.
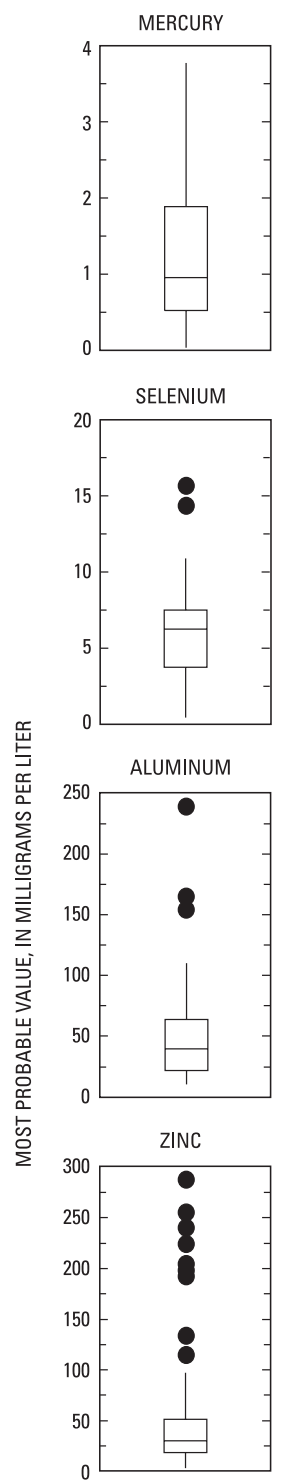

SILVER

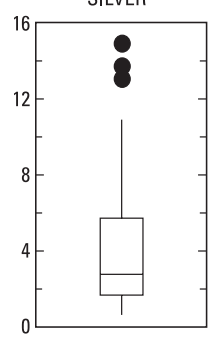

B.
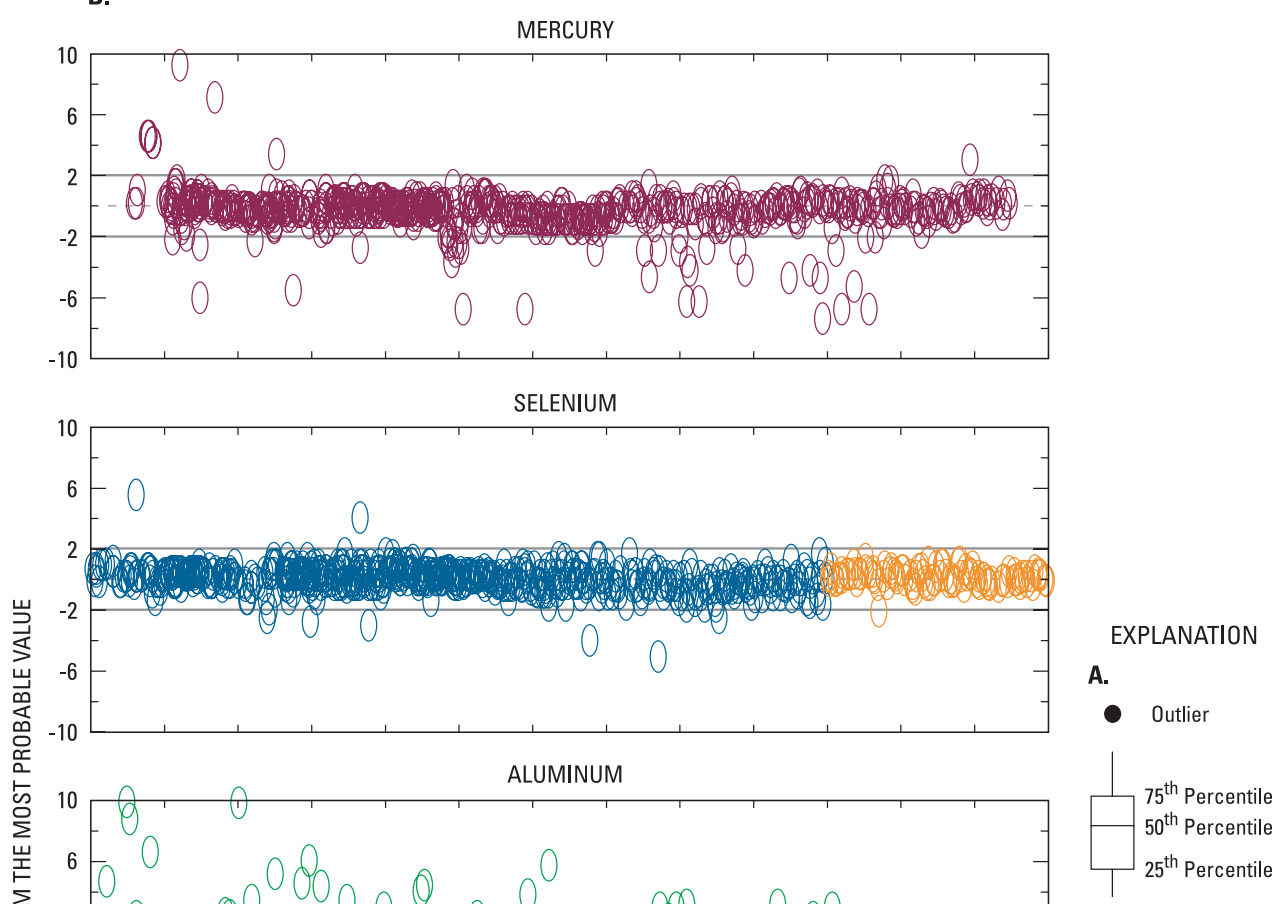

Whiskers extend to largest and smallest point within 1.5 times the interquartile range

B.

METHOD CODES (identified in table 7)

$O A$

OB

Oc

OD

OF

Figure 17. National Water Quality Laboratory control charts from the U.S. Geological Survey Inorganic Blind Sample Project showing (A) the distribution of double-blind sample concentrations and (B) trends in deviations from double-blind sample concentrations of mercury, selenium, aluminum, zinc, and silver for water years 1989-2001. 
quality assurance for organic analyses performed at the NWQL. The OBSP produces double-blind samples of known composition that are submitted to the laboratory. Spike mixtures used to produce the quality-control samples are purchased from qualified manufacturers. As of this publication date, limited OBSP quality-control data are available online at http://btdqs.usgs.gov/OBSP/index.html and, beginning in January 1996, can be used to assess laboratory bias and variability. The USGS Branch of Quality Systems compiles the data and provides reports on data quality (trends in bias, variability, and errors) to the NWQL on a quarterly basis so that corrective actions can be taken.

\section{Data Review}

The NWQL Quality Assurance Section (QAS) has responsibility for final review of analyses before they are reported to the user. Chemical logic checks, such as anioncation balance, specific conductance-anion ratio, specific conductance-cation ratio, dissolved solids-specific conductance ratio, field and laboratory measurement agreement for $\mathrm{pH}$, alkalinity, and specific conductance, and filtered components compared with raw components of constituents, are automatically processed by computer. Analytical results that do not meet acceptance criteria are reviewed by chemists in the QAS, and samples either are reanalyzed or results are approved.

\section{Performance-Evaluation Studies}

The NWQL participates in national and international interlaboratory performance-evaluation studies and has performed very well (Pirkey and Glodt, 1998). These performance-evaluation studies are as follows:

- U.S. Environmental Protection Agency water pollution, water supply, and safe drinking water act studies;

- USGS Branch of Quality Systems evaluation program for standard reference samples;

- National Water Research Institute of Canada; and

- National Oceanic and Atmospheric Administration intercomparison program for marine sediment and tissue.

\section{Summary}

The Triangle Area Water Supply Monitoring Project was initiated in October 1988 to provide long-term water-quality data for six area water-supply reservoirs and their tributaries. Additional objectives of the project are to provide data that can be used to determine the effectiveness of large-scale changes in water-resource management practices, document differences in water quality among water-supply types (large multiuse reservoir, small reservoir, run of river), and provide tributaryloading and in-lake data for water-quality modeling of Falls and Jordan Lakes. By September 2001, the project had progressed in four phases and included as many as 34 sites. Most sites were sampled and analyzed by the USGS. Some sites were already part of the North Carolina DWQ statewide ambient waterquality network and continued to be sampled for that network. The DWQ sites were sampled by the USGS only occasionally during high-flow events to supplement data collected by the DWQ. The network has provided data on streamflow, physical properties, and concentrations of nutrients, major ions, metals, trace elements, chlorophyll $a$ and $b$, total organic carbon, suspended sediment, and selected synthetic organic compounds.

Each study phase had a special area of focus for which extra targeted sampling was done. In phase I, the special focus was on the occurrence of synthetic organic compounds in streambed sediments in the Haw River basin. In phase II the special focus was to identify whether pesticides detected in phase I in streamwater downstream from wastewater discharges originated from the wastewater effluents, from upstream sources, or both. In phase III, the special focus was on the presence of Cryptosporidium parvum oocysts and Giardia Lamblia cysts in raw-water supplies. In phase IV, the special focus was on the collection of more samples during high-flow events.

Records of water quality collected by the USGS were stored in the NWIS database. Environmental water-quality data can be retrieved from the USGS Website http:// waterdata.usgs.gov/nwis/and also are included in the appendix of this report. Quality-control data can be obtained by contacting the USGS North Carolina District office in Raleigh. Methods of sample collection follow standard published and unpublished USGS protocols. A significant change in datacollection methods occurred in 1992 when the parts-per-billion protocol became the standard protocol for the USGS. These protocols are detailed in the USGS National Field Manual.

Some laboratory methods and reporting levels changed during the study. A method reference for each constituent is stored in NWIS with the water-quality record. Reporting levels for each constituent and method are reported herein.

Instantaneous streamflow at the time of sample collection was obtained from records of continuous gage height at streamgaging stations in the network. Streamflow records were stored in the NWIS database and can be retrieved from the USGS North Carolina District office in Raleigh. A goal of the project was to measure water quality during a range of streamflow conditions. A comparison of long-term streamflow durations to sampled streamflow durations indicates that this goal was achieved, and samples were collected over a wide range of streamflow conditions, including during many highflow events.

Project quality-assurance activities include written procedures for sample collection, record management and archive, collection of field quality-control samples (blank 
samples and replicate samples), and monitoring of the quality of field supplies. In addition to project quality-assurance activities, the quality of laboratory analyses was assessed through laboratory quality-assurance practices and an independent laboratory quality-control assessment provided by the USGS Branch of Quality Systems through the Inorganic Blind Sample Project (IBSP) and the Organic Blind Sample Project (OBSP).

\section{Selected References}

American Public Health Association, American Water Works Association, Water Environment Federation, 1992, Standard methods for the examination of water and wastewater $\left(18^{\text {th }}\right.$ ed.): Washington, D.C., American Public Health Association [variously paged].

Barker, R.G., George, E.D., Rinehardt, J.F., and Eddins, W.H., 1994, Water-resources data, North Carolina, water year 1993: U.S. Geological Survey Water-Data Report NC-93-1, 590 p.

Barker, R.G., Ragland, B.C., Rinehardt, J.F., and Eddins, W.H., 1992, Water-resources data, North Carolina, water year 1991: U.S. Geological Survey Water-Data Report NC-91-1, 349 p.

Britton, L.J., and Greeson, P.E., eds., 1989, Methods for collection and analysis of aquatic biological and microbiological samples: U.S. Geological Survey Techniques of Water-Resources Investigations, book 5, chap. A4, 363 p.

Childress, C.J.O., and Bathala, Neeti, 1997, Water-quality trends for streams and reservoirs in the Research Triangle Area of North Carolina, 1983-95: U.S. Geological Survey Water-Resources Investigations Report 97-4061, 18 p.

Childress, C.J.O., and Treece, M.W., Jr., 1996, Water and bedmaterial quality of selected streams and reservoirs in the Research Triangle Area of North Carolina, 1988-94: U.S. Geological Survey Water-Resources Investigations Report 95-4282, 79 p.

Connor, B.F., Rose, D.L., Noriega, M.C., Murtagh, Lucinda, and Abney, S.R., 1997, Methods of analysis by the U.S. Geological Survey National Water Quality Laboratory-Determination of 86 volatile organic compounds in water by gas chromatography/mass spectrometry, including detections less than reporting limits: U.S. Geological Survey Open-File Report 97-829, 78 p.

Edwards, T.K., and Glysson, G.D., 1999, Field methods for measurement of fluvial sediment: U.S. Geological Survey Techniques of Water-Resources Investigations, book 3, chap. C2, $80 \mathrm{p}$.

Faires, L.M., 1993, Methods of analysis by the U.S. Geological Survey National Water Quality Laboratory-Determination of metals in water by inductively coupled plasma-mass spectrometry: U.S. Geological Survey Open-File Report 92-634, 28 p.
Fishman, M.J., ed., 1993, Methods of analysis by the U.S. Geological Survey National Water Quality LaboratoryDetermination of inorganic and organic constituents in water and fluvial sediments: U.S. Geological Survey Open-File Report 93-125, 217 p.

Fishman, M.J., and Friedman, L.C., eds., 1989, Methods for determination of inorganic substances in water and fluvial sediments: U.S. Geological Survey Techniques of Water-Resources Investigations, book 5, chap. A1, $545 \mathrm{p}$.

Fishman, M.J., Raese, J.W., Gerlitz, C.N., and Husband, R.A., 1994, U.S. Geological Survey approved inorganic and organic methods for the analysis of water and fluvial sediment, 1954-94: U.S. Geological Survey Open-File Report 94-351, 55 p.

Friedman, L.C., and Erdmann, D.E., eds., 1982, Qualityassurance practices for the chemical and biological analyses of water and fluvial sediments: U.S. Geological Survey Techniques of Water-Resources Investigations, book 5, chap. A6, 181 p.

Garbarino, J.R., and Damrau, D.L., 2001, Methods of analysis by the U.S. Geological Survey National Water Quality Laboratory-Determination of organic plus inorganic mercury in filtered and unfiltered natural water with cold vapor-automatic fluorescence spectrometry: U.S. Geological Survey Water-Resources Investigations Report 01-4132, $16 \mathrm{p}$.

Garbarino, J.R., and Struzeski, T.M., 1998, Methods of analysis by the U.S. Geological Survey National Water Quality Laboratory-Determination of elements in whole-water digests using inductively coupled plasma-optical emission spectrometry and inductively coupled plasma-mass spectrometry: U.S. Geological Survey Open-File Report 98-165, $101 \mathrm{p}$.

Garrett, R.G., Taylor, J.E., and Middleton, T.L., 1994, Waterquality data for selected North Carolina streams and reservoirs in the Triangle Area Water Supply Monitoring Project, 1988-92: U.S. Geological Survey Open-File Report 94-379, $255 \mathrm{p}$.

Gilbert, R.O., 1987, Statistical methods for environmental pollution monitoring: New York, Van Nostrand Reinhold Co., Inc., 320 p.

Gunter, H.C., Rinehardt, J.F., Eddins, W.H., and Barker, R.G., 1993, Water-resources data, North Carolina, water year 1992: U.S. Geological Survey Water-Data Report NC-92-1, $370 \mathrm{p}$.

Guy, H.P., 1969, Laboratory theory and methods for sediment analysis: U.S. Geological Survey Techniques of Water-Resources Investigations, book 5, chap. C1, $58 \mathrm{p}$.

Guy, H.P., and Norman, V.W., 1970, Field methods of measurement of fluvial sediment: U.S. Geological Survey Techniques of Water-Resources Investigations, book 3, chap. C2, 59 p. 
Hoffman, G.L., Fishman, M.J., and Garbarino, J.R., 1996, Methods of analysis by the U.S. Geological Survey National Water Quality Laboratory-In-bottle acid digestion of whole-water samples: U.S. Geological Survey Open-File Report 96-225, 28 p.

Jones, S.R., and Garbarino, J.R., 1999, Methods of analysis by the U.S. Geological Survey National Water Quality Laboratory-Determination of arsenic and selenium in water and sediment by graphite furnace-atomic absorption spectrophotometry: U.S. Geological Survey Open-File Report 98-639, $39 \mathrm{p}$.

Jones, S.R., and McLain, B.J., 1997, Methods of analysis by the U.S. Geological Survey National Water Quality Laboratory-Determination of molybdenum in water by graphite furnace atomic absorption spectrophotometry: U.S. Geological Survey Open-File Report 97-198, 25 p.

Lane S.L., and Fay R.G., 1997, Safety in field activities: U.S. Geological Survey Techniques of Water-Resources Investigations, book 9, chap. A9 [variously paged].

McLain, B.J., 1993, Methods of analysis by the U.S. Geological Survey National Water Quality Laboratory-Determination of chromium in water by graphite furnace atomic absorption spectrophotometry: U.S. Geological Survey Open-File Report 93-449, 16 p.

Myers, D.N., and Wilde, F.D., eds., 1997, Biological indicators: U.S. Geological Survey Techniques of Water-Resources Investigations, book 9, chap. A7 [variously paged].

North Carolina State Data Center, 2002a, Census information, accessed in April 2002 at http://census.state.nc.us/.

North Carolina State Data Center, 2002b, State demographics, accessed in April 2002 at http://demog.state.nc.us/.

Office of Water Data Coordination, 1977, National handbook of recommended methods for water-data acquisition: Reston, Va., U.S. Department of the Interior [variously paged].

Orange Water and Sewer Authority, 2001, Capstone reportComprehensive water and sewer master plan: Carrboro, N.C., Orange Water and Sewer Authority, 49 p.

Patton, C.J., and Truitt, E.P., 1992, Methods of analysis by the U.S. Geological Survey National Water Quality

Laboratory-Determination of total phosphorus by a Kjeldahl digestion method and an automated colorimetric finish that includes dialysis: U.S. Geological Survey OpenFile Report 92-146, 39 p.

Patton, C.J., and Truitt, E.P., 2000, Methods of analysis by the U.S. Geological Survey National Water Quality Laboratory-Determination of ammonium plus organic nitrogen by a Kjeldahl digestion method and an automated photometric finish that includes digest cleanup by gas diffusion: U.S. Geological Survey Open-File Report 00-170, $31 \mathrm{p}$.

Pirkey, K.D., and Glodt, S.R., 1998, Quality control at the U.S. Geological Survey National Water Quality Laboratory: U.S. Geological Survey Fact Sheet FS-026-98, 4 p.

Pritt, J.W., and Raese, J.W., eds., 1992, Quality assurance/ quality control manual-National Water Quality Laboratory: U.S. Geological Survey Open-File Report 92-495, 33 p.
Radtke, D.B., 1997, Bottom-material samples: U.S. Geological Survey Techniques of Water-Resources Investigations, book 9, chap. A8 [variously paged].

Ragland, B.C., Barker, R.G., Eddins, W.H., Padyk, A.J., and Rinehardt, J.F., 1990, Water-resources data, North Carolina, water year 1989: U.S. Geological Survey Water-Data Report $\mathrm{NC}-89-1,434 \mathrm{p}$.

Ragland, B.C., Barker, R.G., Eddins, W.H., and Rinehardt, J.F., 1991, Water-resources data, North Carolina, water year 1990: U.S. Geological Survey Water-Data Report NC-90-1, $389 \mathrm{p}$.

Ragland, B.C., Barker, R.G., and Robinson, J.B., 2000, Waterresources data, North Carolina, water year 1999: U.S. Geological Survey Water-Data Report NC-99-1B, $514 \mathrm{p}$.

Ragland, B.C., Barker, R.G., and Robinson, J.B., 2001, Waterresources data, North Carolina, water year 2000: U.S. Geological Survey Water-Data Report NC-00-1B, $602 \mathrm{p}$.

Ragland, B.C., Barker, R.G., and Robinson, J.B., 2002, Waterresources data, North Carolina, water year 2001: U.S. Geological Survey Water-Data Report NC-01-1B, $657 \mathrm{p}$.

Ragland, B.C., Barker, R.G., and Robinson, J.B., 2003, Waterresources data, North Carolina, water year 2002: U.S. Geological Survey Water-Data Report NC-02-1B, $645 \mathrm{p}$.

Ragland, B.C., Smith, D.G., Barker, R.G., and Rinehardt, J.F., 1995, Water-resources data, North Carolina, water year 1994: U.S. Geological Survey Water-Data Report NC-94-1, $578 \mathrm{p}$.

Ragland, B.C., Smith, D.G., Barker, R.G., and Rinehardt, J.F., 1996, Water-resources data, North Carolina, water year 1995: U.S. Geological Survey Water-Data Report NC-95-1, $618 \mathrm{p}$.

Ragland, B.C., Smith, D.G., Barker, R.G., Rinehardt, J.F., and Robinson, J.B., 1997, Water-resources data, North Carolina, water year 1996: U.S. Geological Survey Water-Data Report NC-96-1, $514 \mathrm{p}$.

Ragland, B.C., Smith, D.G., Barker, R.G., and Robinson, J.B., 1998, Water-resources data, North Carolina, water year 1997: U.S. Geological Survey Water-Data Report NC-97-1, $544 \mathrm{p}$.

Ragland, B.C., Smith, D.G., Barker, R.G., and Robinson, J.B., 1999, Water-resources data, North Carolina, water year 1998: U.S. Geological Survey Water-Data Report NC-98-1, $690 \mathrm{p}$.

Ragland, B.C., Walters, D.G., Cartano, G.D., and Taylor, J.E., 2000, Water-resources data, North Carolina, water year 1999: U.S. Geological Survey Water-Data Report NC-99$1 \mathrm{~A}, 558 \mathrm{p}$.

Ragland, B.C., Walters, D.G., Cartano, G.D., and Taylor, J.E., 2001, Water-resources data, North Carolina, water year 2000: U.S. Geological Survey Water-Data Report NC-00$1 \mathrm{~A}, 591 \mathrm{p}$. 
Ragland, B.C., Walters, D.G., Cartano, G.D., and Taylor, J.E., 2002, Water-resources data, North Carolina, water year 2001: U.S. Geological Survey Water-Data Report NC-01$1 \mathrm{~A}, 615 \mathrm{p}$.

Ragland, B.C., Walters, D.G., Cartano, G.D., and Taylor, J.E., 2003, Water-resources data, North Carolina, water year 2002: U.S. Geological Survey Water-Data Report NC-02$1 \mathrm{~A}, 534 \mathrm{p}$.

Rantz, S.E., and others, 1983, Measurement and computation of streamflow: U.S. Geological Survey Water-Supply Paper 2175, v. 1, 284 p.; v. 2, 631 p.

Rose, D.L., and Schroeder, M.P., 1995, Methods of analysis by the U.S. Geological Survey National Water Quality Laboratory-Determination of volatile organic compounds in water by purge and trap capillary gas chromatography/ mass spectrometry: U.S. Geological Survey Open-File Report 94-708, 26 p.

Sandstrom, M.W., Wydoski, D.S., Schroeder, M.P., Zamboni, J.L., and Foreman, W.T., 1992, Methods of analysis by the U.S. Geological Survey National Water Quality Laboratory-Determination of organonitrogen herbicides in water by solid-phase extraction and capillary-column gas chromatography/mass spectrometry with selected-ion monitoring: U.S. Geological Survey Open-File Report 91-519, 26 p.

Town of Cary, 2002, Water treatment, accessed in November 2003 at http://www.townofcary.org/depts/pwdept/ watertreatment.htm.

U.S. Geological Survey, 1994, New preservation techniques for nutrient samples: Office of Water Quality Technical Memorandum 94.16 [released August 5, 1994], 11 p., accessed in November 2003 at http://water.usgs.gov/admin/ memo/QW/qw94.16.html.

U.S. Geological Survey, 1997, USGS Inorganic Blind Sample Project monitoring and evaluating laboratory analytical quality: U.S. Geological Survey Fact Sheet FS-136-97, accessed in April 2003 at http://btdqs.usgs.gov/bsp/ mainpage.html.

U.S. Geological Survey, 1997-present, National field manual for the collection of water-quality data: U.S. Geological Survey Techniques of Water-Resources Investigations, book 9, chaps. A1-A9, 2 v. [variously paged]. [Also available online at http://pubs.water.usgs.gov/twri9A. Chapters originally were published from 1997 to 1999; updates and revisions are ongoing and are summarized at http://water.usgs.gov/owq/FieldManual/mastererrata.html]
Werner, S.L., Burkhardt, M.R., and DeRusseau, S.N., 1996, Methods of analysis by the U.S. Geological Survey National Water Quality Laboratory-Determination of pesticides in water by Carbopak-B solid-phase extraction and highperformance liquid chromatography: U.S. Geological Survey Open-File Report 96-216, 42 p.

Wershaw, R.L., Fishman, M.J., Grabbe, R.R., and Lowe, L.E., eds., 1987, Methods for determination of organic substances in water and fluvial sediments: U.S. Geological Survey Techniques in Water-Resources Investigations, book 5, chap. A3, 80 p.

Wilde, F.D., and Radtke, D.B., eds., 1998, Field measurements: U.S. Geological Survey Techniques of Water-Resources Investigations, book 9, chap. A6 [variously paged].

Wilde, F.D., Radtke, D.B., Gibs, Jacob, and Iwatsubo, R.T., eds., 1998a, Preparations for water sampling: U.S.

Geological Survey Techniques of Water-Resources Investigations, book 9, chap. A1 [variously paged].

Wilde, F.D., Radtke, D.B., Gibs, Jacob, and Iwatsubo, R.T., eds., 1998b, Selection of equipment for water sampling: U.S. Geological Survey Techniques of Water-Resources Investigations, book 9, chap. A2 [variously paged].

Wilde, F.D., Radtke, D.B., Gibs, Jacob, and Iwatsubo, R.T., eds., 1998c, Cleaning of equipment for water sampling: U.S. Geological Survey Techniques of Water-Resources Investigations, book 9, chap. A3 [variously paged].

Wilde, F.D., Radtke, D.B., Gibs, Jacob, and Iwatsubo, R.T., eds., 1999a, Collection of water samples: U.S. Geological Survey Techniques of Water-Resources Investigations, book 9, chap. A4, 152 p.

Wilde, F.D., Radtke, D.B., Gibs, Jacob, and Iwatsubo, R.T., eds., 1999b, Processing of water samples: U.S. Geological Survey Techniques of Water-Resources Investigations, book 9, chap. A5, 128 p.

Zaugg, S.D., Sandstrom, M.W., Smith, S.G., and Fehlberg, K.M., 1995, Methods of analysis by the U.S. Geological Survey National Water Quality Laboratory-Determination of pesticides in water by $\mathrm{C}-18$ solid-phase extraction and capillary-column gas chromatography/mass spectrometry with selected-ion monitoring: U.S. Geological Survey OpenFile Report 95-181, 60 p. 
Table 7. Inorganic constituents and physical properties analyzed by the U.S. Geological Survey National Water Quality Laboratory for the Triangle Area Water Supply Monitoring Project, and the methods used for sample analyses.

[USGS, U.S. Geological Survey; ID, identification; mg/L, milligram per liter; ICP, induction-coupled argon plasma; bold numbers are lowest reporting level; ${ }^{\circ} \mathrm{C}$, degree Celsius; - , not applicable; $\mu$ S/cm, micro-

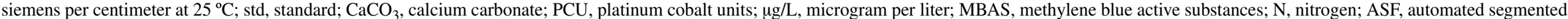
flow; P, phosphorus; OES, optical emission spectrometry; AA, atomic absorption spectrometry]

\begin{tabular}{|c|c|c|c|c|c|c|c|}
\hline Constituent & $\begin{array}{l}\text { Parameter } \\
\text { code }\end{array}$ & $\begin{array}{l}\text { Method } \\
\text { code }\end{array}$ & $\begin{array}{c}\text { Method } \\
\text { refer- } \\
\text { ence }^{\mathrm{a}}\end{array}$ & $\begin{array}{c}\text { USGS } \\
\text { method } \\
\text { ID }^{\mathrm{b}}\end{array}$ & $\begin{array}{l}\text { Period } \\
\text { of } \\
\text { record }\end{array}$ & $\begin{array}{l}\text { Reporting } \\
\text { level }\end{array}$ & Analytical method \\
\hline \multicolumn{8}{|c|}{ Major ions } \\
\hline \multirow[t]{4}{*}{ Calcium, in $\mathrm{mg} / \mathrm{L}$} & 00915 & $\mathrm{D}$ & $\mathrm{B}, \mathrm{D}$ & I-1472-87 & $10 / 88-09 / 95$ & 0.1 & Atomic emission spectrometric, ICP. \\
\hline & & & & & $10 / 95-09 / 98$ & 0.02 & \\
\hline & & & & & $10 / 98-10 / 00$ & 0.02 & \\
\hline & & & & & $10 / 00-09 / 01$ & 0.011 & \\
\hline \multirow[t]{6}{*}{ Magnesium, in mg/L } & 00925 & $\mathrm{C}$ & $\mathrm{B}, \mathrm{D}$ & $\mathrm{I}-1472-87$ & $10 / 88-09 / 95$ & 0.1 & Atomic emission spectrometric, ICP. \\
\hline & & & & & $10 / 95-12 / 97$ & 0.01 & \\
\hline & & & & & $12 / 97-09 / 98$ & 0.004 & \\
\hline & & & & & $10 / 98-09 / 99$ & 0.004 & \\
\hline & & & & & $10 / 99-10 / 00$ & 0.014 & \\
\hline & & & & & $10 / 00-09 / 01$ & 0.008 & \\
\hline \multirow[t]{5}{*}{ Sodium, in $\mathrm{mg} / \mathrm{L}$} & 00930 & $\mathrm{C}$ & $\mathrm{B}, \mathrm{D}$ & $\mathrm{I}-1472-87$ & $10 / 88-09 / 95$ & 0.1 & Atomic emission spectrometric, ICP. \\
\hline & & & & & $10 / 95-12 / 97$ & 0.2 & \\
\hline & & & & & $12 / 97-09 / 98$ & 0.1 & \\
\hline & & & & & $10 / 98-09 / 99$ & 0.06 & \\
\hline & & & & & $10 / 99-10 / 01$ & 0.09 & \\
\hline \multirow[t]{3}{*}{ Potassium, in $\mathrm{mg} / \mathrm{L}$} & 00935B & B & $\mathrm{E}$ & $\mathrm{I}-1630-85$ & $10 / 88-09 / 99$ & 0.1 & Atomic absorption spectrometry, direct. \\
\hline & & & & & $10 / 99-10 / 00$ & 0.24 & \\
\hline & & & & & $11 / 00-09 / 01$ & 0.11 & \\
\hline \multirow[t]{6}{*}{ Chloride, in $\mathrm{mg} / \mathrm{L}$} & 00940 & $\mathrm{E}$ & $\mathrm{E}$ & $\mathrm{I}-2187-78$ & $10 / 88-04 / 90$ & 0.1 & Colorimetry, automated. \\
\hline & 00940 & $\mathrm{~J}$ & B & I-2057-90 & $04 / 90-10 / 92$ & 0.1 & Ion-exchange chromatography, OMNIPAX-500. \\
\hline & 00940 & $\mathrm{E}$ & $\mathrm{E}$ & I-2057-85 & $12 / 92-01 / 94$ & 0.1 & Colorimetry, automated. \\
\hline & 00940 & $\mathrm{~J}$ & $\mathrm{E}$ & $\mathrm{I}-2057-85$ & $1 / 3 / 94-09 / 99$ & 0.1 & Ion-exchange chromatography, Dionex AS4A. \\
\hline & & & & & $10 / 99-11 / 00$ & 0.29 & \\
\hline & & & & & $11 / 00-09 / 01$ & 0.08 & \\
\hline \multirow[t]{6}{*}{ Sulfate, in $\mathrm{mg} / \mathrm{L}$} & 00945 & $\mathrm{D}$ & $\mathrm{E}$ & $\mathrm{I}-2823-85$ & $10 / 88-04 / 89$ & 0.2 & Turbidimetry, automated. \\
\hline & 00945 & $\mathrm{~F}$ & $\mathrm{E}$ & $\mathrm{I}-2823-85$ & $04 / 89-04 / 90$ & & Turbidimetry, automated (corrected). \\
\hline & 00945 & G & $\mathrm{B}$ & $\mathrm{I}-2057-90$ & $04 / 90-12 / 93$ & 0.1 & Ion-exchange chromatography, OMNIPAX-500. \\
\hline & & & $\mathrm{E}$ & $\mathrm{I}-2057-85$ & $01 / 94-09 / 99$ & 0.1 & Ion-exchange chromatography, Dionex AS4A. \\
\hline & & & & & $10 / 99-11 / 00$ & 0.31 & \\
\hline & & & & & $11 / 00-09 / 01$ & 0.11 & \\
\hline
\end{tabular}


Table 7. Inorganic constituents and physical properties analyzed by the U.S. Geological Survey National Water Quality Laboratory for the Triangle Area Water Supply Monitoring Project, and the methods used for sample analyses.-Continued



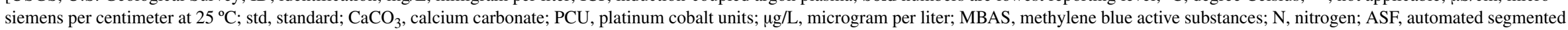
flow; P, phosphorus; OES, optical emission spectrometry; AA, atomic absorption spectrometry]

\begin{tabular}{|c|c|c|c|c|c|c|c|}
\hline Constituent & $\begin{array}{l}\text { Parameter } \\
\text { code }\end{array}$ & $\begin{array}{c}\text { Method } \\
\text { code }\end{array}$ & $\begin{array}{c}\text { Method } \\
\text { refer- } \\
\text { ence }^{a}\end{array}$ & $\begin{array}{c}\text { USGS } \\
\text { method } \\
\text { ID }\end{array}$ & $\begin{array}{l}\text { Period } \\
\text { of } \\
\text { record }\end{array}$ & $\begin{array}{l}\text { Reporting } \\
\text { level }\end{array}$ & Analytical method \\
\hline \multicolumn{8}{|c|}{ Major ions (Continued) } \\
\hline \multirow[t]{4}{*}{ Fluoride, in $\mathrm{mg} / \mathrm{L}$} & 00950 & B & $\mathrm{E}$ & $\mathrm{I}-2327-78$ & $10 / 88-04 / 90$ & 0.1 & Ion selective electrode, automated. \\
\hline & 00950 & $\mathrm{E}$ & $\mathrm{B}$ & $\mathrm{I}-2057-90$ & $04 / 90-12 / 93$ & 0.1 & Ion-exchange chromatography, OMNIPAX-500. \\
\hline & 00950 & B & $\mathrm{E}$ & $\mathrm{I}-2327-85$ & $01 / 94-10 / 00$ & 0.1 & Ion selective electrode, automated. \\
\hline & & & & & $10 / 00-09 / 01$ & 0.16 & \\
\hline \multirow[t]{3}{*}{ Silica, in $\mathrm{mg} / \mathrm{L}$} & 00955 & $\mathrm{D}$ & B & I-1472-87 & $10 / 88-04 / 90$ & 0.1 & Atomic emission spectrometry, ICP. \\
\hline & 00955 & $\mathrm{C}$ & $\mathrm{E}$ & $\mathrm{I}-2700-85$ & $04 / 90-10 / 00$ & 0.1 & Colorimetry, automated, molybdate blue. \\
\hline & & & & & $10 / 00-09 / 01$ & 0.48 & \\
\hline
\end{tabular}

\begin{tabular}{|c|c|c|c|c|c|c|c|}
\hline \multicolumn{8}{|c|}{ Physical properties and general water quality } \\
\hline Temperature in ${ }^{\circ} \mathrm{C}$ & 00010 & - & - & - & $10 / 88-09 / 01$ & 0.5 & Thermometer/thermistor. \\
\hline $\begin{array}{l}\text { Specific conductance, } \\
\text { field, in } \mu \mathrm{S} / \mathrm{cm}\end{array}$ & 00095 & - & - & - & $10 / 88-09 / 01$ & None & Electrometric, Wheatstone bridge. \\
\hline $\begin{array}{l}\text { Specific conductance, lab- } \\
\text { oratory, in } \mu \mathrm{S} / \mathrm{cm}\end{array}$ & 90095 & A & $\mathrm{E}$ & I-2781-85 & $10 / 88-09 / 01$ & 1 & Electrometric, Wheatstone bridge. \\
\hline $\mathrm{pH}$, field, in std units & 00400 & - & - & - & $10 / 88-09 / 01$ & None & Electrometric, ion-selective electrode. \\
\hline $\mathrm{pH}$, laboratory, in std units & 00403 & A & $\mathrm{E}$ & $\mathrm{I}-2587-89$ & $10 / 88-09 / 01$ & 0.1 & Electrometric, ion-selective electrode. \\
\hline $\begin{array}{l}\text { Acid neutralizing capacity } \\
(\mathrm{ANC}), \text { in } \mathrm{mg} / \mathrm{L} \text { as } \\
\mathrm{CaCO}_{3}\end{array}$ & Various & & $\mathrm{E}$ & $\mathrm{I}-2030-89$ & $10 / 88-09 / 01$ & None & Electrometric/titration to $\mathrm{pH} 4.5$. \\
\hline $\begin{array}{l}\text { Bicarbonate, in } \mathrm{mg} / \mathrm{L} \text { as } \\
\mathrm{CaCO}_{3}\end{array}$ & Various & & - & - & $10 / 88-09 / 01$ & None & Electrometric/incremental titration. \\
\hline Dissolved oxygen, in mg/L & 00300 & - & - & - & $10 / 88-09 / 01$ & 0.1 & Electrometric. \\
\hline $\begin{array}{l}\text { Total organic carbon, in } \\
\mathrm{mg} / \mathrm{L}\end{array}$ & 00680 & A & $\mathrm{F}$ & O-3100-83 & $10 / 88-09 / 01$ & 0.1 & Wet oxidation. \\
\hline Dissolved solids, in $\mathrm{mg} / \mathrm{L}$ & 70300 & A & $\mathrm{E}$ & $\mathrm{I}-1750-89$ & $\begin{array}{l}10 / 88-12 / 97 \\
12 / 97-09 / 01\end{array}$ & $\begin{array}{r}1 \\
10\end{array}$ & Evaporation at $180^{\circ} \mathrm{C}$, gravimetric. \\
\hline Color, in PCU & 00080 & A & $\mathrm{E}$ & I-1250-89 & $10 / 88-09 / 01$ & 1 & Electrometric, visual comparison. \\
\hline $\begin{array}{l}\text { Chlorophyll } a \text {, phy- } \\
\text { toplankton, in } \mu \mathrm{g} / \mathrm{L}\end{array}$ & 70953 & A & $\mathrm{F}$ & B-6530-85 & $10 / 88-09 / 01$ & 0.1 & High pressure liquid-chromatography, spectrophotometric. \\
\hline $\begin{array}{l}\text { Chlorophyll } b \text {, phy- } \\
\text { toplankton, in } \mu \mathrm{g} / \mathrm{L}\end{array}$ & 70954 & A & $\mathrm{F}$ & B-6530-85 & $10 / 88-09 / 01$ & 0.1 & High pressure liquid-chromatography, spectrophotometric. \\
\hline MBAS, in $\mathrm{mg} / \mathrm{L}$ & 38260 & A & $\mathrm{F}$ & O-3111-83 & $10 / 88-10 / 90$ & 0.01 & Colorimetry. \\
\hline $\begin{array}{l}\text { Suspended sediment, in } \\
\mathrm{mg} / \mathrm{L}\end{array}$ & 80154 & - & & & $10 / 88-10 / 01$ & 1.0 & Gravimetric. \\
\hline
\end{tabular}


Table 7. Inorganic constituents and physical properties analyzed by the U.S. Geological Survey National Water Quality Laboratory for the Triangle Area Water Supply Monitoring Project, and the methods used for sample analyses.-Continued

[USGS, U.S. Geological Survey; ID, identification; mg/L, milligram per liter; ICP, induction-coupled argon plasma; bold numbers are lowest reporting level; ${ }^{\circ} \mathrm{C}$, degree Celsius; —, not applicable; $\mu$ S/cm, micro-

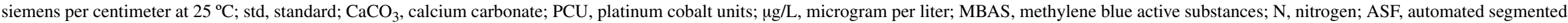
flow; P, phosphorus; OES, optical emission spectrometry; AA, atomic absorption spectrometry]

\begin{tabular}{|c|c|c|c|c|c|c|c|}
\hline Constituent & $\begin{array}{l}\text { Parameter } \\
\text { code }\end{array}$ & $\begin{array}{l}\text { Method } \\
\text { code }\end{array}$ & $\begin{array}{l}\text { Method } \\
\text { refer- } \\
\text { ence }^{a}\end{array}$ & $\begin{array}{l}\text { USGS } \\
\text { method } \\
I^{b}\end{array}$ & $\begin{array}{l}\text { Period } \\
\text { of } \\
\text { record }\end{array}$ & $\begin{array}{l}\text { Reporting } \\
\text { level }\end{array}$ & Analytical method \\
\hline \multicolumn{8}{|c|}{ Nutrients } \\
\hline \multirow{5}{*}{$\begin{array}{l}\text { Total ammonia plus } \\
\text { organic nitrogen, in } \\
\mathrm{mg} / \mathrm{L} \text { as } \mathrm{N}\end{array}$} & 00625 & A & $\mathrm{E}$ & $\mathrm{I}-4552-85$ & $10 / 88-10 / 91$ & 0.1 & Kjeldahl block digestion, salicylate-hypochlorite ASF, colorimetry. \\
\hline & 00625 & $\mathrm{C}$ & $\mathrm{G}$ & $\mathrm{I}-4515-91$ & $10 / 91-09 / 94$ & 0.2 & Micro-Kjeldahl digestion, ASF, colorimetry. \\
\hline & 00625 & $\mathrm{D}$ & $\mathrm{G}, \mathrm{I}$ & $\mathrm{I}-4515-91$ & $10 / 94-10 / 97$ & 0.2 & $\begin{array}{l}\text { Micro-Kjeldahl digestion, ASF, colorimetry, acidified, new field preser- } \\
\text { vative }\end{array}$ \\
\hline & & & & & $11 / 97-10 / 00$ & 0.1 & \\
\hline & & & & & $10 / 00-09 / 01$ & 0.08 & \\
\hline \multirow{5}{*}{$\begin{array}{l}\text { Dissolved ammonia plus } \\
\text { organic nitrogen, in } \\
\mathrm{mg} / \mathrm{L} \text { as } \mathrm{N}\end{array}$} & 00623 & A & $\mathrm{E}$ & $\mathrm{I}-2552-85$ & $10 / 88-10 / 91$ & 0.1 & Kjeldahl block digestion salicylate-hypochlorite, ASF, colorimetry. \\
\hline & 00623 & $\mathrm{C}$ & G & $\mathrm{I}-2515-91$ & $10 / 91-09 / 94$ & 0.2 & Micro-Kjeldahl digestion, ASF, colorimetry. \\
\hline & 00623 & $\mathrm{D}$ & $\mathrm{G}, \mathrm{I}$ & $\mathrm{I}-2515-91$ & $10 / 94-11 / 97$ & 0.2 & $\begin{array}{l}\text { Micro-Kjeldahl digestion, ASF, colorimetry, acidified, new field preser- } \\
\text { vative }\end{array}$ \\
\hline & & & & & $10 / 97-09 / 98$ & 0.1 & \\
\hline & & & & & $10 / 98-09 / 01$ & 0.1 & \\
\hline Total ammonia, in $\mathrm{mg} / \mathrm{L}$ & 00610 & B & $\mathrm{E}$ & $\mathrm{I}-4523-85$ & $10 / 88-09 / 92$ & 0.01 & Colorimetry, ASF, salicylate-hypochlorite (method discontinued 10/92). \\
\hline \multirow{5}{*}{$\begin{array}{l}\text { Dissolved ammonia, in } \\
\mathrm{mg} / \mathrm{L} \text { as } \mathrm{N}\end{array}$} & 00608 & B & B & $\mathrm{I}-2522-90$ & $10 / 88-10 / 94$ & 0.01 & Colorimetry, ASF, salicylate-hypochlorite. \\
\hline & 00608 & $\mathrm{~F}$ & $\mathrm{~B}, \mathrm{I}$ & $\mathrm{I}-2522-90$ & $10 / 94-11 / 97$ & 0.015 & Colorimetry, ASF, salicylate-hypochlorite, new field preservative \\
\hline & & & & & $12 / 97-10 / 00$ & 0.02 & \\
\hline & & & & & $10 / 00-09 / 01$ & 0.041 & \\
\hline & 00608 & $\mathrm{H}$ & B & $\mathrm{I}-2525-89$ & $10 / 96-09 / 01$ & 0.002 & Colorimetry, ASF, salicylate-hypochlorite, low-level. \\
\hline Total nitrite, in $\mathrm{mg} / \mathrm{L}$ as $\mathrm{N}$ & 00615 & B & $\mathrm{E}$ & $\mathrm{I}-4540-85$ & $10 / 88-09 / 92$ & 0.01 & $\begin{array}{l}\text { Colorimetry, automated segmented flow, diazotization (method discontin- } \\
\text { ued 10/92). }\end{array}$ \\
\hline \multirow{4}{*}{$\begin{array}{l}\text { Dissolved nitrite, in } \mathrm{mg} / \mathrm{L} \\
\text { as } \mathrm{N}\end{array}$} & 00613 & B & B & $\mathrm{I}-2340-90$ & $10 / 90-10 / 94$ & 0.01 & Colorimetry, diazotization, ASF. \\
\hline & 00613 & $\mathrm{~F}$ & $\mathrm{~B}, \mathrm{I}$ & $\mathrm{I}-2340-90$ & $10 / 94-09 / 00$ & 0.01 & Colorimetry, diazotization, ASF, new field preservative \\
\hline & & & & & $10 / 00-10 / 01$ & 0.006 & \\
\hline & 00613 & $\mathrm{H}$ & B & $\mathrm{I}-2542-89$ & $10 / 96-09 / 01$ & 0.001 & Colorimetry, diazotization, ASF, low-level. \\
\hline $\begin{array}{l}\text { Total nitrite plus nitrate, in } \\
\mathrm{mg} / \mathrm{L} \text { as } \mathrm{N}\end{array}$ & 00630 & B & $\mathrm{E}$ & I-4545-90 & $10 / 88-09 / 92$ & 0.1 & $\begin{array}{l}\text { Cadmium reduction-diazotization, ASF, colorimetry (method discontin- } \\
\text { ued 10/92). }\end{array}$ \\
\hline \multirow{4}{*}{$\begin{array}{l}\text { Dissolved nitrite plus } \\
\text { nitrate, in } \mathrm{mg} / \mathrm{L} \text { as } \mathrm{N}\end{array}$} & 00631 & B & B & $\mathrm{I}-2545-90$ & $10 / 88-09 / 91$ & 0.1 & Cadmium reduction-diazotization, ASF, colorimetry. \\
\hline & & & & & $10 / 91-09 / 94$ & 0.05 & \\
\hline & 00631 & $\mathrm{E}$ & $\mathrm{B}, \mathrm{I}$ & $\mathrm{I}-2545-90$ & $10 / 94-09 / 96$ & 0.05 & $\begin{array}{l}\text { Cadmium reduction-diazotization, ASF, colorimetry, new field preserva- } \\
\text { tive }\end{array}$ \\
\hline & 00631 & $\mathrm{G}$ & B & $\mathrm{I}-2546-91$ & $10 / 96-09 / 01$ & 0.005 & Cadmium reduction-diazotization, ASF, colorimetry, low-level. \\
\hline
\end{tabular}


Table 7. Inorganic constituents and physical properties analyzed by the U.S. Geological Survey National Water Quality Laboratory for the Triangle Area Water Supply Monitoring Project, and the methods used for sample analyses.-Continued

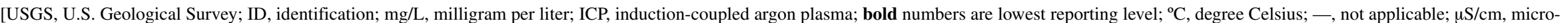

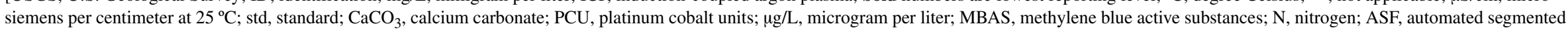
flow; P, phosphorus; OES, optical emission spectrometry; AA, atomic absorption spectrometry]

\begin{tabular}{|c|c|c|c|c|c|c|c|}
\hline Constituent & $\begin{array}{l}\text { Parameter } \\
\text { code }\end{array}$ & $\begin{array}{l}\text { Method } \\
\text { code }\end{array}$ & $\begin{array}{c}\text { Method } \\
\text { refer- } \\
\text { ence }^{\mathrm{a}}\end{array}$ & $\begin{array}{c}\text { USGS } \\
\text { method } \\
\text { ID }^{\mathrm{b}}\end{array}$ & $\begin{array}{l}\text { Period } \\
\text { of } \\
\text { record }\end{array}$ & $\begin{array}{l}\text { Reporting } \\
\text { level }\end{array}$ & Analytical method \\
\hline \multicolumn{8}{|c|}{ Nutrients (Continued) } \\
\hline \multirow{5}{*}{$\begin{array}{l}\text { Total phosphorus, in } \mathrm{mg} / \mathrm{L} \\
\text { as } \mathrm{P}\end{array}$} & 00665 & $\mathrm{~B}$ & $\mathrm{E}$ & $\mathrm{I}-4600-85$ & $10 / 88-09 / 91$ & 0.01 & Kjeldahl persulfate digestion, ascorbic acid reduction, colorimetry. \\
\hline & 00665 & $\mathrm{C}$ & $\mathrm{H}$ & $\mathrm{I}-4610-91$ & $10 / 91-09 / 94$ & 0.01 & Micro-Kjeldahl digestion, ASF, colorimetry. \\
\hline & 00665 & $\mathrm{D}$ & $\mathrm{H}, \mathrm{I}$ & I-4610-91 & $10 / 94-09 / 98$ & 0.01 & $\begin{array}{l}\text { Micro-Kjeldahl digestion, ASF, colorimetry, acidified, new field preser- } \\
\text { vative }\end{array}$ \\
\hline & & & & & $10 / 98-09 / 00$ & 0.05 & \\
\hline & & & & & $10 / 00-09 / 01$ & 0.06 & \\
\hline \multirow{3}{*}{$\begin{array}{l}\text { Dissolved phosphorus, in } \\
\mathrm{mg} / \mathrm{L} \text { as } \mathrm{P}\end{array}$} & 00666 & B & $\mathrm{E}$ & I-2600-85 & $10 / 88-09 / 91$ & 0.01 & Kjeldahl persulfate digestion, ascorbic acid reduction, colorimetry. \\
\hline & 00666 & $\mathrm{C}$ & $\mathrm{H}$ & I-2610-91 & $10 / 91-10 / 94$ & 0.01 & Micro-Kjeldahl digestion, ASF, colorimetry. \\
\hline & 00666 & $\mathrm{D}$ & $\mathrm{H}, \mathrm{I}$ & I-2610-91 & $10 / 94-09 / 96$ & 0.01 & Micro-Kjeldahl digestion, ASF, colorimetry, new field preservative \\
\hline $\begin{array}{l}\text { Total orthophosphorus, } \\
\mathrm{mg} / \mathrm{L} \text { as } \mathrm{P}\end{array}$ & 70507 & A & $\mathrm{E}$ & $\mathrm{I}-4601-85$ & $10 / 88-11 / 92$ & 0.01 & Ascorbic acid reduction, ASF, colorimetry (method discontinued 10/92). \\
\hline \multirow{4}{*}{$\begin{array}{l}\text { Dissolved orthophospho- } \\
\text { rus, in } \mathrm{mg} / \mathrm{L} \text { as } \mathrm{P}\end{array}$} & 00671 & B & B & I-2601-90 & $10 / 88-10 / 94$ & 0.01 & Colorimetry, phosphomolybdate, ASF. \\
\hline & 00671 & $\mathrm{H}$ & $\mathrm{B}, \mathrm{I}$ & I-2601-90 & $10 / 94-09 / 96$ & 0.01 & Colorimetry, phosphomolybdate, ASF, new field preservative \\
\hline & 00671 & I & $\mathrm{B}$ & I-2606-89 & $10 / 96-09 / 00$ & 0.001 & Colorimetry, phosphomolybdate, ASF, low-level. \\
\hline & & & & & $10 / 00-09 / 01$ & 0.007 & \\
\hline \multicolumn{8}{|c|}{ Metals and trace elements } \\
\hline \multirow[t]{2}{*}{ Aluminum, in $\mu \mathrm{g} / \mathrm{L}$} & 01105 & $\mathrm{C}$ & $\mathrm{E}$ & I-3054-86 & $10 / 88-12 / 98$ & 10 & Digestion, atomic emission spectrometry, direct current plasma. \\
\hline & 01105 & $\mathrm{D}$ & A & I-4471-97 & $01 / 99-09 / 01$ & 28 & AA, ICP-OES. \\
\hline \multirow[t]{3}{*}{ Arsenic, in $\mu \mathrm{g} / \mathrm{L}$} & 01002 & $\mathrm{~B}$ & $\mathrm{E}$ & $\mathrm{I}-4062-85$ & $10 / 88-09 / 98$ & 1 & Digestion, hydride generation, AA. \\
\hline & 01002 & $\mathrm{E}$ & $\mathrm{J}$ & I-4063-98 & $10 / 98-10 / 00$ & 2.6 & Digestion, graphite furnace AA. \\
\hline & & & & & $11 / 00-09 / 01$ & 1.9 & \\
\hline \multirow[t]{3}{*}{ Cadmium, in $\mu \mathrm{g} / \mathrm{L}$} & 01027B & $\mathrm{B}$ & $\mathrm{E}$ & I-3136-85 & $10 / 88-05 / 89$ & 1.0 & Digestion, chelation extraction, AA. \\
\hline & 01027 & $\mathrm{~F}$ & $\mathrm{~B}$ & I-2138-89 & $05 / 89-09 / 99$ & 1.0 & Digestion, graphite furnace, AA. \\
\hline & & & & & $10 / 99-09 / 01$ & 0.11 & \\
\hline \multirow[t]{3}{*}{ Chromium, in $\mu \mathrm{g} / \mathrm{L}$} & 01034 & $\mathrm{D}$ & $\mathrm{E}$ & I-3229-87 & $10 / 88-01 / 94$ & 1.0 & Digestion, atomic emission spectrometry, d-c plasma. \\
\hline & 01034 & $\mathrm{E}$ & $\mathrm{C}$ & I-3233-93 & $01 / 94-09 / 99$ & 1.0 & Digestion, graphite furnace, AA. \\
\hline & & & & & $10 / 99-09 / 01$ & 1.0 & \\
\hline
\end{tabular}


Table 7. Inorganic constituents and physical properties analyzed by the U.S. Geological Survey National Water Quality Laboratory for the Triangle Area Water Supply Monitoring Project, and the methods used for sample analyses.-Continued

[USGS, U.S. Geological Survey; ID, identification; mg/L, milligram per liter; ICP, induction-coupled argon plasma; bold numbers are lowest reporting level; ${ }^{\circ} \mathrm{C}$, degree Celsius; - , not applicable; $\mu$ S/cm, micro-

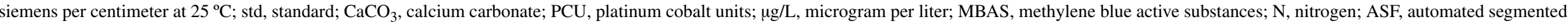
flow; P, phosphorus; OES, optical emission spectrometry; AA, atomic absorption spectrometry]

\begin{tabular}{|c|c|c|c|c|c|c|c|}
\hline Constituent & $\begin{array}{l}\text { Parameter } \\
\text { code }\end{array}$ & $\begin{array}{c}\text { Method } \\
\text { code }\end{array}$ & $\begin{array}{l}\text { Method } \\
\text { refer- } \\
\text { ence }^{a}\end{array}$ & $\begin{array}{c}\text { USGS } \\
\text { method } \\
\text { ID }^{\mathrm{b}}\end{array}$ & $\begin{array}{l}\text { Period } \\
\text { of } \\
\text { record }\end{array}$ & $\begin{array}{c}\text { Reporting } \\
\text { level }\end{array}$ & Analytical method \\
\hline \multicolumn{8}{|c|}{ Metals and trace elements (Continued) } \\
\hline \multirow[t]{5}{*}{ Cobalt, in $\mu \mathrm{g} / \mathrm{L}$} & 01037 & B & $\mathrm{E}$ & $\mathrm{I}-3240-85$ & $10 / 88-05 / 89$ & 1.0 & Digestion, chelation extraction, AA. \\
\hline & 01037 & $\mathrm{~F}$ & $\mathrm{~B}$ & I-4243-89 & $05 / 89-09 / 99$ & 1.0 & Digestion, graphite furnace, AA. \\
\hline & & & & & $10 / 99-09 / 00$ & 1.8 & \\
\hline & & & & & $10 / 00-05 / 01$ & 2.4 & \\
\hline & & & & & $05 / 01-09 / 01$ & 1.8 & \\
\hline \multirow[t]{5}{*}{ Copper, in $\mu \mathrm{g} / \mathrm{L}$} & 01042 & $\mathrm{~B}$ & $\mathrm{E}$ & I-3271-85 & $10 / 88-5 / 89$ & 1.0 & Digestion, chelation extraction, AA. \\
\hline & 01042 & $\mathrm{~F}$ & $\mathrm{~B}$ & I-4274-89 & $6 / 89-9 / 99$ & 1.0 & Digestion, graphite furnace, AA. \\
\hline & & & & & $10 / 99-9 / 00$ & 1.2 & \\
\hline & & & & & $10 / 00-5 / 01$ & 1.8 & \\
\hline & & & & & $5 / 01-9 / 01$ & 1.2 & \\
\hline \multirow[t]{2}{*}{ Iron, in $\mu \mathrm{g} / \mathrm{L}$} & 01045 & $\mathrm{~B}$ & $\mathrm{E}$ & I-3381-85 & $11 / 88-11 / 98$ & 10 & Digestion, direct aspiration, AA. \\
\hline & 01045 & $\mathrm{C}$ & A & I-4471-97 & $3 / 99-9 / 01$ & 14 & Atomic emission spectrometry, ICP-OES. \\
\hline \multirow[t]{3}{*}{ Lead, in $\mu \mathrm{g} / \mathrm{L}$} & 01051 & $\mathrm{~B}$ & $\mathrm{E}$ & $\mathrm{I}-3400-85$ & $10 / 88-5 / 89$ & 5.0 & Digestion, chelation extraction, AA. \\
\hline & 01051 & $\mathrm{~F}$ & $\mathrm{~B}$ & I-4403-89 & $5 / 89-9 / 99$ & 1 & Digestion, graphite furnace, AA. \\
\hline & & & & & $10 / 99-9 / 01$ & 1 & \\
\hline \multirow[t]{3}{*}{ Manganese, in $\mu \mathrm{g} / \mathrm{L}$} & 01055 & A & $\mathrm{E}$ & I-3454-85 & $11 / 88-11 / 98$ & 10 & Digestion, direct aspiration, AA. \\
\hline & 01055 & $\mathrm{D}$ & A & I-4471-97 & $3 / 99-9 / 99$ & 3 & Atomic emission spectrometric, ICP-OES. \\
\hline & & & & & $10 / 99-9 / 01$ & 2.8 & \\
\hline \multirow[t]{4}{*}{ Mercury, in $\mu \mathrm{g} / \mathrm{L}$} & 71900 & $\mathrm{~B}$ & $\mathrm{E}$ & $\mathrm{I}-3462-85$ & $10 / 88-9 / 99$ & 0.1 & Cold vapor, flameless, AA. \\
\hline & & & & & $10 / 99-10 / 00$ & 0.3 & \\
\hline & & & & & $10 / 00-3 / 01$ & 0.14 & \\
\hline & 71900 & $\mathrm{D}$ & $\mathrm{K}$ & I-4464-01 & $4 / 01-9 / 01$ & 0.01 & Cold vapor, atomic fluorescence. \\
\hline \multirow[t]{3}{*}{ Molybdenum, in $\mu \mathrm{g} / \mathrm{L}$} & 01062 & A & $\mathrm{E}$ & $\mathrm{I}-3490-85$ & $11 / 88-10 / 94$ & 1.0 & Digestion, chelation extraction, flame, AA. \\
\hline & 01062 & $\mathrm{~B}$ & $\mathrm{~L}$ & I-3492-96 & $11 / 94-10 / 00$ & 1.0 & Digestion, graphite furnace, AA. \\
\hline & & & & & $10 / 00-9 / 01$ & 1.5 & \\
\hline \multirow[t]{3}{*}{ Nickel, in $\mu \mathrm{g} / \mathrm{L}$} & 01067 & $\mathrm{~B}$ & $\mathrm{E}$ & $\mathrm{I}-3500-85$ & $10 / 88-5 / 89$ & 1.0 & Digestion, chelation extraction, AA. \\
\hline & 01067 & $\mathrm{~F}$ & $\mathrm{~B}$ & I-4503-89 & $5 / 89-9 / 99$ & 1.0 & Digestion, graphite furnace, AA. \\
\hline & & & & & $10 / 99-9 / 01$ & 1.8 & \\
\hline
\end{tabular}


Table 7. Inorganic constituents and physical properties analyzed by the U.S. Geological Survey National Water Quality Laboratory for the Triangle Area Water Supply Monitoring Project, and the methods used for sample analyses.-Continued

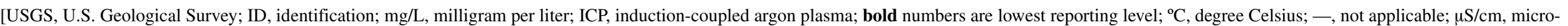

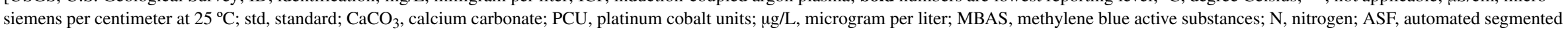
flow; P, phosphorus; OES, optical emission spectrometry; AA, atomic absorption spectrometry]

\begin{tabular}{|c|c|c|c|c|c|c|c|}
\hline Constituent & $\begin{array}{l}\text { Parameter } \\
\text { code }\end{array}$ & $\begin{array}{l}\text { Method } \\
\text { code }\end{array}$ & $\begin{array}{l}\text { Method } \\
\text { refer- } \\
\text { ence }^{a}\end{array}$ & $\begin{array}{c}\text { USGS } \\
\text { method } \\
\text { ID }^{b}\end{array}$ & $\begin{array}{l}\text { Period } \\
\text { of } \\
\text { record }\end{array}$ & $\begin{array}{c}\text { Reporting } \\
\text { level }\end{array}$ & Analytical method \\
\hline \multicolumn{8}{|c|}{ Metals and trace elements (Continued) } \\
\hline \multirow[t]{3}{*}{ Selenium, in $\mu \mathrm{g} / \mathrm{L}$} & 01147 & $\mathrm{~A}$ & $\mathrm{E}$ & $\mathrm{I}-4667-85$ & $11 / 88-9 / 98$ & 1.0 & Digestion, hydride conversion, AA. \\
\hline & 01147 & $\mathrm{D}$ & $\mathrm{J}$ & $\mathrm{I}-4668-98$ & $10 / 98-9 / 99$ & 1.0 & Digestion, graphite furnace, AA. \\
\hline & & & & & $10 / 99-9 / 01$ & 2.6 & \\
\hline \multirow[t]{3}{*}{ Silver, in $\mu \mathrm{g} / \mathrm{L}$} & 01077 & B & $\mathrm{E}$ & $\mathrm{I}-3720-85$ & $10 / 88-5 / 89$ & 1.0 & Digestion, chelation extraction, AA. \\
\hline & 01077 & $\mathrm{~F}$ & $\mathrm{~B}$ & I-4724-89 & $5 / 89-10 / 00$ & 1.0 & Digestion, graphite furnace, AA. \\
\hline & & & & & $10 / 00-9 / 01$ & 0.43 & \\
\hline \multirow[t]{3}{*}{ Zinc, in $\mu \mathrm{g} / \mathrm{L}$} & 01092 & A & $\mathrm{E}$ & $\mathrm{I}-3900-85$ & $11 / 88-11 / 98$ & 10 & Digestion, direct aspiration, AA. \\
\hline & 01092 & $\mathrm{C}$ & A & $\mathrm{I}-4471-97$ & $12 / 98-9 / 99$ & 40 & Digestion, atomic emission spectrometric, ICP-OES. \\
\hline & & & & & $10 / 99-9 / 01$ & 31 & \\
\hline
\end{tabular}

${ }^{a}$ Method references: (A) Garbarino and Struzeski, 1998; (B) Fishman, 1993; (C) McLain, 1993; (D) Faires, 1993; (E) Fishman and Friedman, 1989; (F) Wershaw and others, 1987; (G) Patton and Truitt, 2000; (H) Patton and Truitt, 1992; (I) U.S. Geological Survey, 1994; (J) Jones and Garbarino, 1999; (K) Garbarino and Damrau, 2001 ; (L) Jones and McLain, 1997.

${ }^{\mathrm{b}}$ USGS analytical method identification number. 
Table 8. Synthetic organic constituents analyzed by the U.S. Geological Survey National Water Quality Laboratory for the Triangle Area Water Supply Monitoring Project, and the methods used for sample analysis.

[ $\mu \mathrm{g} / \mathrm{L}$, microgram per liter; GC/MS, gas chromatography/mass spectrometry; P\&T-GC/MS, purge and trap gas chromatography/mass spectrometry; PCNs, polychlorinated naphthalenes; PCBs, polychlorinated biphenyls; GC/ECD, gas chromatography/electron-capture detector; GC/FPD, gas chromatography/flamephotometric detector; - , not applicable]

\begin{tabular}{|c|c|c|c|c|c|c|}
\hline $\begin{array}{l}\text { Class of organic } \\
\text { compound }\end{array}$ & $\begin{array}{l}\text { Method reference } \\
\text { and notes }\end{array}$ & Constituent name & $\begin{array}{l}\text { Parameter } \\
\text { code }\end{array}$ & $\begin{array}{l}\text { Method } \\
\text { code }\end{array}$ & $\begin{array}{l}\text { Analytical } \\
\text { methods }\end{array}$ & $\begin{array}{c}\text { Reporting } \\
\text { level, in } \mu \mathrm{g} / \mathrm{L}\end{array}$ \\
\hline \multirow{32}{*}{$\begin{array}{l}\text { Acid and base/ } \\
\text { neutral extract- } \\
\text { able semi- } \\
\text { volatile organic } \\
\text { compounds }\end{array}$} & \multirow{32}{*}{$\begin{array}{l}\text { O-3116-87 (Fishman, 1993). } \\
\text { Sampled three times per } \\
\text { year during 1989-90 water } \\
\text { years; used as a follow-up } \\
\text { analysis after } 1990 \text { for } \\
\text { selected samples scanned } \\
\text { using gas chromatography/ } \\
\text { flame ionization detector } \\
\text { (GC/FID) }\end{array}$} & Acenaphthylene & 34200 & A & GC/MS & 5 \\
\hline & & Anthracene & 34220 & A & GC/MS & 5 \\
\hline & & Benzo(B)fluoranthene & 34230 & A & GC/MS & 10 \\
\hline & & Benzo(K)fluoranthene & 34242 & A & GC/MS & 10 \\
\hline & & bis 2-chloroethyl ether & 34273 & A & GC/MS & 5 \\
\hline & & bis (2-chloroethoxy) methane & 34278 & A & GC/MS & 5 \\
\hline & & bis (2-chloroisopropyl) ether & 34283 & A & GC/MS & 5 \\
\hline & & N-butylbenzylphthalate & 34292 & A & GC/MS & \\
\hline & & Chrysene & 34320 & A & GC/MS & \\
\hline & & Fluorene & 34381 & A & GC/MS & \\
\hline & & Hexachlorocyclopentadiene & 34386 & A & GC/MS & \\
\hline & & Hexachloroethane & 34396 & A & GC/MS & \\
\hline & & Indeno(1,2,3-cd)pyrene & 34403 & A & GC/MS & 10 \\
\hline & & Isophorone & 34408 & A & GC/MS & 5 \\
\hline & & N-nitrosodi-N-propylamine & 34428 & A & GC/MS & 5 \\
\hline & & N-Nitrosodiphenylamine & 34433 & A & GC/MS & 5 \\
\hline & & N-nitrosodimethylamine & 34438 & A & GC/MS & 5 \\
\hline & & Nitrobenzene & 34447 & A & GC/MS & 5 \\
\hline & & para chlorometa cresol & & & GC/MS & 30 \\
\hline & & $(1,2-5,6)$ Dibenzanthracene & 34556 & A & GC/MS & 10 \\
\hline & & 1,3-Dichlorobenzene & 34566 & A & GC/MS & 5 \\
\hline & & 1,4-Dichlorobenzene & 34571 & A & GC/MS & 5 \\
\hline & & 2-Chloronaphthalene & 34581 & A & GC/MS & 5 \\
\hline & & 2-Chlorophenol & 34586 & A & GC/MS & 5 \\
\hline & & 2-Nitrophenol & 34591 & A & GC/MS & 5 \\
\hline & & Di-N-octylphthalate & 34596 & A & GC/MS & 10 \\
\hline & & 2,4-Dichlorophenol & 34601 & A & GC/MS & 5 \\
\hline & & 2,4-Dimethylphenol & 34606 & A & GC/MS & 5 \\
\hline & & 2,4-Dinitrotoluene & 34611 & A & GC/MS & 5 \\
\hline & & 2,4-Dinitrophenol & 34616 & A & GC/MS & 20 \\
\hline & & 2,4,6-Trichlorophenol & 34621 & A & GC/MS & 20 \\
\hline & & 2,6-Dinitrotoluene & 34626 & A & GC/MS & 5 \\
\hline
\end{tabular}


Table 8. Synthetic organic constituents analyzed by the U.S. Geological Survey National Water Quality Laboratory for the Triangle Area Water Supply Monitoring Project, and the methods used for sample analysis. - Continued

[ $\mu \mathrm{g} / \mathrm{L}$, microgram per liter; GC/MS, gas chromatography/mass spectrometry; P\&T-GC/MS, purge and trap gas chromatography/mass spectrometry; PCNs, polychlorinated naphthalenes; PCBs, polychlorinated biphenyls; GC/ECD, gas chromatography/electron-capture detector; GC/FPD, gas chromatography/flamephotometric detector; - , not applicable]

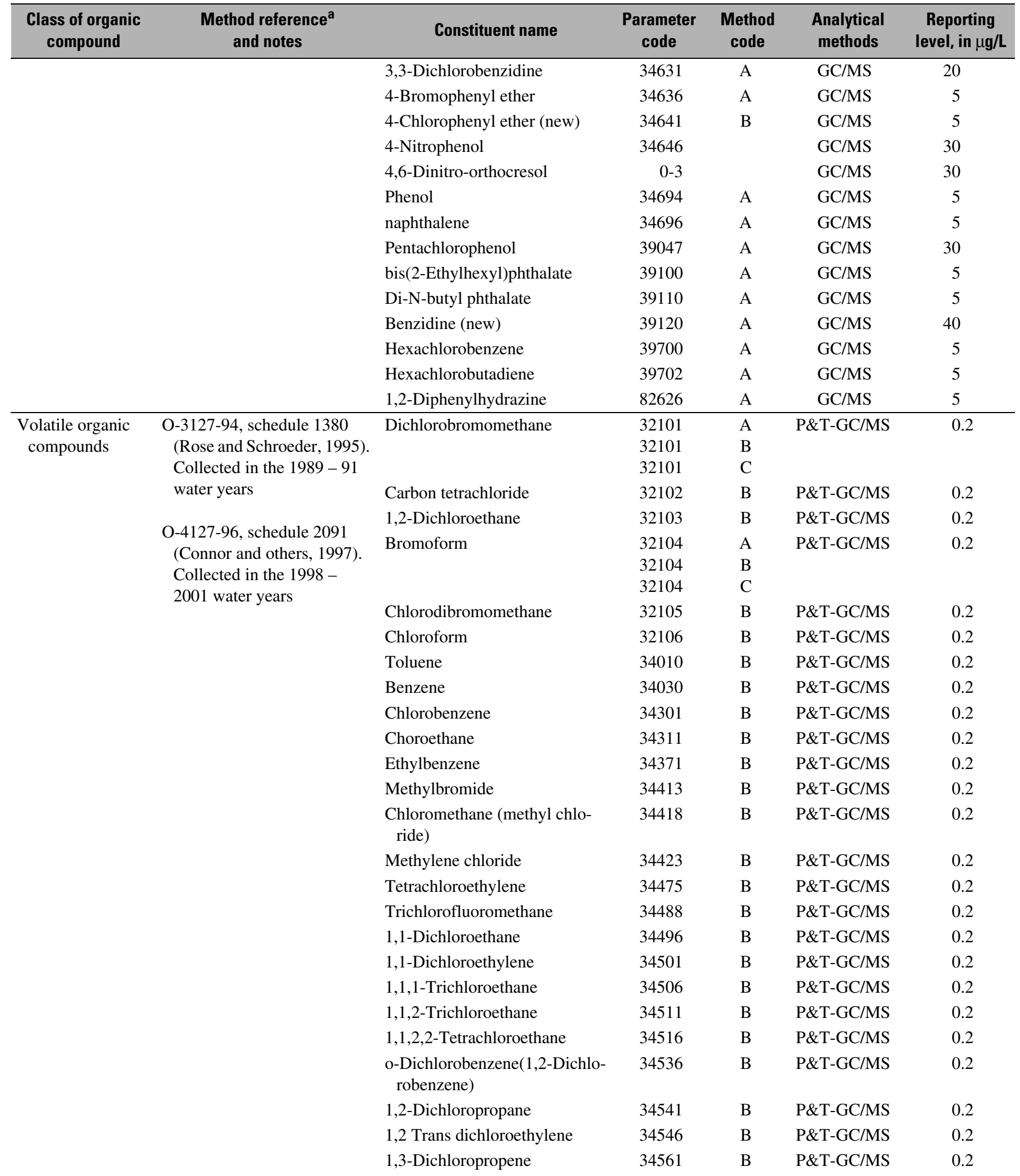


Table 8. Synthetic organic constituents analyzed by the U.S. Geological Survey National Water Quality Laboratory for the Triangle Area Water Supply Monitoring Project, and the methods used for sample analysis.—Continued

[ $\mu \mathrm{g} / \mathrm{L}$, microgram per liter; GC/MS, gas chromatography/mass spectrometry; P\&T-GC/MS, purge and trap gas chromatography/mass spectrometry; PCNs, polychlorinated naphthalenes; PCBs, polychlorinated biphenyls; GC/ECD, gas chromatography/electron-capture detector; GC/FPD, gas chromatography/flamephotometric detector; - , not applicable]




Table 8. Synthetic organic constituents analyzed by the U.S. Geological Survey National Water Quality Laboratory for the Triangle Area Water Supply Monitoring Project, and the methods used for sample analysis. - Continued

[ $\mu \mathrm{g} / \mathrm{L}$, microgram per liter; GC/MS, gas chromatography/mass spectrometry; P\&T-GC/MS, purge and trap gas chromatography/mass spectrometry; PCNs, polychlorinated naphthalenes; PCBs, polychlorinated biphenyls; GC/ECD, gas chromatography/electron-capture detector; GC/FPD, gas chromatography/flamephotometric detector; - , not applicable]

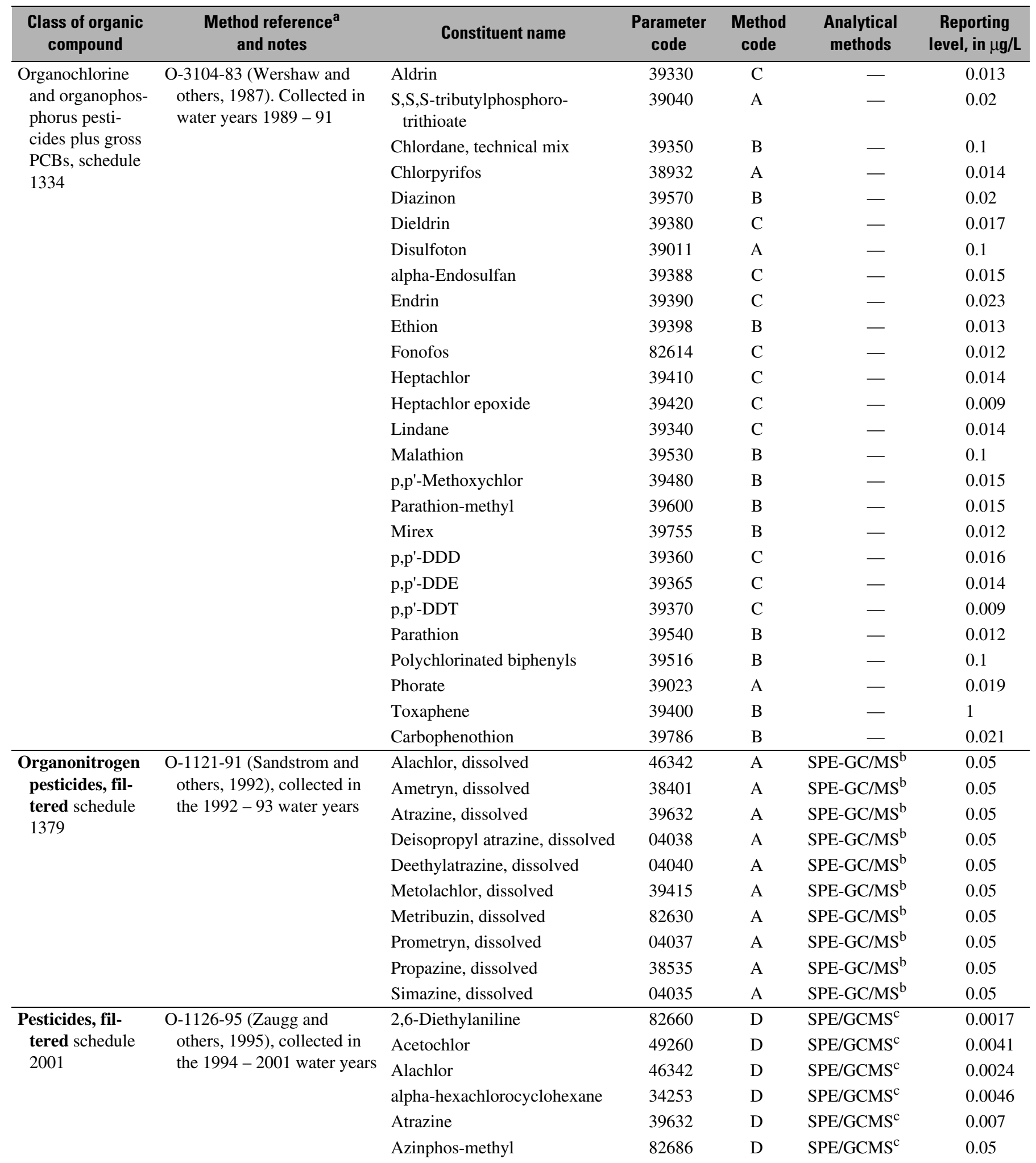


Table 8. Synthetic organic constituents analyzed by the U.S. Geological Survey National Water Quality Laboratory for the Triangle Area Water Supply Monitoring Project, and the methods used for sample analysis.—Continued

[ $\mu \mathrm{g} / \mathrm{L}$, microgram per liter; GC/MS, gas chromatography/mass spectrometry; P\&T-GC/MS, purge and trap gas chromatography/mass spectrometry; PCNs, polychlorinated naphthalenes; PCBs, polychlorinated biphenyls; GC/ECD, gas chromatography/electron-capture detector; GC/FPD, gas chromatography/flamephotometric detector; —, not applicable]

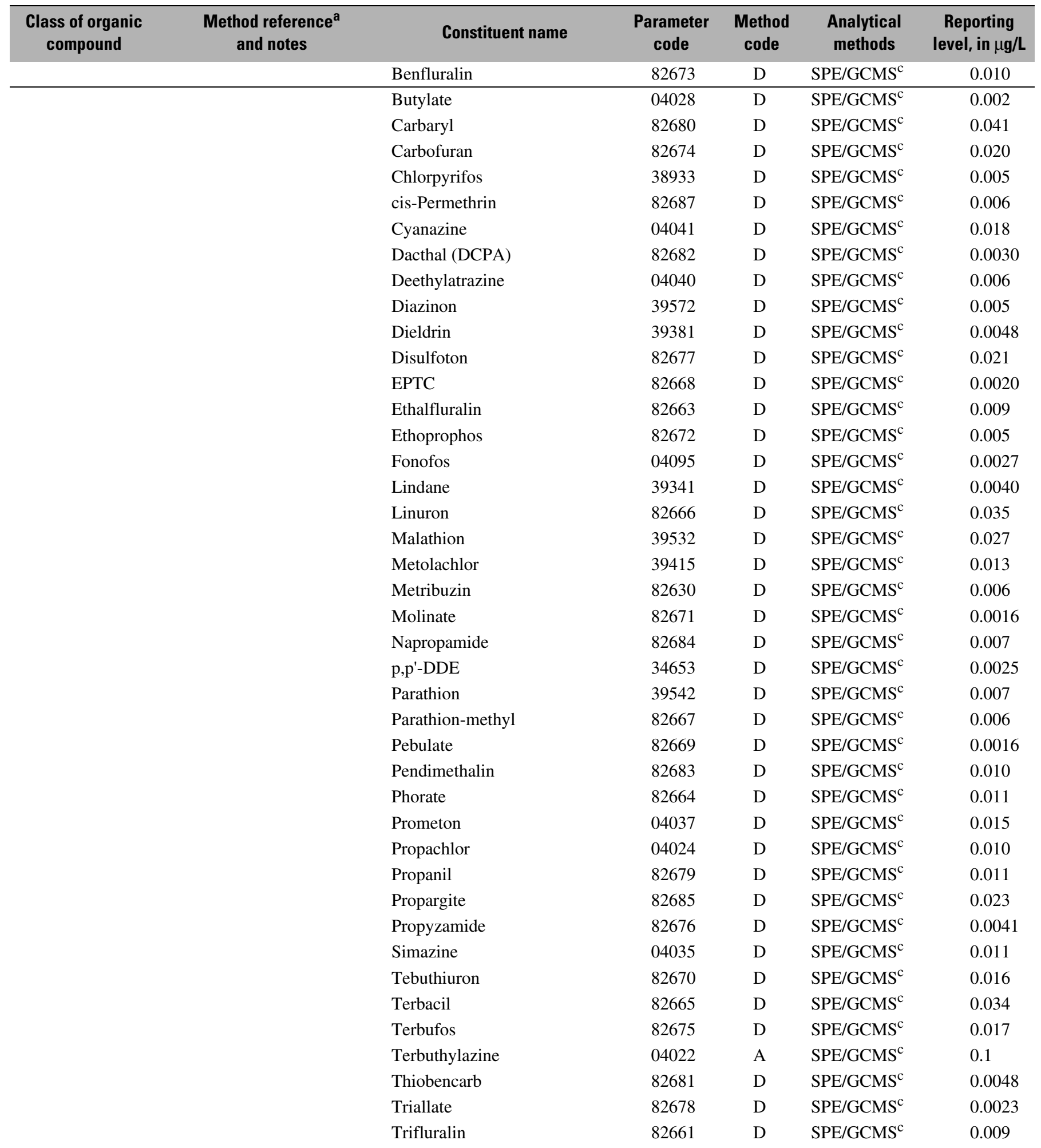


Table 8. Synthetic organic constituents analyzed by the U.S. Geological Survey National Water Quality Laboratory for the Triangle Area Water Supply Monitoring Project, and the methods used for sample analysis. - Continued

[ $\mu \mathrm{g} / \mathrm{L}$, microgram per liter; GC/MS, gas chromatography/mass spectrometry; P\&T-GC/MS, purge and trap gas chromatography/mass spectrometry; PCNs, polychlorinated naphthalenes; PCBs, polychlorinated biphenyls; GC/ECD, gas chromatography/electron-capture detector; GC/FPD, gas chromatography/flamephotometric detector; - , not applicable]

\begin{tabular}{|c|c|c|c|c|c|c|}
\hline $\begin{array}{l}\text { Class of organic } \\
\text { compound }\end{array}$ & $\begin{array}{l}\text { Method reference }{ }^{\mathrm{a}} \\
\text { and notes }\end{array}$ & Constituent name & $\begin{array}{l}\text { Parameter } \\
\text { code }\end{array}$ & $\begin{array}{l}\text { Method } \\
\text { code }\end{array}$ & $\begin{array}{l}\text { Analytical } \\
\text { methods }\end{array}$ & $\begin{array}{c}\text { Reporting } \\
\text { level, in } \mu \mathrm{g} / \mathrm{L}\end{array}$ \\
\hline \multirow{29}{*}{$\begin{array}{l}\text { Pesticides, } \\
\text { filtered } \\
\text { schedule } 2050\end{array}$} & \multirow{29}{*}{$\begin{array}{l}\text { O-1131-95 (Werner and } \\
\text { others, 1996) collected in } \\
\text { the } 1994-2001 \text { water years }\end{array}$} & $2,4,5-\mathrm{T}$ & 39742 & $\mathrm{~B}$ & SPE-HPLC $^{\mathrm{d}}$ & - \\
\hline & & $2,4-\mathrm{D}$ & 39732 & $\mathrm{~B}$ & SPE-HPLC ${ }^{\mathrm{d}}$ & - \\
\hline & & $2,4-\mathrm{DB}$ & 38746 & A & SPE-HPLC ${ }^{\mathrm{d}}$ & - \\
\hline & & Silvex & 39762 & B & SPE-HPLC ${ }^{\mathrm{d}}$ & - \\
\hline & & 3-Hydroxycarbofuran & 49308 & A & SPE-HPLC ${ }^{\mathrm{d}}$ & - \\
\hline & & Acifluorfen & 49315 & $\mathrm{~A}$ & SPE-HPLC ${ }^{\mathrm{d}}$ & - \\
\hline & & Aldicarb & 49312 & A & SPE-HPLC ${ }^{\mathrm{d}}$ & - \\
\hline & & Aldicarb sulfone & 49313 & A & SPE-HPLC ${ }^{\mathrm{d}}$ & - \\
\hline & & Aldicarb sulfoxide & 49314 & A & SPE-HPLC ${ }^{\mathrm{d}}$ & - \\
\hline & & Carbaryl & 49310 & A & SPE-HPLC ${ }^{\mathrm{d}}$ & - \\
\hline & & Carbofuran & 49309 & A & SPE-HPLC ${ }^{\mathrm{d}}$ & - \\
\hline & & Chloramben, methyl ester & 49307 & A & SPE-HPLC $^{\mathrm{d}}$ & - \\
\hline & & Chlorothalonil & 49306 & A & SPE-HPLC ${ }^{\mathrm{d}}$ & - \\
\hline & & Clopyralid & 49305 & A & SPE-HPLC ${ }^{\mathrm{d}}$ & - \\
\hline & & Dacthal monoacid & 49304 & A & SPE-HPLC ${ }^{\mathrm{d}}$ & - \\
\hline & & Dicamba & 38442 & A & SPE-HPLC $^{\mathrm{d}}$ & - \\
\hline & & Dichlobenil & 49303 & A & SPE-HPLC ${ }^{\mathrm{d}}$ & - \\
\hline & & Dichlorprop & 49302 & A & SPE-HPLC ${ }^{\mathrm{d}}$ & - \\
\hline & & Dinoseb & 49301 & A & SPE-HPLC ${ }^{\mathrm{d}}$ & - \\
\hline & & Methiocarb & 38501 & A & SPE-HPLC $^{\mathrm{d}}$ & - \\
\hline & & Methomyl & 49296 & A & SPE-HPLC $^{\mathrm{d}}$ & - \\
\hline & & Neburon & 49294 & A & SPE-HPLC ${ }^{\mathrm{d}}$ & - \\
\hline & & Norflurazon & 49293 & A & SPE-HPLC ${ }^{\mathrm{d}}$ & - \\
\hline & & Oryzalin & 49292 & A & SPE-HPLC $^{\mathrm{d}}$ & - \\
\hline & & Oxamyl & 38866 & A & SPE-HPLC $^{\mathrm{d}}$ & - \\
\hline & & Picloram & 49291 & A & SPE-HPLC $^{\mathrm{d}}$ & - \\
\hline & & Propham & 49236 & A & SPE-HPLC ${ }^{\mathrm{d}}$ & - \\
\hline & & Propoxur & 38538 & A & SPE-HPLC $^{\mathrm{d}}$ & - \\
\hline & & Triclopyr & 39235 & A & SPE-HPLC ${ }^{\mathrm{d}}$ & - \\
\hline
\end{tabular}

${ }^{\mathrm{a}}$ U.S. Geological Survey analytical method reference code.

${ }^{\mathrm{b}}$ Solid-phase extraction and GC/MS with selective ion monitoring.

${ }^{\mathrm{c}} \mathrm{C}-18$ solid-phase extraction and capillary-column GC/MS.

${ }^{\mathrm{d}}$ Carbopak-B solid-phase extraction; high-performance liquid chromatography. 